\title{
Is Gutta-Percha Still the "Gold Standard" among Filling Materials in Endodontic Treatment?
}

\author{
Joanna Dobrzańska ${ }^{1,2}$, Lech B. Dobrzański ${ }^{1,2}$, Leszek A. Dobrzański ${ }^{1, *} \mathbb{C}$, Klaudiusz Gołombek ${ }^{3}$ \\ and Anna D. Dobrzańska-Danikiewicz ${ }^{4}$
}

1 Medical and Dental Engineering Centre for Research, Design and Production ASKLEPIOS, 12/1 King Jan III Sobieski St., 44-100 Gliwice, Poland; joanna.dobrzanska@centrumasklepios.pl (J.D.); dobrzanski@centrumasklepios.pl (L.B.D.)

2 Medical and Dental Centre SOBIESKI, 12/1 King Jan III Sobieski St., 44-100 Gliwice, Poland

3 Faculty of Mechanical Engineering, Silesian University of Technology, 18 A S. Konarski St., 44-100 Gliwice, Poland; klaudiusz.golombek@polsl.pl

4 Faculty of Mechanical Engineering, University of Zielona Góra, 4 Prof. Z. Szafran St., 65-516 Zielona Góra, Poland; anna.dobrzanska.danikiewicz@gmail.com

* Correspondence: leszek.dobrzanski@centrumasklepios.pl

Citation: Dobrzańska, J.; Dobrzański, L.B.; Dobrzański, L.A.; Gołombek, K.; Dobrzańska-Danikiewicz, A.D. Is Gutta-Percha Still the "Gold Standard" among Filling Materials in Endodontic Treatment? Processes 2021, 9, 1467. https://doi.org/ $10.3390 /$ pr9081467

Academic Editor: Anil K. Bhowmick

Received: 14 July 2021

Accepted: 16 August 2021

Published: 23 August 2021

Publisher's Note: MDPI stays neutral with regard to jurisdictional claims in published maps and institutional affiliations.

Copyright: (C) 2021 by the authors. Licensee MDPI, Basel, Switzerland. This article is an open access article distributed under the terms and conditions of the Creative Commons Attribution (CC BY) license (https:/ / creativecommons.org/licenses/by/ $4.0 /)$.
Abstract: The paper is an extensive monographic review of the literature, and also uses the results of the authors' own experimental research illustrating the noticed developmental tendencies of the filling material based on gutta-percha. The whole body of literature proves the correctness of the research thesis that this material is the best currently that can be used in endodontics. Caries is one of the most common global infectious diseases. Since the dawn of humankind, the consequence of the disease has been the loss of dentition over time through dental extractions. Both tooth caries and tooth loss cause numerous complications and systemic diseases, which have a serious impact on insurance systems and on the well-being, quality, and length of human life. Endodontic treatment, which has been developing since 1836, is an alternative to tooth extraction. Based on an extensive literature review, the methodology of qualifying patients for endodontic treatment was analyzed. The importance of selecting filling material and techniques for the development and obturation of the root canal during endodontic treatment was described. Particular attention was paid to the materials science aspects and the sequence of phase transformations and precipitation processes, as well as the need to ensure the stoichiometric chemical composition of $\mathrm{Ni}-\mathrm{Ti}$ alloys, and the vacuum metallurgical processes and material processing technologies for the effects of shape memory and superelasticity, which determine the suitability of tools made of this alloy for endodontic purposes. The phenomena accompanying the sterilization of such tools, limiting the relatively small number of times of their use, play an important role. The methods of root canal preparation and obturation methods through cold side condensation and thermoplastic methods, including the most modern of them, the thermo-hydraulic condensation (THC) technique, were analyzed. An important element of the research hypothesis was to prove the assumption that to optimize the technology of development and obturation of root canals, tests of filling effectiveness are identified by the density and size of the gaps between the root canal wall, and the filling methods used and devices appropriate for material research, using mainly microscopy such as light stereoscopic (LSM) and scanning electron (SEM). The most beneficial preparations were obtained by making a longitudinal breakthrough of 48 natural human teeth, extracted for medical reasons, different from caries, with compliance with all ethical principles in this field. The teeth were prepared using various methods and filled with multiple obturation techniques, using a virtual selection of experimental variants. The breakthroughs were made in liquid nitrogen after a one-sided incision with a narrow gap created by a diamond disc using a materialographic cutter. The best effectiveness of the root canal filling was ensured by the technology of preparing the root canals with K3 rotary nitinol tools and filling the teeth with the THC thermoplastic method using the System B and Obtura III devices with studs and pellets of filling material based on gutta-percha after covering the root canal walls with a thin layer of AH Plus sealant. In this way, the research thesis was confirmed. 
Keywords: dentistry; endodontics; filling materials; gutta-percha; sealants; obturation; cold side condensation; thermoplastic obturation; thermo-hydraulic condensation technique; scanning electron microscope; laser stereoscopic microscope

\section{Introduction on the Modern Stage of Sustainable Development of Dentistry}

Globally, the most common of all infectious diseases is tooth caries, affecting 3-5 billion people [1]. Humanity has been struggling with this disease since the dawn of time, and for a very long time, it has been counteracted almost exclusively by removing teeth affected by caries [2-6]. There are interactions between bacterial biofilm and the surface of the teeth, the saliva, and carbohydrates in the diet, especially sugars and starch, which, together with behavioural, social, and psychological factors, are responsible for the course and development of caries [7-9]. As in any system of natural fluids in nature, a biofilm is formed [10]; in this case, on the surfaces of the teeth. As in any natural environment, macromolecules and micro-organisms have a strong tendency to bind to the surface and form adherent microbial groups. These processes take place in an analogous sequence, regardless of the different structure and organization of biofilms and the composition and activity of the micro-organisms that form them, colonizing in different environments [11]. These steps include film conditioning deposition, adhesion and colonization of planktonic micro-organisms in the polymer matrix, adhesion of other organisms, and the separation of micro-organisms from the biofilm into the environment (Figure 1).

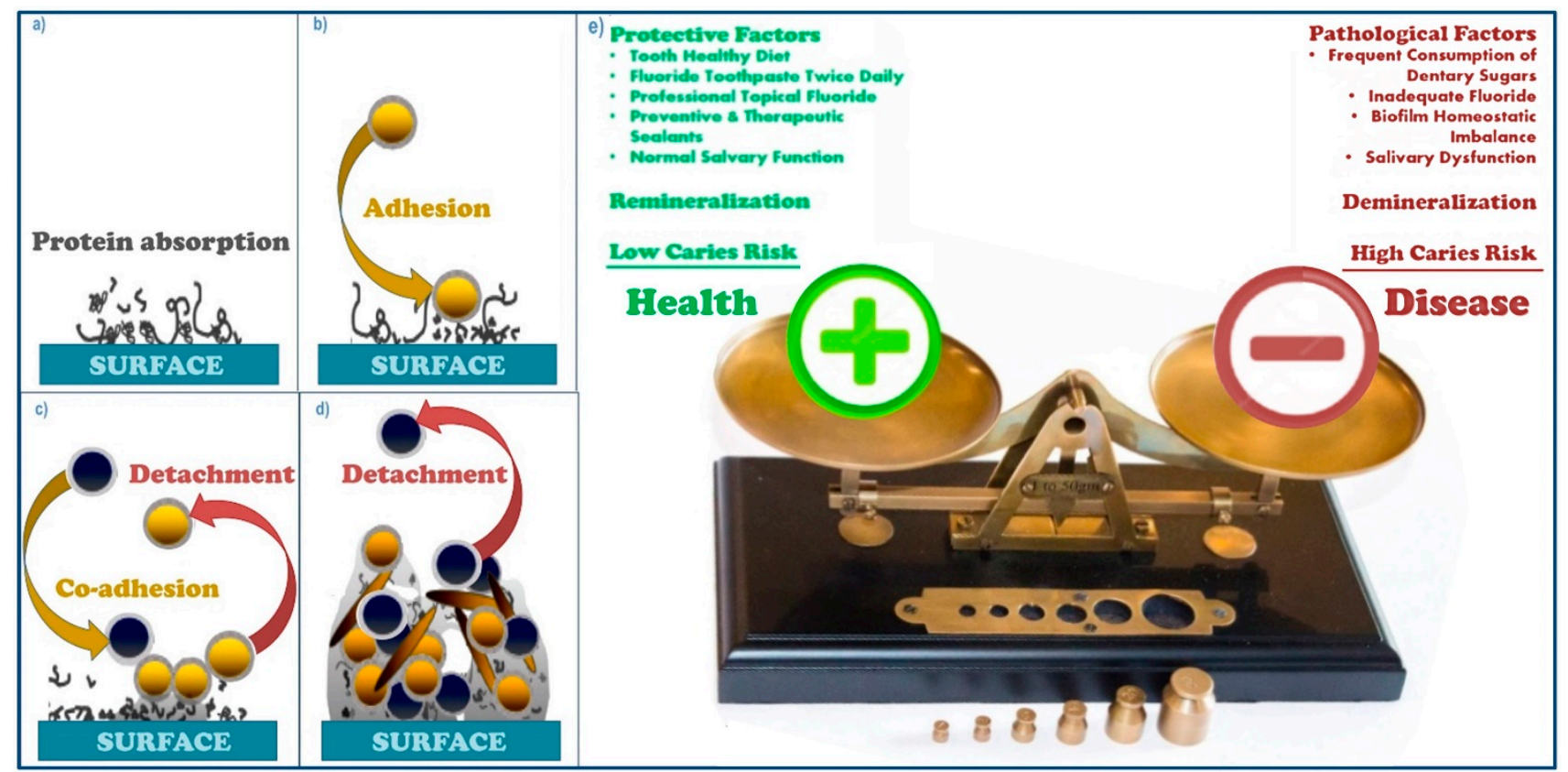

Figure 1. (a-d) Scheme of stages of bacterial biofilm formation: (a) adsorption of proteins forming a conditioning film; (b) adhesion of planktonic bacteria; (c) adhesion and detachment of planktonic bacteria; (d) growth and metabolism by adherent bacteria. (e) The dynamics of interactions between protective and pathological factors that can shift the balance in the oral cavity towards health or disease.

The balance of these processes does not cause disease states unless it is disturbed for some reason. The dynamic balance between the health or disease condition of the oral cavity or on individual teeth depends on the dynamics of the interaction between two opposing processes of demineralization and remineralization, and consists of the dynamic balance of the tooth surface with the local environment of the oral cavity [12-17]. Tooth surface demineralisation occurs due to sugar metabolism, resulting in the formation of 
lactic acid and other organic acids, which lowers the $\mathrm{pH}[18,19]$. The more this process progresses, especially below $\mathrm{pH}=5.5$, but in conjunction with the concentration of fluoride, calcium, and phosphate ions [20], the stronger the demineralization. The process consists of dissolving hydroxyapatite as the mineral phase of the tooth and diffusing its components outside the tooth [12]. The rate of demineralization depends on the extent of the diffusion of mineral ions beyond the tooth [21]. It is lower on the surface than in the subsurface enamel. This causes the so-called "white spot" on the surface of the enamel without cavitation, which is a symptom of the subclinical course of caries. Due to the differences in $\mathrm{pH}$ in different places, demineralization acts may occur locally. Demineralization is the direct cause of caries. A higher critical $\mathrm{pH}$ of 6 occurs in dentin. The reverse processes of remineralization may also take place, associated with the redeposition of calcium [22,23], sodium [24], and phosphate [25] ions, which occurs in the presence of fluoride ions [25-29]. Susceptibility to caries is lower because fluorapatite in enamel requires a much lower $\mathrm{pH}$ of 4.5 to dissolve, and therefore has a much lower solubility than hydroxyapatite [30]. The balance of demineralization and remineralization processes related to the activity of fluoride may counteract or slow down the course of caries, while in the case of the predominance of demineralization, advanced symptoms of the disease, including cavitation, occur [30,31].

External factors, including bacterial, mechanical, thermal, electrical, and chemical factors, often cause pulp inflammation and necrosis [32,33]. Infection can also occur intrinsically due to metabolic disorders, nutritional deficiencies, anemia, or bacterial diseases, as well as the participation of blood vessels penetrating the pulp through the apical foramen [34]. Exposure of dentinal tubules may be caused by pathological factors, such as cavities of carious and non-carious origin, and by iatrogenic factors; i.e., caused unintentionally during medical procedures performed by a dentist. The most common extrinsic factors contributing to the development of pulp diseases are micro-organisms that penetrate through the exposed dentinal tubules from the tooth crown and the lateral tubules and apical opening from the side of the damaged connective tissue attachment $[32,35]$. The penetration of bacteria from the side of the chamber into the interior of the tooth may occur as a result of a deep carious lesion, marginal microleakage; i.e., a fissure appearing on the border of the filling and hard tooth tissues from the developing secondary caries, and as a result of non-carious defects, such as attrition, abrasion, or erosion. The micro-organisms present in the carious dentin defect are usually strict anaerobes such as Actinomyces, Bifidobacterium, Lactobacillus, Eubacterium, Propionibacterium, and Rothia, and less-frequent Gram-negative species and streptococci [36]. After reaching the pulp, the micro-organisms that penetrate the dentinal tubules cause an inflammatory process, leading to necrosis if left untreated. Due to the specific conditions in root canals with dead pulp, caused by low oxygen levels and a low redox potential, anaerobic bacteria, especially Bacteroides, Fusobacterium, Peptostreptococcus, and facultative anaerobes, mainly Streptococci, are colonized there [37]. Potential outbreaks of infection in the oral cavity include deep carious cavities; teeth treated with the amputation method with the mummified pulp left in the canals; teeth improperly treated with a root canal, including incomplete or overcrowded; chronic inflammatory processes in the periapical area or furcations of a granulation type; root cysts; germ cell cysts; periapical abscesses; periodontal abscesses; pathological periodontal pockets; and ulcerative lesions on the oral mucosa [38-40]. Pulp diseases can also be caused by acute or iatrogenic mechanical factors and thermal factors, most often caused by iatrogenic treatment, when the pulp temperature exceeds $42^{\circ} \mathrm{C}$, causing irreversible changes [41,42].

Outbreaks of infections in the oral cavity can cause numerous complications, and not only locally [38], because approximately $80 \%$ of systemic diseases could be originating from the teeth, periodontal tissues, and tonsils [34,38]. The primary focus of infection is local chronic pathological changes, which are harmful effects that cause or maintain pathological changes in distant organs [43]. Pathological changes occurring in another organ resulting from the action of the primary lesion, as clinical systemic symptoms and local symptoms of the secondary focus, are considered focal disease [43]. Officially, this 
definition of an outbreak of infection was only given in 1980 [44]. However, the first mention of focal disease dates back to the time of Hippocrates, when dental extractions treated arthritis. Regardless of the local dental disease, caries is the primary focus of infection in numerous systemic focal diseases [40,44-64], and edentulousness resulting from caries affects further health complications [43,65-69]. Therefore, eliminating bacteria from the vicinity of potential infection foci in the oral cavity through early diagnosis and effective treatment is extremely important for the health of the whole organism and the maintenance of the well-being, quality, and length of human life. Hygiene and prevention of oral diseases are key, and if the disease has already occurred, its effective treatment at the earliest possible stage is essential for maintaining the general good health of the society. However, the issue is underestimated in many countries, not only by individuals, but also by governments [70], and it affects many social and economic aspects. Paper [1] presents a balanced model of modern dentistry and a matrix of advancement and treatment of oral diseases with the place of endodontics (Figure 2).
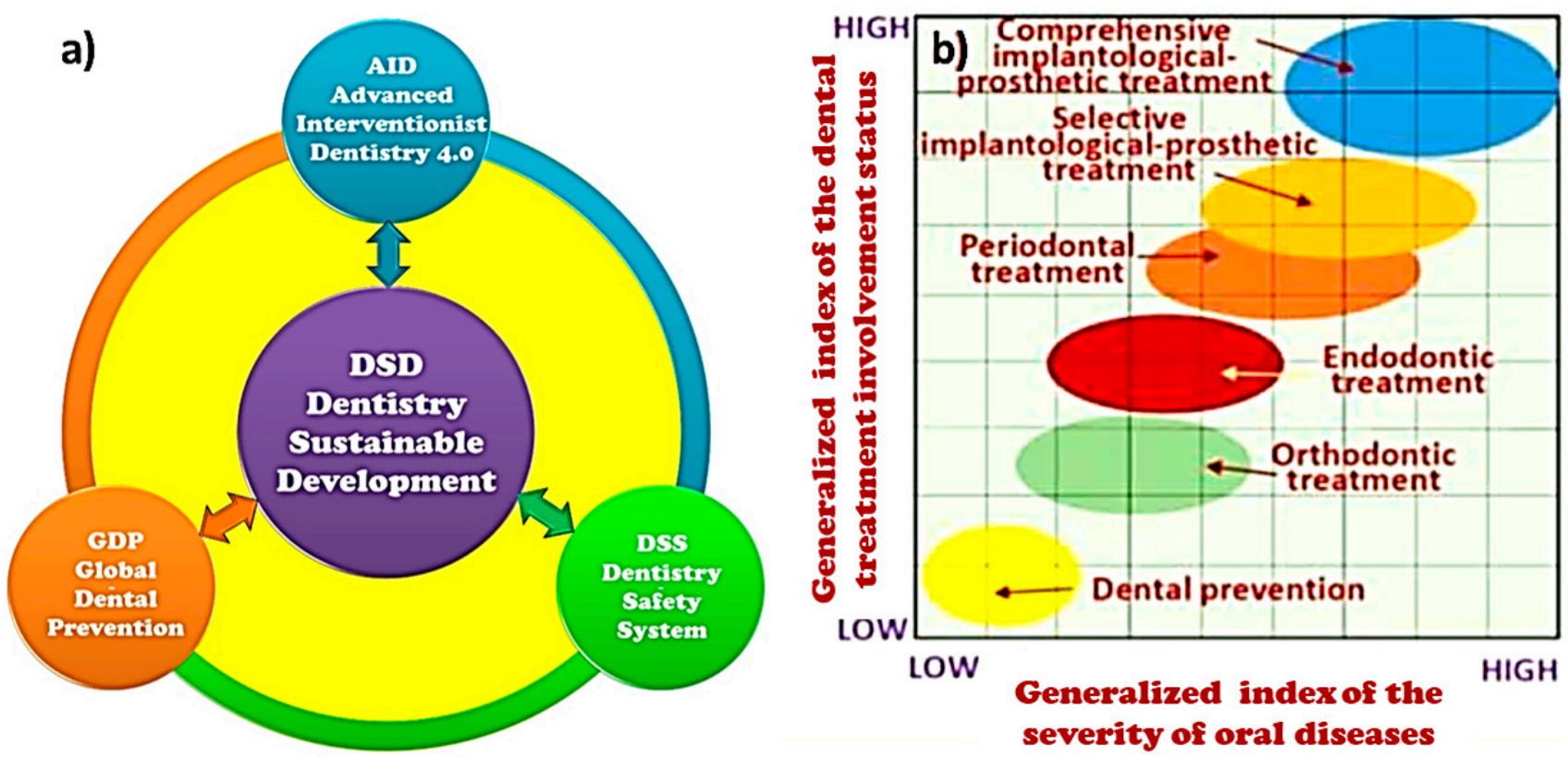

Figure 2. Diagram of the Dentistry Sustainable Development model (a), and an original concept of the matrix of advancement and treatment of oral diseases with the place of endodontics (b).

From the beginning of the 17th century, other methods were used to remove pulp diseases, including anaesthesia with clove oil, cauterization with a heated element, and devitalization with arsenic trioxide. In 1836, E. Maynard was the first to use a tool to remove the pulp from the inside of a tooth [71]. Currently, instead of tooth extraction, endodontic treatment can be successfully applied. After working out the interior and replacing the living tissue with a substitute biocompatible filling material, the tooth is retained as a pillar in the stomatognathic system. It successfully acts as a natural dental implant, also providing cosmetic qualities. Dentists prefer endodontic treatment to extraction for health reasons and to respect the aesthetic expectations of patients [72,73]. The decision on such treatment is made based on determining the severity of caries $[74,75]$ under the so-called "caries continuum" [76] and the classification contained in the International Caries Detection and Assessment System (ICDAS) [14,77-79]. To determine the type of treatment undertaken, the Precisions Caries Management System and the International Caries Classification and Management System (ICCMS) [70,80-83] are useful. Visual changes in enamel, dentin, and pulp allow for the identification of three levels of caries severity. It is necessary to analyze the risk [30,84-86] based on the caries development pyramid model (CDP) and the 5D Caries Management Cycle Rules (CMCR) [70]. 
The paper [1] presents the principle of the 5D caries management cycle rules (CMCR) as one of several "principles of the Fives". It is an original approach that does not repeat the content of literature studies, as a modification of the assumptions of the behavioural strategy based on the idea of the Deming Plan-Do-Check-Act (PDCA) cycle illustrating the basic principle of continuous improvement [87]. For evidence-based clinical caries treatment, especially in the early stages, this cycle covers the International Caries Classification and Management System (ICCMS). It shows how this system can be implemented as the 5D caries management cycle rules (CMCR) (Figure 3). The Five Main Activities of Dentistry (5MAD) was presented analogously as the principle of the Fives, with endodontics taking a prominent place. In turn, the Five Laws of Cleaning and Shaping the Pulp Complex (5LCSPC) was presented as the principle of the Fives (Figure 3c).
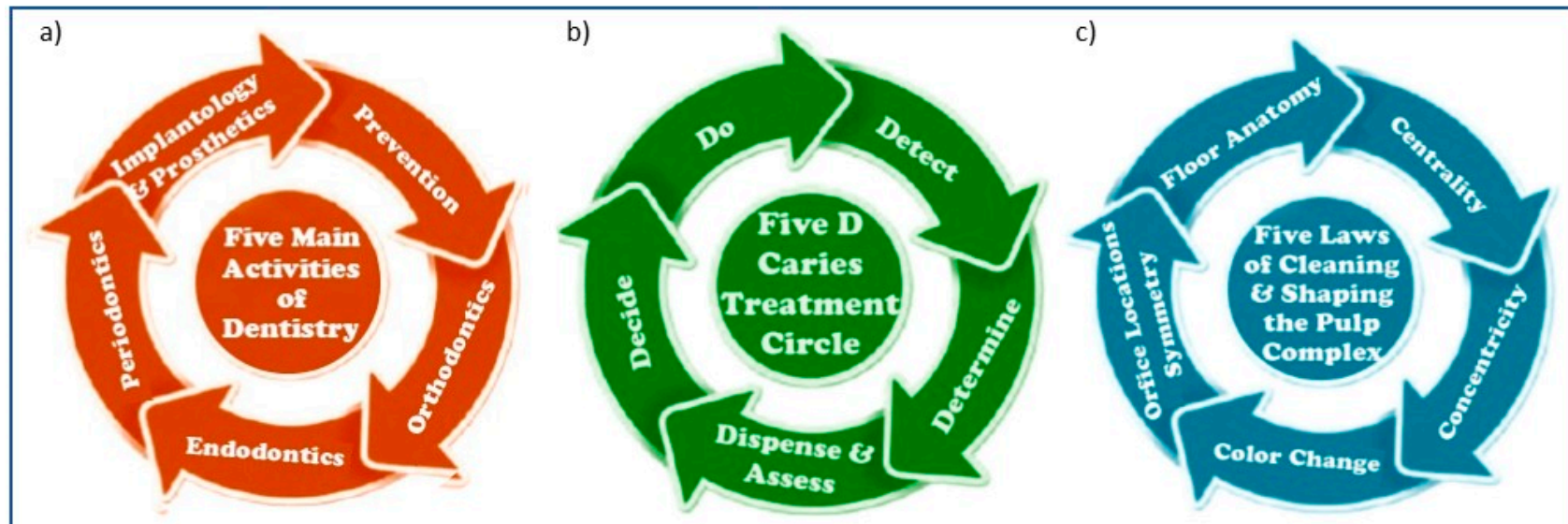

Figure 3. Diagram of the principles of the Fives: (a) Five Main Activities of Dentistry (5MAD); (b) Five D Caries Treatment Circle; (c) Five Laws of Cleaning and Shaping the Pulp Complex (5LCSPC).

\section{Main Goals of the Paper and Justification of Its Structure}

In this paper, two groups of achieved goals were designated. The first group of these goals includes an extensive review of the literature, which then made it possible to present the results of own experimental research using the original methodology of materialographic research and knowledge-engineering methods as the second group of the paper's goals.

It should be noted that some of the issues covered in this article may seem closer to the knowledge with which dentists are familiarized, while others are closer to dental engineers and their professional interests. In general, the main goal of this article is to equalize the level of knowledge of these two closely cooperating professional groups, based on thorough literature studies and specially planned and implemented experimental research. The result of this approach is an atypical hybrid structure of this article, with the first part being a review, and the second part being similar to what is known as an article.

Based on a review of the literature, theoretical factors determining the correctness of endodontic treatment were analyzed. Appropriate selection of filling material, contrary to the title of this article, cannot be a decision made by a dentist independent of other factors, mainly on the basis of their clinical experience. This decision requires taking into account many other factors, the analysis of which constitutes the essence of extensive literature studies preceding the experimental activities described in the second part of this article. The analysis of these factors began with an analysis of the method of qualifying teeth for endodontic treatment, including the presentation of appropriate principles in this regard. The method of root canal preparation in endodontic treatment is essential for the effectiveness of this treatment. Therefore, this issue was analyzed, with particular attention in the literature studies to the selection of tools for the preparation of the root canal. The importance of nitinol alloy tools, the selection of their chemical composition, 
and the importance of heat treatment of these tools and the accompanying phase changes were emphasized. For obvious reasons, this issue is not of direct interest to dentists, and the success of endodontic treatment largely depends on this factor. On the other hand, it is the dentist who decides which tool to use and how to use it. For this reason, this issue has been discussed in a separate section. The properties of root canal preparation tools undergo significant changes as a result of sterilization. It should be noted that each dental instrument, even those that are single-use, must be sterilized. Since this is a technological procedure that requires annealing at elevated temperatures, the importance of this procedure for changing the mechanical and functional properties of the tools requires analysis. This is another excerpt from the literature review. The method of obturating the root canals is very important. Based on a review of the literature, various obturation methods were analyzed started from the conventional cold consolidation to the relatively newest thermo-hydraulic condensation (THC) technique. Such an extensive and multifaceted review of the literature is the basis for presenting the results of our own research.

Previous reports on the effectiveness of endodontic treatment evaluation are highly controversial. In the authors' own work [70], it was presented that the quantitative methods of this evaluation commonly used by dentists in endodontics showed the lowest possible results. This applies, inter alia, to fluid-transport models, brightening techniques, dyepenetration tests, bacteria/metabolites penetration tests, glucose penetration tests, and methods using a dental optical microscope, which appear to be of marginal importance and with little development prospects, therefore they were not used in the experimental studies described in this paper.

Practical considerations regarding the effectiveness of endodontic treatment evaluation are discussed in the following sections. To assess the effectiveness of endodontic treatment, the methods usually used in materials science have been widely used.

An important element of the research hypothesis of this work is that in order to optimize the technology of developing and filling root canals, and testing the effectiveness of fillings, the measurement of which is the density and size of the gaps between the canal wall and the filling, microscopic methods of materialographic examination of microobjects and nano-structures were used. The problem of the research methodology is a specific problem selected for the combined objectives of this paper, indicated as one of the basic research questions to answer which research methods are most useful in assessing the effectiveness of endodontic treatment, assuming that the quality of root canal treatment is measured by leakage and/or a minimum number of the smallest possible gaps on the border of the root canal wall and the filling material. The demonstration that the use of previously rarely used materialographic research methods is a valuable methodological contribution of this work. The reasons for the uncommon use of modern high-resolution scientific and research equipment for this purpose can be defined, inter alia, as the difficult access to it for dentists, even if they engage professionally in scientific research; the need to significantly engage in mastering often methodically complex research techniques, requiring a lot of time and many years of experience to master these research methods and gain interpretive experience on a very large collection of tested preparations; and above all, daily access to a set of many expensive devices and/or interdisciplinary activity of specialists from various fields of knowledge. The studies conducted so far undoubtedly indicate the need to develop microscopic methods to evaluate the results of dental treatment, especially endodontic treatment.

In the authors' own work [70], the methods of matrix and scenario analysis, as well as the strengths-weaknesses-opportunities-threat (SWOT) analysis, were also used. The described methodology was used in the experimental studies described in the second part of the work in order to demonstrate the assumed thesis about the usefulness of the filling material based on gutta-percha and the practical use of these methods. 


\section{Principles of Tooth Qualification for Endodontic Treatment}

The effectiveness of endodontic treatment of teeth can be increased by removing the pulp complex. The pulp complex is a continuum, ranging from occlusal at the pulp horns to the apical foramen [88]. Complete and precise removal of the pulp complex requires identifying all root canal orifices in the pulp chamber. A rational and, at the same time, unrivalled method of achieving this goal is to apply the laws of the pulp chamber floor anatomy. It requires the dentist to ensure full access and visualization of the contact with the walls around the entire perimeter of the pulp chamber floor.

The complete removal of tissues from the pulp complex requires prior access to the coronal part of this complex. It is necessary to ensure the location and clean and shape the root canal or canals, ensuring the required strength of the coronal enamel and dentin. Actions taken by the dentist to this end include [89]:

- Preliminary analysis and diagnostic evaluation of teeth to qualify for endodontic treatment;

- Removal of the pulp chamber roof;

- Identification of the pulp chamber mouth and the bottom of the root canal opening; and

- Root canal instrumentation.

To qualify it for endodontic treatment, it is necessary to analyze the anatomy of the treated tooth and the surrounding tissues by identifying the coronal part of the system, the pulp chamber, and the root pulp. The law of centrality determines the position of the pulp chamber in the centre of the tooth at the level of the cementoenamel junction (CEJ) [90] (Figure 4), which, however, is not related to the occlusal anatomy [90], and usually does not correspond to the geometrical features of the prosthetic restoration of the tooth crown.

The physical identification of the shape and position of the CEJ can be made using a periodontal probe (Figure 4), and the radiographic examination, periodontal probing, and reconstruction of the probable position of the CEJ circumference are used to determine the correct position of the penetration point on the chewing surface. Cone beam computed tomography $(\mathrm{CBCT})$ is a key tool for making the proper diagnosis related to the diagnosis and planning of endodontic treatment. $\mathrm{CBCT}$, in combination with the routine use of a surgical microscope, allows a dentist to achieve the required precision in planning and performing endodontic procedures. The attending physician should trace the path of the entire root canal up to the apex, correctly assessing the prognosis of the procedure and selecting the necessary tools for the treatment. It is also beneficial to use the $35 \mathrm{~mm}$ X-ray machines located in the dentist's unit on an ongoing basis during the treatment so that each treatment stage is perfectly performed, thus increasing the long-term life of the treated tooth.

Alternatively, the location of CEJ can be made using the law of concentricity [90] (Figure 4), which states that the outer contour of the tooth at the CEJ level is concentric with the walls of the pulp chamber. A tooth bulge or constriction directly and accordingly affects the expansion or constriction of the pulp chamber (Figure 4). The tooth's angulation and a faciolingual direction can be determined by radiographic and CBCT studies, respectively (Figure 4). The radiograph also measures the distance between the furcation and the cusp tip and the cusp tip-pulp floor distance (CPFD). Directing the drill centrally concerning the CEJ and parallel to the long axis of the tooth with a length of bur in the handpiece correspondingly smaller than that of CPFD makes it possible to avoid chamber perforation in the furcation [91]. The shape of the hole contour, which may even fall out at the edge of the tooth, may be triangular, trapezoidal, or even irregular (Figure 4), and depends solely on the anatomical features of the pulp chamber [89]. 


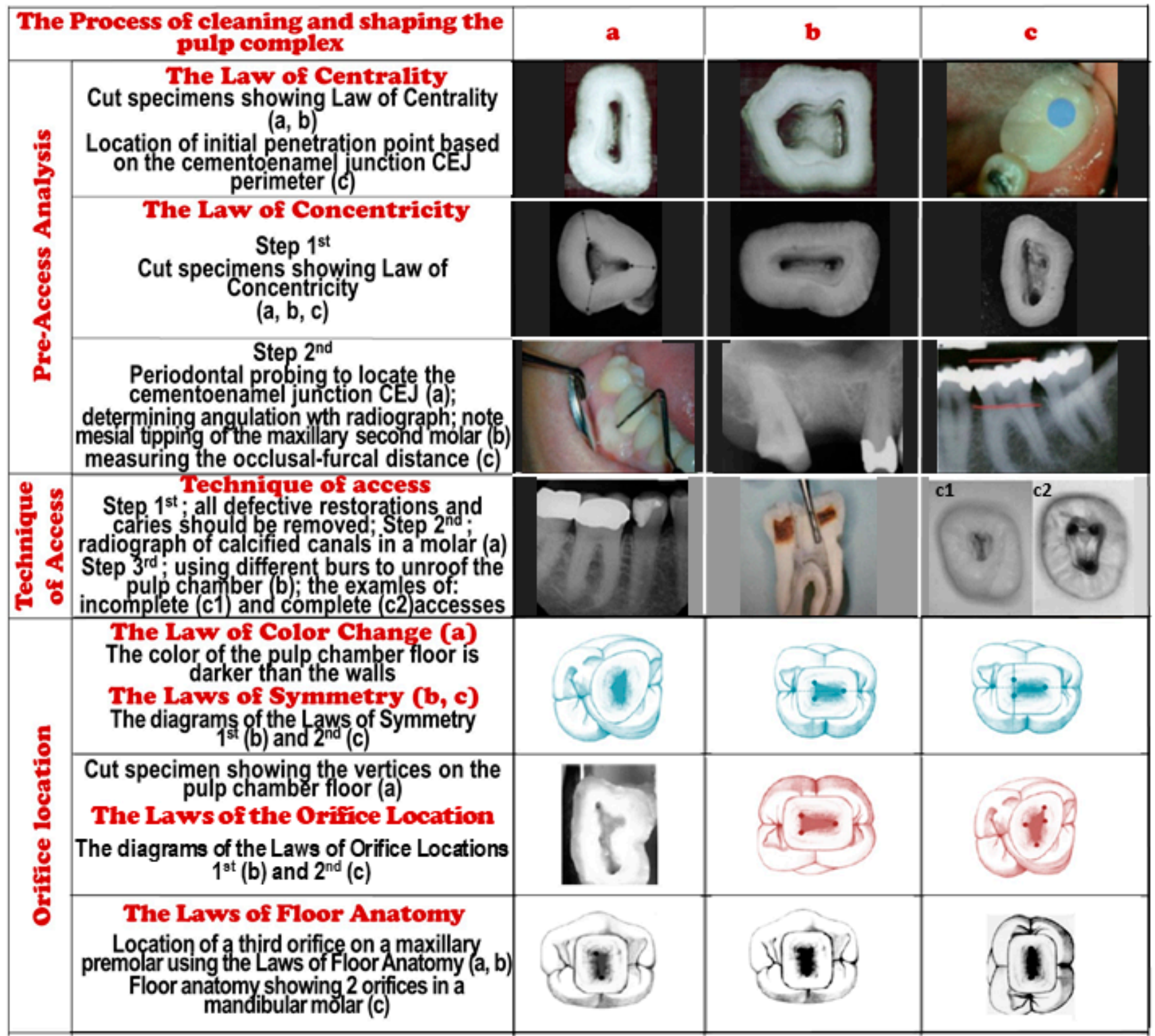

Figure 4. Diagram of the principles of tooth qualification for endodontic treatment based on the analysis of the anatomy of the treated tooth and the surrounding tissues; $(\mathbf{a}-\mathbf{c})$ show examples.

To prevent bacterial contamination during and after treatment, it is necessary to remove caries and previously made defective restorations before starting the drilling. The dentist selects the appropriate tools, including special fissure drills for cutting metal in prosthetic crowns, and drills the occlusal surface at the point chosen according to the previously described rules. Complete removal of the pulp chamber roof [92] makes it possible to search for holes. It should not groove or perforate the walls or floor of the chamber. Different burs are used to process the opening (Figure 4), and the openings will be exposed after the pulp chamber roof is exposed and completely removed. The law of colour change [90] indicates that the walls are lighter at the intersection with the pulp chamber floor, which is darker. This is, of course, a signal that access is complete. The entrance is full when the shade difference connection occurs over the entire range around the chamber's floor at the junction with its walls. In any case, when this difference is not visible, additional processing should be performed.

The number of canal openings in a given tooth is difficult to determine before treatment is started, and is necessary to prevent iatrogenic damage. An effective approach is to 
visualize the full extent of the pulpal floor using anatomical landmarks. Based on the laws of orifice locations, it is possible to determine the position of the canal orifices by drawing a mesial-distal line through the centre of the pulp chamber floor. They are situated equidistant on this line according to law 1 , or lie on a line perpendicular to this line according to law 2 (Figure 4). The maxillary molars are not affected.

All openings may only be along the wall-to-floor junction, indicating that any other locations in the chamber are redundant. The law of floor anatomy shows the number of channel openings. Sometimes, however, one hole may contain not one, but more root canals.

Endodontic treatment is used more commonly nowadays. Important circumstances include increased health awareness [93] and the will to correct negligence in preventing oral diseases [94]. In various countries, promotional activities are undertaken [93] to optimize expenditures on treating complications of oral diseases, resulting from the intensification of gerontological problems and a significant extension of human life [95]. The growing endodontics market in 2026 will reach the value of USD 2.1 trillion with a CAGR of $4.1 \%$ [70,94], and the dental consumables market partially related to it in 2023 will reach USD 55.584 million with a CAGR of $5.2 \%[70,93]$.

According to the clinical classification, pulp diseases can be divided into reversible pulpopathies, and irreversible pulpopathies treated endodontically and pulp necrosis [96,97]. Irreversible inflammation is most often associated with severe spontaneous pain, which draws the patient's attention to the need to seek help. On the other hand, pulp necrosis does not have to cause pain, thus causing the possibility of a latent, potentially infection focus in the oral cavity for many years. The spread of bacteria and possible toxins towards the root apex [98-100], also derived from saliva [101], is prevented by developing a previously infected root canal and its apical, lateral, and coronal sealing. The development of the root canal consists of the optimal use of the filling material, ensuring the best sealing of the root canal with an appropriately given and required shape after removing the contents inside it and after its careful disinfection. Root canal preparation techniques used to connect the dentin of this canal with the filling material are varied. Classic methods include the use of hand or rotary tools for cutting dentin for mechanical preparation and disinfection. In the laser method, dentin melts, recrystallizes, and closes the dentinal tubules.

In contrast, the ultrasound method uses sound vortices and the phenomenon of cavitation to prepare and disinfect the root canal [102-106]. As a result of a correctly performed endodontic procedure, the treated tooth remains in the oral cavity next to the healthy periapical and marginal periodontium. The tooth takes over the function of a natural pillar in the stomatognathic system. Statistically, endodontic treatment of teeth is performed more frequently in women. The endodontic treatment used least often is performed on incisors in the mandible, while premolars and molars in the maxilla [7] and molars in the mandible [107] are the most commonly treated.

\section{Importance of the Selection of Filling Material for Endodontic Treatment}

The basis for the success of endodontic treatment is the correct selection of the filling material. The root canal filling material fills the canal space during endodontic treatment, replacing the living tissue, which is an integral part between the enamel, dentin, and cement, and the rest of the body while maintaining the physiological functions of the tooth. In [108], the requirements for an ideal material for filling the root canal are specified.

In this paper, following the results of the virtual analysis contained in [70] and literature studies, experimental studies on the use of gutta-percha as a material for filling root canals of teeth are presented. These issues, as well as the detailed research methodology, are shown in the authors' cited own work [70], in which, among others, the possibility of removing the filling for endodontic retreatment was also highlighted [109]. In this paper, these issues are only discussed in general terms. For many years, gutta-percha has been the most commonly used natural material for filling root canals [110-116], and has even been recognized as the "gold standard of endodontics", and many studies have confirmed 
that it provides the best filling and tightness in the root canal [117-131], especially after a long time [132,133] and with the selection of non-standard sealing materials [117,134-137], although there are also contradictory reports in the literature [118,124,138-158] indicating the advantage of other filler materials and suggesting improper bonding of gutta-percha with dentin [159-168].

Gutta-percha was first used in endodontics in 1967 [70,169-171], although the thendeveloped method of filling the root canal was time-consuming and technically difficult. This method required that the heat exchanger be heated several times until it was red and then inserted several times into the channel next to the gutta-percha cone. After the heat exchanger was withdrawn, it was necessary to condense the plasticized gutta-percha left inside the canal with a pusher. The cycle had to be repeated several times with the use of several consecutive gutta-percha points. It was not until 1982 that the Touch'n Heat electric heat conveyor was implemented, then the real facilitation was the System B implemented in 1987, named after its inventor, Stephen Buchanan. It is still in use today, and provides constant pressure to fill with warm gutta-percha and root canal sealant and root canal seals while continuously providing heat and condensation through apical vertical movement using four sizes of Buchanan pluggers. Although System B allows temperature control up to $600{ }^{\circ} \mathrm{C}$, it should not exceed $350{ }^{\circ} \mathrm{C}$ to prevent the destruction of periapical tissues [169-171]. The real breakthrough is thermo-hydraulic condensation [172-177]. The purpose of this paper is the comparison of the practical usefulness of the System B and THC techniques.

Under the name gutta-percha, a mixture of $18-22 \%$ pure isomorphic $\beta$ gutta-percha, 59-75\% zinc oxide, $1.1-31.2 \%$ barium and strontium sulphate, as well as other polymers and wax in a proportion of 1:4, are used in endodontics, with 1\% [1] in the form of studs or pellets. The addition of zinc oxide improves plasticity and reduces brittleness, while barium sulphate provides X-ray impermeability so that it is possible to identify the filling using X-rays. Gutta-percha and the mixture mentioned above with its matrix gain the possibility of filling the root canal inside, thanks to its thermoplasticity. Other properties indicative of the usefulness of such a mixture in endodontics include inertness and biocompatibility, a melting point of $64^{\circ} \mathrm{C}$, and ductility and plasticity. Gutta-percha's density is $0.95-1.02 \mathrm{~g} / \mathrm{cm}^{3}$. Pure gutta-percha is a natural polyterpene, a polyisoprene polymer, sometimes called gutta, which has double bonds only in the trans configuration and contains 1,4 polyisoprene, which forms a rubbery elastomer. Gutta-percha is a mixture of gutta polymer with alcohol derivatives of triterpenes. It is a naturally biologically inert, rigid, resilient, thermoplastic, and electrically non-conductive latex made from the milk sap of Palaquium gutta trees, as well as Palaquium oblongifolia, Mimusops balata, and Eucommia ulmoides from the Malay Peninsula and Indonesia, the common euonymus in Europe Parvifaria and Excoifolia [70].

Using a material based on gutta-percha each time requires the combined use of sealants $[178,179]$ based on synthetic resins, in both the cold and thermoplastic condensation methods. The material, with a gutta-percha matrix and the sealant, ensures a tight bond with the root canal wall. The quality of endodontic treatment depends mainly on the tightness of filling the root canal with filling material and its tight connection with the dentin of the canal.

The advantage of the material based on gutta-percha over other filling materials was also confirmed by our own analyses [70]. Therefore, this paper aims to confirm the thesis about the full suitability of the material based on gutta-percha as a filling material in endodontics.

\section{Methods and Tools of Root Canal Preparation in Endodontic Treatment}

Apart from the correct selection of the filling material, another important factor determining the success of endodontic treatment is the method of root canal preparation. The development of a root canal consists of removing the contents inside the root canal, disinfecting it, and giving it a shape to ensure the best hermetization of the root canal with 
the filling material. In endodontics, to prepare the dentin of the root canal for connection with the filling material, one can use the classical mechanical preparation methods and achieve disinfection by cutting the dentin with hand or rotary instruments, a laser, or ultrasound [102-106]. Tool wear or damage depends on the dentist's experience [180] in using crown-down techniques to reduce the risk of dead pulp debris and cut dentin filings being forced past the apical opening [181,182]. In addition to the correct selection of the filling material, the obturation technique, and the method of root canal preparation, an important factor is selecting rinsing fluids and lubricants that are the most appropriate for the tools used. The dentist expects the proper manufacture of the tools they are sourcing, showing confidence in the tool producers. Various studies compared the test results of various endodontic tools [183]. In [70], a virtual analysis was performed, making it possible to narrow down the considerations in the practical verification of selected cases. For endodontic procedures, dentists very often use corrosion-resistant steel hand and rotary tools. The risk of breaking tools made of corrosion-resistant steels is significant due to the lack of flexibility of the tools and the resulting lack of adjustment of the tools to the natural curvature of the root canal in many clinical situations [181].

In 1988, a nickel-titanium alloy [184-186], known as nitinol, was introduced to produce endodontic tools. Nitinol's name is an acronym for Nickel Titanium-Naval Ordnance Laboratory, where this alloy was discovered in 1959 [187-190]. The authors' work [70] presents a literature review concerning the selection of the chemical composition and processing conditions of these alloys and their importance in the endodontic treatment of teeth. Considering the results of our own virtually conducted analysis [70] and the conducted literature review, this paper analyzes variants of root canal preparation with the use of hand and rotary tools made of nitinol in endodontics. This alloy has a shape memory [191]. Due to this effect, nitinol tools do not undergo permanent deformation. They are characterized by high fatigue strength [180,184-186,192-196] and mechanical resistance to fractures [185]. They can be used for manual or rotational preparation [181,197]. The conicity, radial contact surface, blade angle, and shear angle of endodontic instruments vary [181,198-200]. Nitinol endodontic instruments have the advantages of effectively removing dentin filings and pulp debris from the root canal, ensuring its natural course, maintaining a stable working length, and minimizing the removal of dentin from its wall [201]. The number of nitinol tools is relatively smaller than those made of corrosion-resistant steel $[200,202,203]$. At the same time, the risk of breaking the tool during root canal preparation is lower [204], as is the number of cases of pulp and cut canal dentin being pushed past the apical opening [205].

It is most preferred to make endodontic tools from a nitinol alloy in which the atomic concentration of the elements corresponds to the stoichiometry of the Ni-Ti intermetallic phase. Since the physical properties of endodontic tools are lowered by the remaining elements, care should be taken to ensure that their concentration in the alloy is as low as possible. In [206,207], the importance of the composition of nitinol alloys was analyzed. The $\mathrm{Ni}$-Ti phase equilibrium diagram (Figure 5a) was developed in [208], and some changes were introduced later [209-213]. Relatively small changes in the mass concentration of nickel within the narrow range of approximately $48-51 \%$ permitted by the standards [214] significantly affect the functional properties of medical devices, including endodontic tools made of this material [215]. Its influence on the value of the $\mathrm{M}_{\mathrm{s}}$ temperature is significant [216,217], which for the stoichiometric chemical composition of $\mathrm{Ni}_{50} \mathrm{Ti}_{50}$ is about $65^{\circ} \mathrm{C}$, and is radically reduced even to about $-140^{\circ} \mathrm{C}$ in the case of a slight advantage of the nickel concentration over the equilibrium [218], determining significant changes in the physical properties of the alloy [215]. 


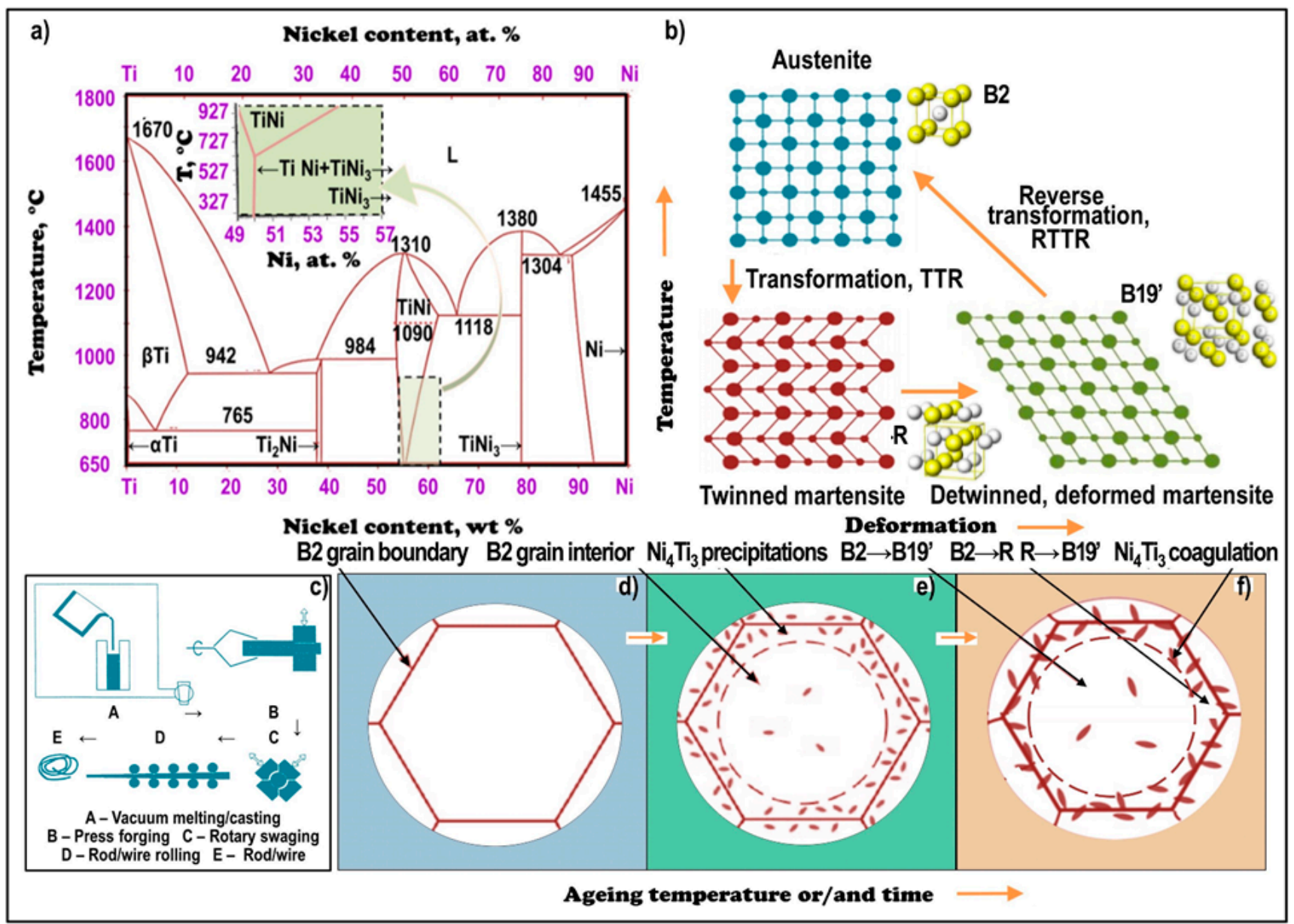

Figure 5. Diagram of information on nitinol alloys: (a) Ti-Ni phase equilibrium system; (b) diagram of phase transformations determining the shape memory and superelasticity effects; (c) diagram of the technological process of nitinol-type substances; (d) structure of austenite B2; (e) separation of $\mathrm{Ni}_{4} \mathrm{Ti}_{3}$ in the border zone of austenite B2; (f) coagulation processes of precipitates in the austenite border zone favouring the transformation of B2 $\rightarrow \mathrm{R}$ and then $\mathrm{R} \rightarrow \mathrm{B} 19^{\prime}$ with the B2 grain interior not changing the chemical composition, in which a one-stage martensitic transformation takes place (B2 $\rightarrow$ B19').

The method of manufacturing nitinol alloy also has a significant impact on its properties $[184,187,218,219]$ due to the possibility of reducing the proportion of non-metallic $\mathrm{Ti}_{4} \mathrm{Ni}_{2} \mathrm{O}_{\mathrm{x}}$ inclusions $[220,221]$ and elimination of uncontrolled changes in the ratios between the atomic concentrations of nickel and titanium, resulting in stabilization and improvement of fatigue properties, requiring the use of raw materials of the highest purity [222-224]. The electro-arc melting technology of nitinol alloys seems to be useless, while their manufacturing by the vacuum arc remelting (VAR) [221,225] of high purity [225], with a smaller (usually 5-10 times smaller) proportion of non-metallic inclusions than in the case of standard melt and fatigue strength several times higher [225]. The most advantageous is the manufacturing of nitinol by the vacuum induction melting (VIM) method, which ensures the lowest possible share of non-metallic inclusions [225] and increased fatigue strength $[222,223]$.

Nitinol endodontic tools are manufactured from drawn or extruded rods or wires. Nitinol alloy is subjected to hot forming only, mainly by drawing and extrusion, and rolling and forging (Figure $5 \mathrm{c}$ ). It is one of the materials that are difficult to subject to plastic deformation. Therefore, endodontic tools made of nitinol are manufactured by removal methods using milling with carbide tools and subsequent grinding [226,227]. However, it is impossible to manufacture technologies used for endodontic tools made of corrosion-resistant steel by twisting [228], due to the risk of scrapping the tool during the manufacturing pro- 
cess [228]. The required properties, including mechanical fracture resistance [185], should be ensured by heat treatment combined with cold working $[48,229]$. The technologies used also include laser cutting, grinding, and electrical discharge machining [218]. Increasing the fatigue strength $[180,184-186,192-195]$ is also ensured by electropolishing (EP) and magneto-electropolishing (MEP) in a constant magnetic field [49-51,192-195,230,231]. Additive technologies [232], drawing [233] or cold rolling [234], high-pressure torsion (HPT) [235], and equal channel angular pressing (ECAP) [236] can also be used for the manufacturing of tools using nitinol alloy. The favourable fineness of the austenitic matrix grain $[237,238]$ depends on the heat treatment conditions $[239,240]$ and the given technological processes, deciding the course of the $\mathrm{Ni}_{4} \mathrm{Ti}_{3}$ [241,242] dispersion precipitation processes in austenite and martensitic transformation, respectively, in the B19' or R structure phases [242,243].

The unique features of nitinol endodontic tools, known as shape memory and superelasticity (Figure $5 b$ ), are essential, and are determined by the unidirectional shape memory effect and the superelasticity and bidirectional shape memory effect $[218,244-248]$. Thermoelasticity reversible martensitic transformation, in almost stoichiometric Ni-Ti alloys, even with a slight predominance of nickel [249], is responsible for these phenomena. The unidirectional shape memory effect causes the workpiece to return to its original shape due to the martensitic transformation sequence induced by deformation or hardening, and the subsequent reverse transformation of martensite into an austenitic parent phase when heated to the characteristic temperature [248]. The phenomenon of superelasticity consists of solely remembering the shape of the high-temperature mother phase, and results from the course of the reversible martensitic transformation under the influence of external stress [218]. The two-way memory effect of the shape of the alloy applies to both the high-temperature mother phase and the low-temperature martensitic phase $[69,187,188,190,191,250-253]$. In this case, in the $\mathrm{M}_{\mathrm{f}}-\mathrm{A}_{\mathrm{f}}$ temperature range, respectively representing the end of martensitic transformation and the end of austenite formation, cyclical changes occur, causing reversible changes in the object's shape, without external stress and without removing the martensite nuclei [248].

The cooling rate during homogenizing annealing [254,255] plays an important role, especially cooling in the critical transformation temperature range (TTR), defined as the range between the temperature of the beginning $\left(\mathrm{M}_{\mathrm{s}}\right)$ and the end $\left(\mathrm{M}_{\mathrm{f}}\right)$ of the martensitic transformation. The cooling rate influences changes in the modulus of elasticity, yield point, electrical resistance, and the shape memory effect [187,188,190,191,250-253]. It results from the martensitic transformation B2 $\rightarrow$ B19', with the simple cubic structure B2 of austenite (also known as the parent phase) $[187,188,190,191,250-253,256]$ occurring above approximately $100{ }^{\circ} \mathrm{C}$ in twinned martensite with the monoclinic crystal structure B19' (daughter phase) (Figure 5b) $[69,187,188,190,191,250-253]$. In the reverse transformation temperature range (RTTR), during successive heating, the transformation of martensite into the mother phase; i.e., high-temperature austenite with a stable energy state, takes place, defined as the inverse martensitic transformation according to the B19' $\rightarrow$ B2 scheme $[187,188,190,191,250-253]$, deciding the shape memory effect (Figure 5b). The martensitic transformation and the reverse martensitic transformation are immediate $[187,188,190,191,250-253]$. The hysteresis range of the martensitic transformation usually covers $20-50^{\circ} \mathrm{C}$, but it can be reduced or increased by appropriate alloying additives [67] or technological processes [68,187,188,190,191,250-253].

In almost stoichiometric Ni-Ti alloys in austenite, with relatively large grains sized 6.6 to $21.7 \mu \mathrm{m}$ [249] formed after heating $>800{ }^{\circ} \mathrm{C}$, a single-stage martensitic transformation takes place according to the scheme B2 $\rightarrow$ B19' [218]. This may also take place in alloys with a relatively slight advantage of $\mathrm{Ni}$ [249]. As the austenite grain grows, there is an uneven release of the metastable $\mathrm{Ni}_{4} \mathrm{Ti}_{3}$ phase $[242,257,258]$ (Figure $5 \mathrm{~d}-\mathrm{f}$ ), which is accompanied by a local reduction in nickel concentration in the matrix zones surrounding the precipitates. 
$\mathrm{The} \mathrm{Ni}_{4} \mathrm{Ti}_{3}$ precipitates have the following strictly defined crystallographic orientation concerning the parent matrix of the B2 structure [259]:

$$
(1 \overline{1} 0)_{\mathrm{Ti}_{3} \mathrm{Ni}_{4}} / /(\overline{3} 21)_{\mathrm{B} 2} ;[111]_{\mathrm{Ti}_{3} \mathrm{Ni}_{4}} / /[111]_{\mathrm{B} 2}
$$

or, alternatively:

$$
(1 \overline{1} 0)_{\mathrm{Ti}_{3} \mathrm{Ni}_{4}} / /(\overline{3} 12)_{\mathrm{B}_{2}} ;[111]_{\mathrm{Ti}_{3} \mathrm{Ni}_{4}} / /[111]_{\mathrm{B}^{2}} \text {. }
$$

The separation of the $\mathrm{Ni}_{4} \mathrm{Ti}_{3}$ phase in the coarse-grained austenite of the $\mathrm{B} 2$ structure resulting from annealing takes place near the grain boundaries, causing the matrix to become lower in nickel concentration in these areas. The ageing conditions, both the temperature and the treatment time [260], significantly impact the morphological features of these precipitates. As they increase, their coagulation occurs, and the matrix is further lowered in nickel concentration. As a result of the precipitation of the $\mathrm{Ti}_{3} \mathrm{Ni}_{4}$ phase, changes in the temperature of the start $\left(\mathrm{M}_{\mathrm{S}}\right)$ and finish $\left(\mathrm{M}_{\mathrm{f}}\right)$ of the martensitic transformation occur $[249,261]$. The methods counteracting the growth of austenite grains and intensification of precipitation processes include electric pulse treatment (EPT) technology [262] in combination with stretch-bending deformation (SBD) [262] and annealing, as a result of which, the martensitic transformation plateau is improved.

Due to the coherent or semicoherent boundaries of the $\mathrm{Ti}_{3} \mathrm{Ni}_{4}$ phase precipitations with the matrix of B2 structure [263-266], matrix precipitation hardening takes place according to the Orowan mechanism [240]. It is important for the course of the martensitic transformation into the phase with the structure B19' [267-269], and the stresses around these precipitates strongly counteract the direct transformation of B2 $\rightarrow$ B19'. In turn, the lack of these stresses or their significant reduction favours the formation of the martensitic phase $\mathrm{R}$ according to the scheme $\mathrm{B} 2 \rightarrow \mathrm{R}[240,270]$. In turn, the growth of $\mathrm{Ti}_{3} \mathrm{Ni}_{4}$ precipitates with the increasing of time influences the generation of dislocations with the

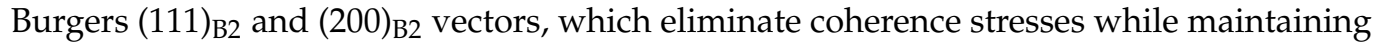
coherence in other areas [271]. Such conditions favour the transformation of B2 $\rightarrow R$ during cooling $[249,267-269,272]$. A significant stress field is generated by the precipitation processes of $\mathrm{Ti}_{3} \mathrm{Ni}_{4}$. Thus, it enables a two-variant course of a direct or two-stage transformation $[264,265]$ associated with increasing the transformation temperature B2 $\rightarrow$ $R$ [267]. According to the scheme B2 $\rightarrow R$ [256], the martensitic transformation into the $\mathrm{R}$ phase usually results from the premature ageing associated with the precipitation of $\mathrm{Ti}_{3} \mathrm{Ni}_{4}$ phase particles in the $\mathrm{B} 2$ matrix. The mechanism of this transformation is described in many papers $[218,250,256,273,274]$. As a martensitic transformation, it also proceeds through shear, and because it is also reversible, it is also responsible for shape memory and superelasticity effects $[275,276]$. It has been assumed that this phase has a rhombohedral lattice structure and was therefore named R, although it is known that it has a trigonal structure P3 [277] and should be denoted as the T phase [250]. By tradition, the $\mathrm{R}$ name is used. The transformation of $\mathrm{R} \rightarrow \mathrm{B} 19^{\prime}$ is not a martensitic transformation, as was mistakenly thought previously. Still, it is related to the reconstruction of the martensite lattice [218], and the view that in each stage of the transformation B2 $\rightarrow \mathrm{R} \rightarrow \mathrm{B} 19^{\prime}$, the martensitic transformation takes place sequentially is not true. It is different in separating coarse-grained precipitates of the $\mathrm{Ti}_{3} \mathrm{Ni}_{4}$ phase because their growth and coagulation and the resulting lack of coherence favour the direct transformation of B2 $\rightarrow B_{1} 9^{\prime}[211,278,279]$. Then the proportion of $\mathrm{Ni}_{4} \mathrm{Ti}_{3}$ decreases, or this phase decomposes into a mixture of $\mathrm{Ni}_{3} \mathrm{Ti}_{2}$ and $\mathrm{Ni}_{3} \mathrm{Ti}$ [279]. The precipitation hardening mechanism by $\mathrm{Ti}_{3} \mathrm{Ni}_{4}$ phases is then less effective [240] with the extension of the ageing time and an increase in the ageing temperature, thus reducing the hardness of nitinol [240]. The aged effect determines the characteristic parabolic course of hardness changes with the extension of the soaking time [240]. Under these conditions, nitinol exhibits only a one-sided shape memory effect [271]. 
A crystallographic relationship was found between the parent phase B2 and the other phases [265], as given below:

$$
[101]_{{\mathrm{B} 19^{\prime}}^{\prime}} / /[111]_{\mathrm{R}} / /[111]_{\mathrm{Ti}_{3} \mathrm{Ni}_{4}} / /[111]_{\mathrm{B} 2}
$$

The B2 $\rightarrow \mathrm{R}$ transformation implies significant application possibilities, and for its course, it is necessary to suppress the direct transformation into B19' martensite according to the $\mathrm{B} 2 \rightarrow \mathrm{B} 19^{\prime}$ scheme. Taking advantage of the B2 $\rightarrow \mathrm{R}$ transformation due to the properties and behaviour of nitinol alloys [218] requires precise control of its course [249], especially its temperature range [225,280-282], annealing temperature [283], and temperature [284] and ageing time [285]. The main positive effects of this transformation include not only increased fatigue strength [225,280-282], but also considerable stability under cyclic changes in temperature and loads $[225,281,286]$, quick response to temperature changes $[250,276,281,284,287]$, and a narrow hysteresis loop [250,288]. Activation of the B2 $\rightarrow \mathrm{R}$ transformation is favoured by annealing after plastic deformation $[289,290]$, ageing of alloys with a relatively small advantage of nickel atomic concentration $[239,240,249,261,273,291-293]$, as well as cyclic temperature $[283,285,294,295]$ and stresses changes [296,297]. Regardless of the R phase formation, the martensitic transformation of B2 $\rightarrow$ B19' is still possible. This requires even greater subcooling [249] and a correspondingly high cooling rate from the homogenizing annealing temperature; e.g., in water. Then, after the course of the $\mathrm{B} 2 \rightarrow \mathrm{R}$ transformation, a direct $\mathrm{B} 2 \rightarrow \mathrm{B} 19^{\prime}$ transformation takes place, and there is a two-stage B2 $\rightarrow \mathrm{R} \rightarrow \mathrm{B} 19^{\prime}$ transformation [249,270-272,289,298-301], which follows when the grains are fine, and their size is $\leq 5.6 \mu \mathrm{m}$. The grinding of grains after cold plastic deformation is related to the variation in their size, which may weaken the stress-induced martensitic transformation plateau [302]. The transformation of B2 $\rightarrow \mathrm{R} \rightarrow \mathrm{B} 19^{\prime}$ may occur regardless of the nickel concentration [249], but also with the predominance of the atomic concentration of titanium [303]. Still, it cannot occur in monocrystals; therefore, it occurs only in polycrystals [249].

As a result of the differentiation of nickel concentration at the boundaries and inside the grains of Ni-Ti alloys caused by the $\mathrm{Ni}_{4} \mathrm{Ti}_{3}$ and phase-precipitation processes in a privileged way at the B2 phase boundaries, in one element of the nitinol alloy, the direct transformation of B2 $\rightarrow{\mathrm{B} 19^{\prime}}^{\prime}$ and the two-stage B2 $\rightarrow \mathrm{R} \rightarrow{\mathrm{B} 19^{\prime}}^{\prime}$ transformation occur [249]. Subsequent precipitation, growth, and coagulation of $\mathrm{Ni}_{4} \mathrm{Ti}_{3}$ phase particles at the grain boundaries causes a local decrease in nickel concentration as the ageing time lengthens and/or as a result of an increase in the ageing temperature (Figure 5e,f) [249], which results in different nickel concentrations at the grain boundaries and inside $\mathrm{Ni}-\mathrm{Ti}$ alloys. In the zone adjacent to the grain boundaries, the two-stage transformation of $\mathrm{B} 2 \rightarrow \mathrm{R} \rightarrow$ B19' [249] is induced in this way when the direct transformation of B2 $\rightarrow$ B19' [249] takes place inside the grains with a relatively higher concentration of nickel [249]. At higher than the equilibrium concentration of nickel in the alloy, there are conditions for homogeneous precipitation of $\mathrm{Ti}_{3} \mathrm{Ni}_{4}$ phase particles during ageing in the entire grain volume. With a relatively longer ageing time, the growth and coagulation processes of precipitates also occur. As a result of the lack of differentiation of nickel concentration in different zones of B2 austenite grains, a one-stage direct transformation of B2 $\rightarrow$ B19' is normally carried out [249].

During reheating, the opposite transformation of $\mathrm{B} 19^{\prime} \rightarrow \mathrm{R}$ takes place in a relatively short time, while after lengthening the time, the direct formation of austenite via B19 ${ }^{\prime} \rightarrow \mathrm{B} 2$ and most probably $\mathrm{R} \rightarrow \mathrm{B} 2$ are dominant [304].

\section{Importance of Sterilization of Endodontic Instruments and Lubricants for the Effectiveness of Root Canal Preparation}

The essence of the dentist's work in performing endodontic procedures shows that all tools must be sterilized due to the necessity to meet sanitary and epidemiological requirements [305-308], which also applies to nitinol endodontic tools [305-327]. The issue is described in more detail in the authors' own work [239]. Various research methods have 
been selected regarding this issue, including the differentiation of the studied material, which is treated as a model corresponding to clinical conditions. The spectrum of possibilities that currently are most common includes polymeric blocks (methyl methacrylate PMMA) [311,314], with cylindrical canals symbolizing curved root canals [305,309,311,314], sometimes alternatively made of other polymeric materials [312] or phenolic resin [313], but also with the use of dentin of extracted human teeth [313,317,319], or bovine teeth [318] and bones [315,316,318]. The performed tests involved measuring the cutting efficiency [314] with or without irrigation $[312,313]$ further, with the use of "push and pull" linear motion $[315,317]$ or rotary motion concerning the long axis of the tool. Metallographic examinations using a scanning electron microscope (SEM) and/or an atomic force microscope [322,323] help assess the results of these tests [320,321,324,325].

The measure of the effect of sterilization on the properties of endodontic tools is the cutting efficiency as the ratio of the weight of the cut PMMA plate with an accuracy of $3 \times 10^{-5} \mathrm{~g}$ related to the unit of energy used during cutting in $\mathrm{Mg} / \mathrm{J}[311,314]$. Compared to conventional stainless-steel tools, which the sterilization processes do not significantly affect [312,313], in the case of nitinol tools, sterilization causes a significant decrease in cutting ability and efficiency $[305,309,310,313]$. For example, a significant decrease in the cutting efficiency of nitinol rotary tools was found under the influence of repeated 14 or 7 sterilization cycles compared to non-sterilized ones (Figure 6) [305]. The reason for such changes is that repeated sterilization causes a change in the surface structure of endodontic tools [305] due to a significant increase in the content of titanium oxide on the surface [305]. Treatment by chemical disinfection with sodium hypochlorite $\mathrm{NaOCl}$ did not significantly affect the cutting performance of endodontic instruments [311]. The treatment of nitinol tools by applying TiN to their surface using the physical vapour deposition PVD process did not increase the efficiency after multiple sterilizations in an autoclave in combination with an initial exposure to sodium hypochlorite $\mathrm{NaOCl}$ [309].
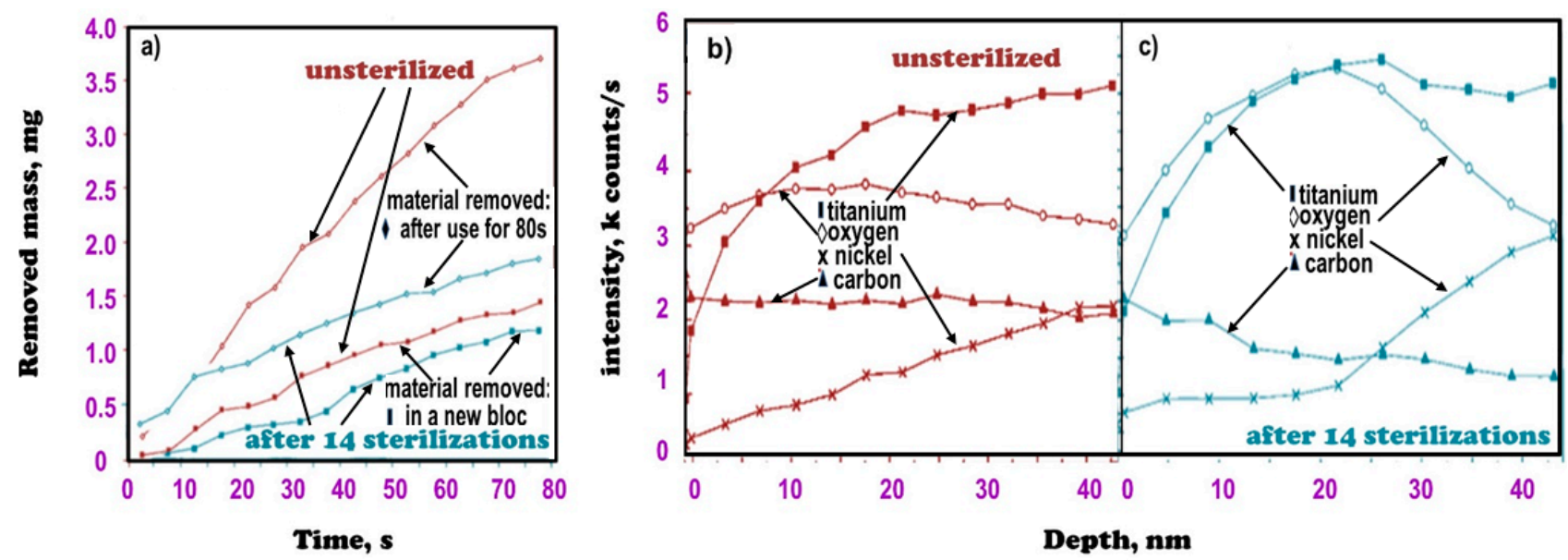

Figure 6. Properties of nitinol endodontic tools as delivered and after subsequent sterilization processes: (a) weight loss of the tool after drilling in a PMMA trial block with a simulated root canal used immediately after delivery or after repeated use for $80 \mathrm{~s} ;(\mathbf{b}, \mathbf{c})$ changes in the concentration of $\mathrm{Ti}, \mathrm{O}, \mathrm{Ni}$, and $\mathrm{C}$ on the tool surface in the delivered condition (b) and after subsequent sterilization cycles (c).

During the mechanical preparation of root canals, irrigating the canals with appropriate rinsing fluids after each inserted tool is necessary. Rinsing fluids remove organic and inorganic debris from root canals and eliminate micro-organisms. The properties of a root canal rinsing agent include a wide range of actions against micro-organisms inhabiting the canals, the ability to neutralize toxins, the ability to dissolve organic compounds, (i.e., living and dead dental pulp), and the ability to rinse out dentin filings. Several rinsing fluids can be used to achieve the goal of disinfecting the root canal and preparing it for filling with replacement material, each with advantages and disadvantages. During en- 
dodontic treatment, the most frequently used irrigation fluid is sodium hypochlorite at a concentration of 0.5 to $5.25 \%$ [182,328-330]. Sodium hypochlorite has strong bactericidal properties and dissolves organic residues. However, it does not completely remove the smear layer due to the lack of action on inorganic substances. The bactericidal properties of sodium hypochlorite increase with the increase in the concentration in which it can be used during root canal irrigation. Unfortunately, as the concentration increases, its toxicity to living tissues increases. If the fluid penetrates beyond the apical opening of the canal, it may result in complications in the form of pain during biting and even the appearance of spontaneous pain [182].

Therefore, most in vivo and in vitro studies recommend using sodium hypochlorite channels at a concentration of 2 to $3 \%$ for irrigation. This concentration can destroy mixed anaerobic flora and is less toxic to periapical tissues than higher concentrations. In addition, studies [331] have shown that solutions with a concentration of $5.25 \%$ reduce the dentin flexural resistance due to the ability to cause proteolytic degradation of collagen fibres, which does not occur at lower sodium hypochlorite concentrations. Irrigation reduces the root canal dentin [329], with less sodium hypochlorite and more with sodium edetate irrigation. Sodium edetate, or ethylenediaminetetraacetic acid disodium salt dihydrate, is the sodium salt of the ethylene diamino tetraacetic acid known as ethylenediaminetetraacetic acid (EDTA), which is an aminopolycarboxylic acid with the formula $\left[\mathrm{CH}_{2} \mathrm{~N}\left(\mathrm{CH}_{2} \mathrm{CO}_{2} \mathrm{H}\right)_{2}\right]_{2}$ [332]. This compound can dissolve the dentin of the root canal due to the ability to exchange magnesium and calcium ions with sodium ions, thanks to which water-soluble compounds are formed. This mechanism increases the susceptibility of the canal dentin to cutting during mechanical preparation with the use of endodontic tools.

In addition to the rinsing preparations used for the work of the tool in the canal, each inserted tool must be covered with lubricant. The lubricants are designed to slip the tool into the canal [333], preventing it from jamming, thus reducing the risk of the tool breaking into the canal. Lubricants are ready-made preparations, the basic ingredient of which is always glycerin. Additionally, they may contain urea peroxide or sodium edetate. Urea peroxide owes its bactericidal and lytic properties to oxygen evolution. It can penetrate the narrowest canals and have a bactericidal effect due to its low viscosity and low surface tension. Preparations containing urea peroxide must always be used in conjunction with irrigation with sodium hypochlorite solution. Combining these two compounds causes a chemical reaction in the form of the release of oxygen bubbles $[334,335]$.

\section{Review of Root Canal Obturation Methods}

Another important element in the success of endodontic treatment is obturation techniques. These techniques, like the materials for filling the root canals, have developed over the years. Only the goal of each endodontist has remained unchanged-tight filling of the root canal system, no complications in the form of pain, periapical changes, or root fractures. Modern techniques, which often require specialized equipment and materials, minimize the risk of complications during and after treatment. Due to the assumptions made in this article regarding gutta-percha as a filling material, further considerations are limited to this material only.

Over the years, techniques of obturation of root canals have been perfected. The generally accepted condition for optimal filling is tight, three-dimensional obturation of the canal to the physiological opening. A root canal filling that meets these conditions protects the periapical tissues against secondary infection, which may arise due to the material not sticking to the root canal walls. Then, micro-organisms residing in the dentinal tubules or side branches can penetrate the periapical tissues and cause reinfection. Additionally, the development of marginal leakage between the material filling the cavity and the tissues of the tooth crown increases the risk of reinfection [131,336,337].

The basic and still valid method is the side condensation of gutta-percha, which uses gutta-percha points and paste sealant. This method assumes matching the main cone 
corresponding to the master apical file MAF size and then filling the canal with smaller size studs, for which a place has been prepared in advance by a manual spreader [338]. It has been shown [339] that in the side condensation technique, there are fewer pushes of the material beyond the apex opening compared to the compared thermoplastic techniques. When the root canal is prepared with tools with a conicity of 0.4 , the use of the main cone with a conicity of $0.2 \%$ during lateral condensation increases the risk of the expander exceeding the root canal's working length during condensation [340].

In 1976, the first information appeared to introduce plasticized gutta-percha into the root canal [341]. It quickly turned out that plasticized gutta-percha resulted in a greater chance of three-dimensional obturation of the root canal. Therefore, in a short time, numerous devices appeared to apply warm material to the root canal. The filling material could be plasticized in the root canal or introduced into the canal in a plasticized form.

There are many devices for plasticizing the material filling the root canal on the market. However, the leaders are dominant, among which undoubtedly is the filling system consisting of two devices: System B (Sybron Endo,Madrid, Spain) and Obtura III (Obtura Spartan). Originally, only the Obtura I apparatus, first constructed in the 1980s, was used to fill the canals [342]. It is a device consisting of a basic part providing heat supply and a feeder in the form of a gun with a needle, through which the gutta-percha plasticized by heating is applied to the inside of the canal. This device has already lived to see its third generation.

System B, a hot plugger, is used to fill the top part of the canal, and the Obtura device completes the distal, paraventricular part of the canal. System B consists of a base unit and a plugger. This device uses vertical condensation of the material in the canal through a hot plugger [343-345].

The latest version, called the Elements Obturation Unit (SybronEndo, Madrid, Spain), combines two devices; i.e., System B and Obtura, taking up 70\% less space than its older counterparts, and additionally equipped with a cauter and enabling the pulp vitality test with a thermal test. The novelty lies in applying the material with a tip with a micro-motor, thanks to which the material is forced into the channel more smoothly than in older models, with a manually operated feeder.

The technique of root canal filling with the System B and Obtura system was presented by Buchanan [346] and called the continuous wave of condensation obturation technique, or CWT [347]. This method assumes, in the first place, the selection of the main cone that matches the size and conicity of the root canal. The fitted stud should wedge in the periapical area. Next, adjust the Buchanan plugger to the canal's diameter and mark its length with a limiter 4-7 mm shorter than the working length. The root canal walls should be covered with a thin layer of sealant, removing the excess with a paper filter. When starting System B, set the temperature to $200{ }^{\circ} \mathrm{C}$ and insert the heated plugger through the gutta-percha point in the root canal to the length marked with a limiter. After $3 \mathrm{~s}$, the heating is turned off, keeping the tool's pressure towards the root tip for $10 \mathrm{~s}$. During the change of the gutta-percha from liquid to solid, volumetric changes of the material occur. Therefore, the compression of the material compensates for the polymerization shrinkage. Then the plugger is reheated to $300^{\circ} \mathrm{C}$ and immediately removed along with any excess gutta-percha. The apical portion of the gutta-percha should be condensed for another 10 $\mathrm{s}$ with pulsating movements using a cold plugger. This apical-filled canal can be refilled using System B. It should be done in stages when refilling the canal, introducing small portions of liquid gutta-percha and condensing each time [348].

The thermo-hydraulic condensation (THC) technique (Figure 7) [174,349] with System $\mathrm{B}$ and Obtura is considered to be one of the best root canal filling methods, as all voids are closed with filling material, not sealant [350], concluding with the THC technique filling the lateral tubules along the entire length of the root canal. A novelty that ensures an even greater tightness of the canal filling is the provision of hot pluggers with a vibrating tip provided by the wireless DownPak device. The additional function of vibration is 
to improve the flow of thermoplastic gutta-percha into any voids formed, thus ensuring homogeneity of the filling.

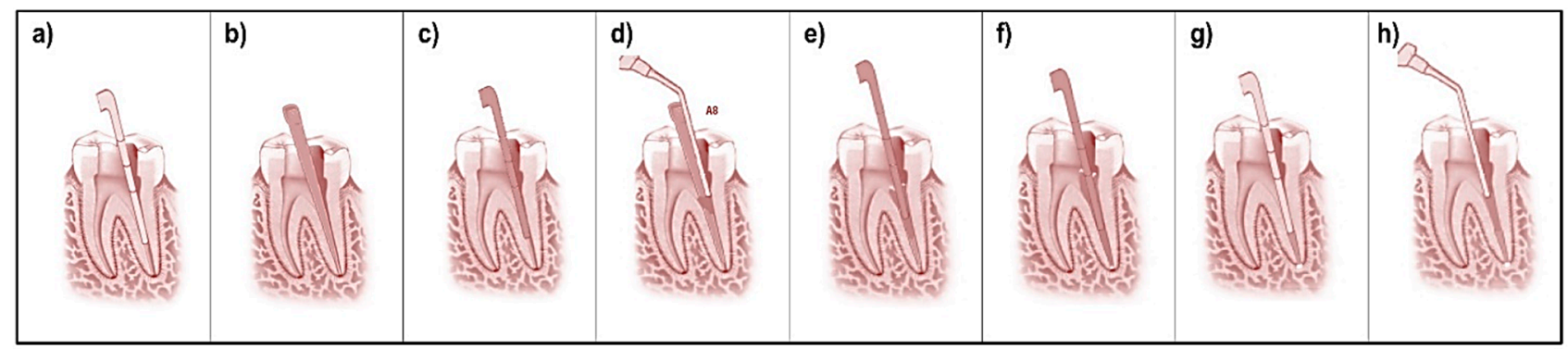

Figure 7. Scheme of successive stages of the original thermo-hydraulic condensation technique: (a) a Dovgan plugger is fit to 3-5 $\mathrm{mm}$ of the working length after appropriate root canal preparation; (b) a non-standarised gutta-percha cone is fitted $1 \mathrm{~mm}$ short of the working length; (c) a Buchanan plugger is prefitted in the canal to bind within 4-7 mm from the apical terminus; (d) using the tip of the Obtura gun, thermoplasticized gutta percha is injected into the canal and the head of the cone is seared off at the orifice; (e) the Buchanan plugger (preheated to $100{ }^{\circ} \mathrm{C}$ ) is driven into the gutta-percha until resistance is felt; (f) the System B apical is applied to the plugger until binding resistance is felt after the temperature is raised to $300{ }^{\circ} \mathrm{C}$ (the plugger is then immediately withdrawn); (g) to condense the thermosoftened gutta-percha, an up/down motion is used with the prefitted Dovgan plugger with firm pressure for $10 \mathrm{~s}$ as the material cools; (h) the obturation is completed using the Obtura gun by backfilling the canal.

Another very popular method for filling root canals is the Thermafil system. This method was described in 1978 by Johnson, and its widespread use was noted in the early 1990s [341,351,352]. The entire system was developed by Dentsply and consisted of: root canal preparation tools, compatible obturators in the form of conveyors made of polymeric material covered with gutta-percha material, verifiers to determine the appropriate size of the gutta-percha conveyor and a device for heating the gutta-percha; i.e., the ThermaPrep Plus oven. The procedure for filling the canal with the Thermafil system is limited to selecting the appropriate size of Thermafil gutta-percha with the help of a verifier. The verifier should slide to its full length without any force exerted on it, and is selected using the last tool used to work at full working length as an index. After choosing the appropriate obturator, it is necessary to mark the working length with a stopper, disinfect it in a sodium hypochlorite solution, then dry it and place it in an oven to plasticize it. Before filling, the canal should be dried, and the sealant should be applied to its walls. The gutta-percha material plasticized on the conveyor should be placed in the canal for the previously marked working length, maintaining constant pressure on the plastic carrier for a few seconds. It should be cut off with a Therma-Cut drill, without a spray, and the gutta-percha should be condensed around the carrier with a plugger [353-355]. The Thermafil system is considered to provide a good seal, especially in the apical area, due to the good fit of the carrier in the apical area of the root.

Unfortunately, this system has a high percentage of material pushed beyond the physiological opening [356]. It was also found that the sealant of Thermafil root canal fillings deteriorates in teeth with long roots. The use of the system is also limited by wide canals terminating in very wide apical openings [356].

Taking into account the results of our own virtually performed analysis [70] and the conducted literature review, the experimental studies in this paper included variants of root canal obturation by lateral condensation of gutta-percha, using the Thermafil system and the thermo-hydraulic condensation (THC) technique with the use of System B and Obtura, compared with the standard cold side condensation method.

\section{Selection and Description of the Scope and Methodology of Experimental Research}

To achieve the research goals set out in this paper, the so-called "digital twins" as an approach characteristic of Industry 4.0 [357-383] and the resulting idea of Dentistry 
4.0 [384-386] were applied. The "digital twin" concept allows many experiments to be carried out in virtual space before the analyzed product or object is physically created or made available for research, even without its physical existence. Experimental verification of the solution or variant selected virtually as the most advantageous is sufficient due to the set of considered criteria. To solve the issues constituting the essence of this paper, the methodology and research results, developed and published in the authors' own works on surface engineering technologies [70,361,387-401], were appropriately adapted. An open and synergistic methodological approach was adopted, specific to various and seemingly very distant scientific disciplines of clinical dentistry, especially endodontics in its part; materials engineering, including metallography and scanning electron microscopy; engineering and knowledge management, including the methodology of technological foresight and procedural benchmarking; and comparative analysis with the use of contextual matrices. Therefore, appropriate laboratory tests were preceded by the theoretical analysis carried out in [70] using the methods mentioned above. The methodological assumptions of the virtual comparative analysis of biomaterials used in endodontic treatment were presented in great detail. The basis of the considerations and research undertaken in this paper is a detailed analysis of all factors contributing to the effectiveness of endodontic treatment. It should be noted that 8 years after the end of root canal treatment, statistically, $97 \%$ of teeth retain their functional utility in the oral cavity [402]. About 3\% of endodontic failures, most of which are revealed within the first three years after treatment, are due to improperly filled root canals or from iatrogenic causes such as root or crown fractures [402-405]. Endodontic treatment may also result in undesirable granuloma or cystic periapical changes in the teeth [406] detected on X-rays during follow-up examinations. The risk of periapical lesions decreases with increasing accuracy of root canal filling and pillar reconstruction [107]. As much as $91 \%$ of periapical changes in endodontically treated teeth, revealed on panoramic photos, are caused by irregularities in the root canal filling [406] and inaccurate preparation and filling of root canals [107,406-415]. Therefore, great emphasis should be placed on the quality of root canal preparation and filling, in order to significantly reduce the chance of complications in the form of periapical lesions, and thus guarantee success in endodontic treatment. The article [70] presents the results of virtual analyses considering the basic factors determining the success of endodontic treatment, in the form of four types of proprietary contextual matrices for endodontics (listed in Table 1).

Table 1. Types of contextual matrices related to endodontics.

\begin{tabular}{|c|c|c|c|}
\hline No. & $\begin{array}{c}\text { Type of Context } \\
\text { Matrix }\end{array}$ & $\begin{array}{c}\text { Generalized Index on } \\
\text { the } x \text { Axis }\end{array}$ & $\begin{array}{c}\text { Generalized Index on } \\
\text { the y Axis }\end{array}$ \\
\hline A1 & Materials selection & $\begin{array}{l}\text { generalized index of } \\
\text { material quality for root } \\
\text { canal filling }\end{array}$ & $\begin{array}{l}\text { generalized index of } \\
\text { material strength in the } \\
\text { root canal }\end{array}$ \\
\hline $\mathrm{A} 2$ & $\begin{array}{c}\text { Root canal } \\
\text { development } \\
\text { technique selection }\end{array}$ & $\begin{array}{c}\text { generalized } \\
\text { organizational index of } \\
\text { techniques for the } \\
\text { development of root } \\
\text { canals }\end{array}$ & $\begin{array}{l}\text { generalized index of the } \\
\text { quality of filling with } \\
\text { selected techniques }\end{array}$ \\
\hline A3 & $\begin{array}{l}\text { Techniques of } \\
\text { obturation selection }\end{array}$ & $\begin{array}{c}\text { generalized index of } \\
\text { material strength applied } \\
\text { in root canal obturation } \\
\text { techniques }\end{array}$ & $\begin{array}{l}\text { generalized index of the } \\
\text { effectiveness of root canal } \\
\text { obturation techniques }\end{array}$ \\
\hline A4 & $\begin{array}{l}\text { Assessing the } \\
\text { tightness of root canal } \\
\text { filling selection }\end{array}$ & $\begin{array}{l}\text { generalized index of } \\
\text { organizational conditions }\end{array}$ & $\begin{array}{l}\text { generalized index of } \\
\text { investigations } \\
\text { effectiveness }\end{array}$ \\
\hline
\end{tabular}


The results of virtual analyses achieved in the authors' work [70] made it possible to determine the purpose of the research undertaken and discussed in this paper. Following the results of [70], in this paper, practical research was carried out on the manufacturing and selection of filling and sealing materials; the selection of dental devices and tools, including specialized tools; the selection and use of root canal development and obturation technology; and the assessment of the effectiveness and tightness of the root canal filling, as a result of endodontic treatment. The developed methodology was adopted for detailed research based on the analyses performed and the dendrological matrices plotted, constituting the basis for making decisions regarding the detailed studies covering the four aspects mentioned above, with a very limited number of factors, which should also be taken into account in the experimental research.

Experimental research was carried out to answer several research questions of various importance, which seem to constitute the most important problems of modern, highly advanced endodontics, including:

- Clinical-how to choose the conditions for the development and obturation of root canals;

- Technological - which of the methods used for the development and obturation of root canals ensures the best tightness of the filling;

- Methodological-what research methods are most useful for the assessment of the effectiveness of endodontic treatment; and

- Scientific - why there is a difference in the tightness of the filling between the root canal wall and the filling material, depending on the adopted root canal preparation and obturation method.

The tests were performed in vitro using 48 single-canal incisors in the maxilla, maxillary, and mandibular canines, and single-canal premolars of the maxilla and mandible removed for orthodontic, prosthetic, and periodontal disease indications without caries. The research was carried out after obtaining the consent of the Bioethics Committee. Table 2 summarizes the conditions and methods of preparing teeth for examination and methods of developing root canals.

Table 2. Conditions and methods of teeth preparation for examination and methods of tooth root canal preparation.

\begin{tabular}{|c|c|c|c|}
\hline No. & \multicolumn{2}{|c|}{ Type of Action } & Description of the Action \\
\hline B1 & \multicolumn{2}{|c|}{ 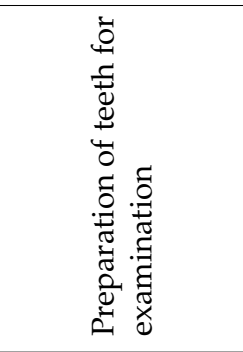 } & $\begin{array}{l}\text { Before processing, each tooth was cleaned and rinsed in } 0.9 \% \mathrm{NaCl} \text { solution, and then the tooth } \\
\text { crowns were cut off at the height of the tooth neck with a diamond separator placed on the } \\
\text { prosthetic handpiece. During the mechanical preparation of the root canals, a lubricant } \\
\text { containing glycerin, sodium edetate, and urea peroxide RC-Prep (Premier) was used. The task of } \\
\text { the lubricant during the preparation of the canal was to remove the smear layer covering the } \\
\text { canal dentin and to facilitate the mechanical preparation of the canal with the tools used. } \\
\text { Between each instrument subsequently introduced into the root canal, irrigation with } 2.25 \% \\
\text { sodium hypochlorite solution and } 0.9 \% \text { saline solution was performed alternately. }\end{array}$ \\
\hline B2 & \multirow{2}{*}{ 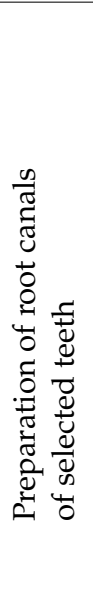 } & 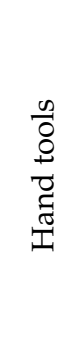 & $\begin{array}{l}\text { Each canal in a given group was prepared with hand tools (ProTaper-Dentsply/Maillefer) in } \\
\text { two stages; in the first stage, the near-crown part was widened with the S1 tool; successively, the } \\
\text { SX tool with the highest } 19 \% \text { taper was introduced into the same part of the canal, after which the } \\
\text { length of the canal was measured with a Kerr file with the number } 10 \text { ISO, from which } 1 \text { mm has } \\
\text { been subtracted. The working length was determined based on the length of the tooth canal } \\
\text { minus } 1 \mathrm{~mm} \text { (as the average distance between the anatomical apex and the physiological } \\
\text { narrowing of the root canal). The channel was subsequently developed to the full working length } \\
\text { with the S1 and S2 tools. The next four tools, numbered F1, F2, F3, and F4, were introduced to the } \\
\text { full working length, widening, and smoothing the root canal walls. Each tool introduced was } \\
\text { followed by a canal recapitulation with the Kerr tool. }\end{array}$ \\
\hline B3 & & 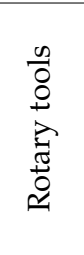 & $\begin{array}{l}\text { Each canal in a given group was prepared with rotary tools up to the size of ISO } 40 \text { using the } \\
\text { X-Smart endodontic micromotor (DentSply / Maillefer with K3 tools (Sybron Endo)). Each canal } \\
\text { was prepared in two stages, } 10 / 25 \text { and } 08 / 25 \text {, with a taper of the tool of } 10 \text { and } 8 \% \text {, respectively. } \\
\text { Then, the root canal length was measured by inserting a } 10 \text { ISO Kerr file and subtracting from the } \\
\text { full length of } 1 \mathrm{~mm} \text {, determining the working length as the average distance between the } \\
\text { anatomical apex and the constriction. Then, the canal was prepared to its full working length } \\
\text { with tools in sizes of } 0.4 / 20,0.4 / 25,0.4 / 30,0.4 / 35 \text {, and } 0.4 / 40 \text {. }\end{array}$ \\
\hline
\end{tabular}


Among the examined teeth, three groups were distinguished, each of which contained 16 teeth Each of these groups was tested under identical conditions of root canal preparation, using the same filling materials and using the same obturation technique.

Table 3 lists the methods of root canal obturation. In all cases considered in this paper, cones and pellets of material based on gutta-percha were used for filling. Hand and rotary tools were used to prepare the root canal. Three methods of obturation by cold side condensation, the thermoplastic technique, and the thermo-hydraulic condensation technique [172-177] introduced about 20 years ago were compared. In many of the cited studies, methodological defects were found that prevented an objective assessment of the tightness of the filling and the absence of leaks. For this reason, the basic materialography tests with the use of scanning electron microscopy were used, the usefulness of which was previously fully confirmed by virtual methods [70].

Table 3. Methods of root canal obturation.

\begin{tabular}{|c|c|c|}
\hline No. & Method & Description of the Method of Filling the Root Canals \\
\hline $\mathrm{C} 1$ & 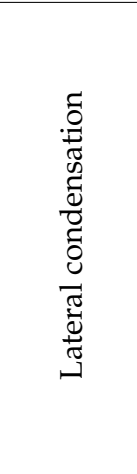 & $\begin{array}{l}\text { Each channel in a given group was filled with studs and pellets. After drying the root canal, an F4 } \\
\text { size pin (DentSply /Maillefer) was fitted, corresponding to the last tool used to prepare the canal to } \\
\text { the full working length. Before obturation, each canal was thoroughly dried with paper points. A } \\
\text { thin layer of sealant (AH Plus type-DentSply /Maillefer) was applied to the walls with a paper filter } \\
\text { in each canal. Each stud was disinfected in } 2.25 \% \text { sodium hypochlorite solution, and then placed in } \\
\text { the root canal on the full, previously determined working length. Due to the large convergence of the } \\
\text { main cone, which corresponded to the variable convergence of the ProTaper type tool, an expander } \\
\text { with the size of } 20 \text { ISO, and with a convergence of } 2 \% \text {, was selected. Using a silicone stopper, a length } \\
1 \mathrm{~mm} \text { shorter than the length on which the main stud was inserted was determined on the plunger. } \\
\text { After the placement was prepared by the manual pusher, the canal was supplemented with studs } \\
\text { with a taper of } 2 \% \text { in the size corresponding to the pusher used. The filling of the channel was } \\
\text { completed when it was not possible to introduce the plunger into the channel. }\end{array}$ \\
\hline $\mathrm{C} 2$ & 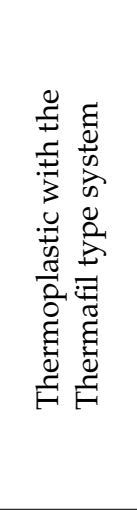 & $\begin{array}{l}\text { Each channel in a given group was filled with studs and pellets. The use of the system began with } \\
\text { the inspection of the canal with a } 40 \text { ISO verifier, the size of the last instrument introduced during } \\
\text { root canal preparation. After selecting the appropriate obturator, the working length was marked } \\
\text { with a stopper, then it was disinfected in a } 2.25 \% \text { sodium hypochlorite solution, dried, and placed in } \\
\text { a ThermaPrep Plus oven to plasticize it. In each channel, a thin layer of AH Plus sealant } \\
\text { (DentSply/Maillefer) was applied to the walls with a paper filter. After the gutta-percha was } \\
\text { plasticized in the oven, the obturator was slowly withdrawn from the lift of the oven and placed in } \\
\text { the channel for the working length previously indicated, maintaining a constant pressure on the } \\
\text { polymer support for a few seconds. When placing the obturator, care was taken that it was precisely } \\
\text { centered into the canal to prevent distortion of the gutta-percha matrix at the top of the obturator. } \\
\text { The polymeric material carrier on the gutta-percha matrix was then cut off with a Therma-Cut drill } \\
\text { without water cooling at } 300,000 \mathrm{rpm} \text {, and the gutta-percha matrix material was condensed around } \\
\text { the carrier with a plunger. }\end{array}$ \\
\hline $\mathrm{C} 3$ & 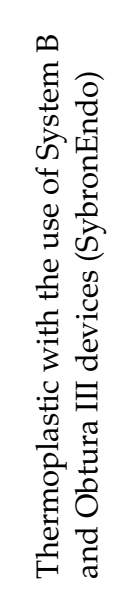 & $\begin{array}{l}\text { Each channel in a given group was filled with studs and pellets. The root canals were thoroughly } \\
\text { dried with paper points, then the main pin with a convergence of } 4 \% \text { was selected; the selection } \\
\text { criterion was the wedging of the pin in the periapical area after it was introduced to its full working } \\
\text { length. A Buchanan plugger (SybronEndo), size } 1 \text {, was subsequently fitted to the canal's diameter, } \\
\text { and its length was marked with a stopper, equal to the working length shortened by } 4 \mathrm{~mm} \text {. The root } \\
\text { canal walls were covered with a thin layer of AH Plus sealant (DentSply / Maillefer) with a paper } \\
\text { filter. During the introduction of the heated System B plugger through the stud placed in the root } \\
\text { canal up to the length marked with a stopper, the temperature was set at } 200^{\circ} \mathrm{C} \text {. After } 3 \mathrm{~s} \text {, the } \\
\text { heating was turned off while maintaining the pressure of the tool towards the root apex for } 10 \mathrm{~s} \text {. The } \\
\text { plugger was then reheated to } 300{ }^{\circ} \mathrm{C} \text { and immediately removed along with any excess uncondensed } \\
\text { material. The apical portion of the material was condensed with pulsating movements for the next } \\
10 \text { s using a cold, previously selected Buchanan-type plugger (SybronEndo). The canal, filled in this } \\
\text { way, at the apex, was filled with gutta-percha matrix material and fed into the canal with the use of } \\
\text { an Obtura III type system (SybronEndo) with a temperature set at } 160^{\circ} \mathrm{C} \text {. The canal was restored in } \\
\text { stages, introducing small portions of liquid material, condensing each time with a Buchanan-type } \\
\text { plugger (SybronEndo). }\end{array}$ \\
\hline
\end{tabular}


Table 4 contains information on the method of preparation of specimens for the assessment of the effectiveness of filling root canals and identifying possible leaks, as well as the methods of the materialographic tests used.

Table 4. Methods of preparing specimens and methods of materialographic research to evaluate the effectiveness of root canal filling.

\begin{tabular}{ccc}
\hline No. Type of Activity & Methods of Specimen Preparation or Materialographic Test Methods \\
\hline & To prepare the specimens for materialographic tests, after tight-filling the canals with each \\
technique, the root canal orifices of the selected teeth were secured with Ketac Molar glass \\
ionomer cement (3M ESPE). For the next 7 days, the teeth were stored in a humid environment \\
and room temperature to bind the sealant. Each tooth was wrapped in gauze soaked in \\
physiological saline and tightly closed in plastic containers.
\end{tabular}

The prepared specimens were incised longitudinally along the root to a depth of $1 \mathrm{~mm}$ using a diamond disc placed on a prosthetic handpiece. The research material was placed in liquid nitrogen and then a breakthrough was made. Each sample, after making longitudinal cuts by breakthroughs in liquid nitrogen, was then sputtered with a thin layer of gold as a conductive material in a BAL-TEC SCD050 sputtering machine by Oerlikon Balzers (Balzers,

Liechtenstein), to remove the electric charge from the surface of the specimen during the examination in the scanning electron microscope, as well as to improve the secondary electron emission factor.

Teeth filled with material based on gutta-percha were decalcified by immersion for 14 days in an aqueous solution consisting of $7 \%$ formic acid, $3 \%$ hydrochloric acid, and $8 \%$ sodium citrate. The specimens were then rinsed thoroughly under running water to eliminate the acid, and then immersed in $99 \%$ acetic acid for $12 \mathrm{~h}$, and then the specimens were rinsed thoroughly with distilled water. Then, the specimens were dehydrated in ethanol solution of successively increasing concentrations of 25,50,70,90, 95, and $100 \%$, each for $30 \mathrm{~min}$. Then the specimens were stored in methyl salicylate and observed in a Stereo Discovery V12 stereoscopic light microscope with the AxioCam HRC digital camera by Zeiss at 8-50× magnification, to the three-dimensional observation of the root canal lumen filled with a substitute material, with careful consideration of the root delta and its complicated internal system and side branches of the main canal.

Teeth filled with material based on gutta-percha were cut in the longitudinal and transverse directions using the GATAN ISOTOM device, and the materialographic specimens were made D4 by mounting in a thermosetting resin and mechanical grinding successively on abrasive papers with smaller and smaller grain size in Struers devices, and then on diamond pastes of granularity to $3 \mu \mathrm{m}$ for observation with a Leica $8 \mathrm{i}$ light microscope. D5 $\quad \begin{aligned} & \text { Initial tests were performed on the Stereo Discovery V12 stereo microscope with the AxioCam } \\ & \text { HRC digital camera by Zeiss; the test results were documented using the digital photography }\end{aligned}$ method at $50 \times$ magnification.

Tests were carried out using a SUPRA 35 high-resolution scanning microscope by Zeiss with a magnifications of 2000 and $5000 \times$, and the test results were digitally archived.

Observations were made using an AFM XE-100 atomic force microscope (AFM) by Park of an atom.

Observations were made in an Exciter confocal laser scanning microscope based on the Axio Observer microscope by ZEISS, with electronic recording of the test results.

Table 5 lists seven criteria for evaluating the research material depending on the variants of root canal development and obturation. 
Table 5. Criteria for the evaluation of the research material depending on the variants of development and obturation of the root canal.

\begin{tabular}{ccc}
\hline No. & Structure Assessment Elements & Used Microscopes \\
\hline 1. & Connection of the filling material with the dentin of the root canal & \\
2. & Connection of the main stud with complementary material & LSM-light \\
3. & Filling the side tubules & stereoscopic; \\
4. & Filling the root delta & SEM-scanning \\
5. & Connection of the material with the dentin tubules & electron \\
6. & Volume fraction of sealant & \\
7. & Leakage on the border of the root canal wall and the filling material & \\
\hline
\end{tabular}

\section{Results of Experimental Research and Their Discussion}

Our own research with a stereoscopic light microscope (Figure 8a-e), especially in specimens prepared by decalcification (Figure $8 \mathrm{f}-\mathrm{i}$ ), shows the complicated tubular system of the root canal, which consists of the central canal, accessory tubules, and root delta.

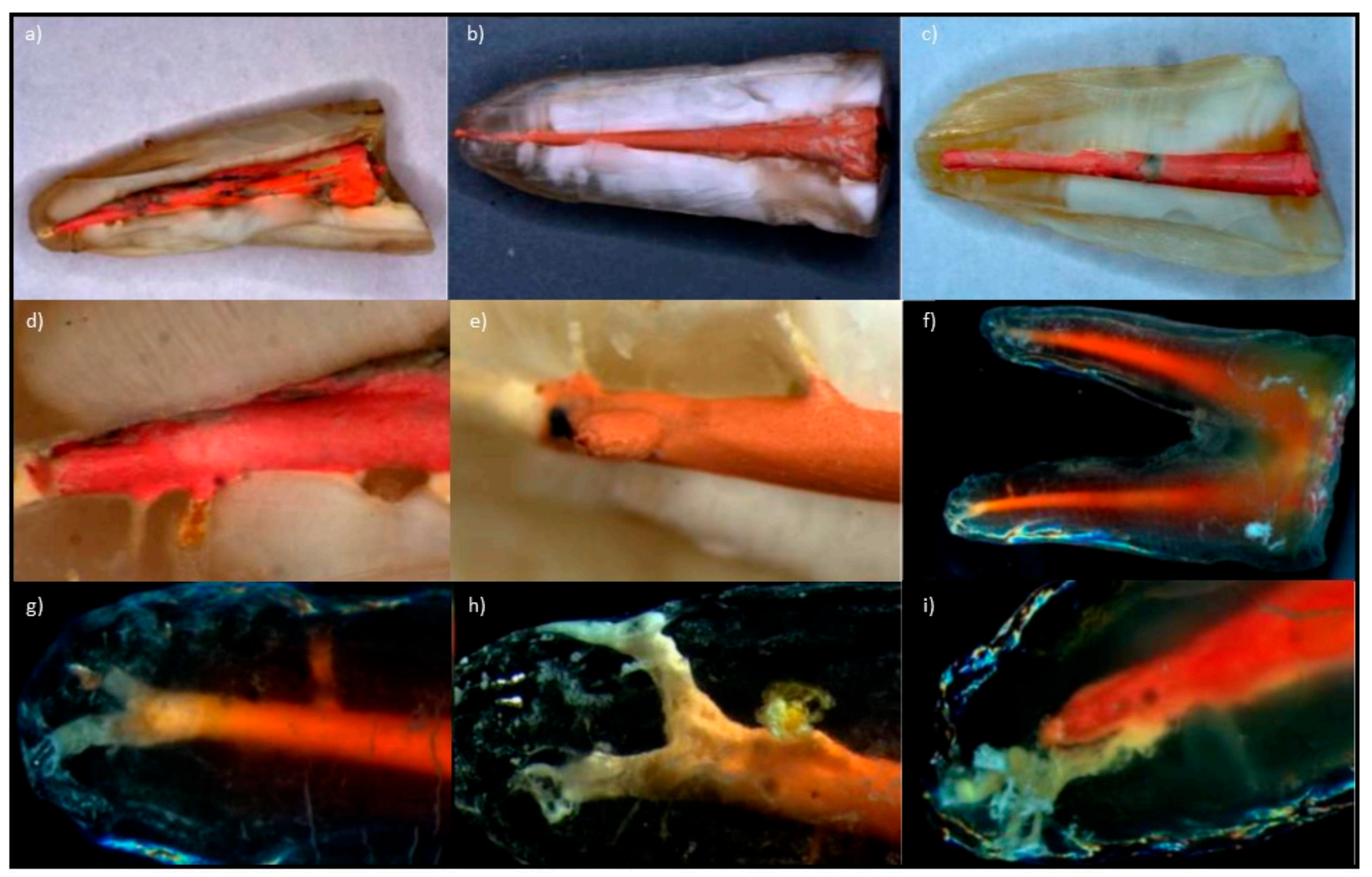

Figure 8. View of the tooth roots: (a-c) longitudinal breakthrough of the tooth root filled with gutta-percha material and sealant: (a) cold, (b) thermoplastically with a plasticizer, and (c) thermoplastically with THC; (d,e) lateral tubules in the apical part of the root canal filled with material based on a gutta-percha: (d) first at the apical side filled with sealant, and (e) both centrifugally filled with sealant; $(\mathbf{f}-\mathbf{i})$ teeth prepared by the decalcification technique: (f) two-root tooth with a root delta in each root, $(\mathbf{g}-\mathbf{i})$ and root canal delta filled with sealant viewed with an LSM.

Using a scanning electron microscope, the presence of even smaller anatomical structures, such as dentinal tubules, was also indicated (Figure 9). Since the condition expected by the dentist undertaking endodontic treatment, as well as by the patient, is the tightness of the connection of the filling material with the dentin of the root canal; i.e., the condition in which the components of the filling adhere exactly to each other, the basic 
criterion for a properly endodontically treated tooth, the internal space disinfection and tight three-dimensional hermetization, are assumed.

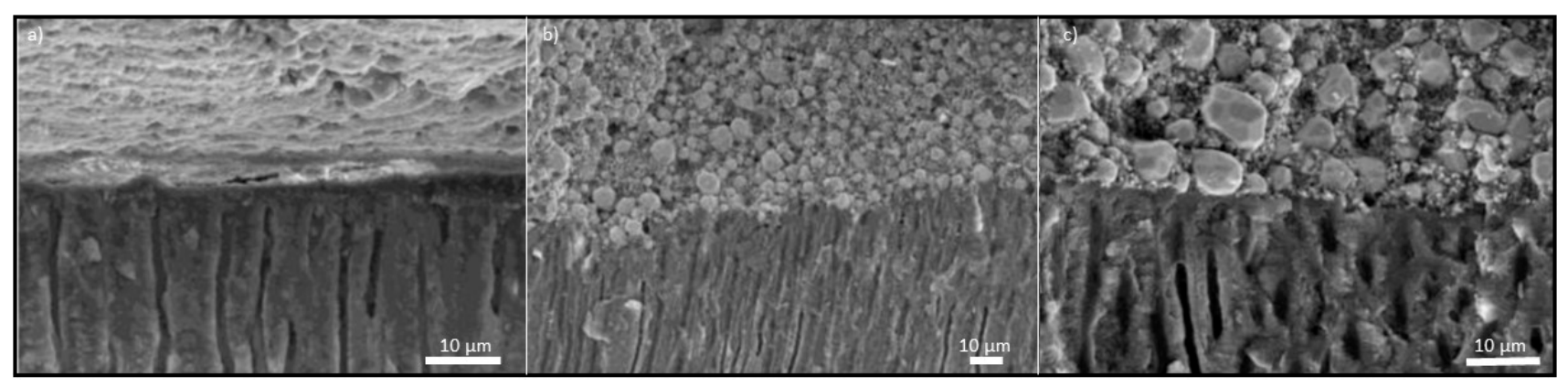

Figure 9. Close connection of the root dentin with a visible cross-section of the dentinal tubules along their axis transverse to the root canal with the filling material based on gutta-percha covered with an intermediate layer of sealant: (a) cold condensed; $(\mathbf{b}, \mathbf{c})$ thermoplastically condensed with THC, viewed with SEM.

For the assessment of these scientific achievements, the most important thing is to consider the quality of the connection of the filling material with the dentin of the root canal, which largely determines the tightness of the filling and the associated tightness of the root canal filling, and in practice, the low surface density of the leaks and their small size. As shown by the materialographic tests carried out, it strictly depends on the technology of preparation and obturation of the root canal and sealing materials used with gutta-percha, and their optimization allows the minimisation of the surface density of the leak and its size. Only hot thermoplastic obturation provides acceptable results in this respect, because there is a greater chance of three-dimensional obturation of the canal than in the case of cold methods due to the plasticized material flowing into the pits and niches that may appear along the entire length of the root canal, creating a close connection referred to in the literature as a monoblock (Figure 10).

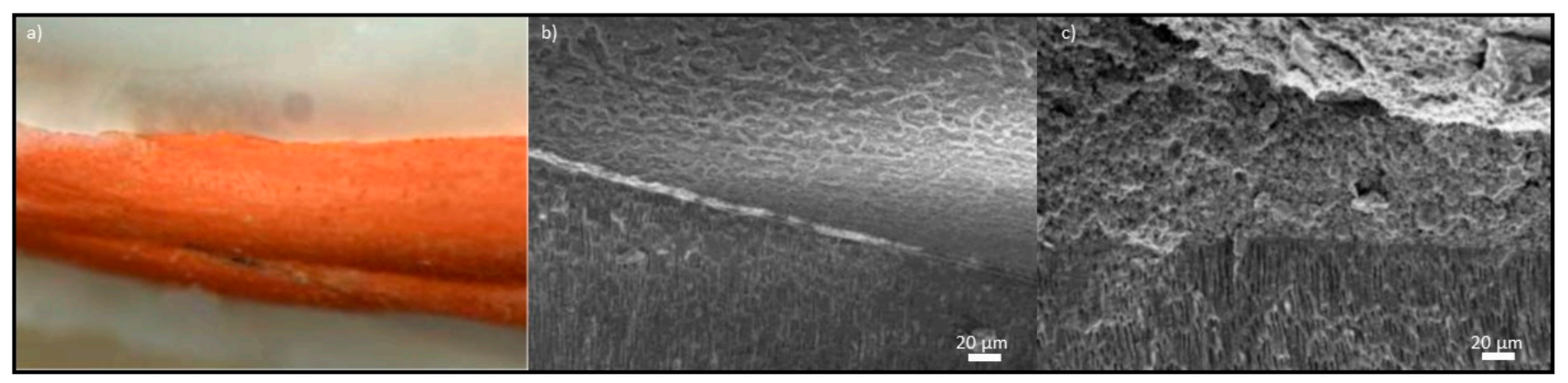

Figure 10. Tight connection of the material on the matrix of gutta-percha, evenly covered with an intermediate layer of sealant and the dentin of the root canal. $(\mathbf{a}, \mathbf{b})$ After thermoplastic condensation of the filling material: (a) longitudinal breakthrough, LSM; (b) visible course of the tubules, viewed using SEM; (c) after thermoplastic condensation with THC, the filling material has been placed with a visible cross-section of the dental tubules, viewed using SEM.

Only in the case of the methods of preparation and obturation of the root canal with the use of thermoplastically condensation THC technique, there is a correct, tight connection in each of the assessed sections of the root canal, confirmed by the results of examinations in a light stereoscopic microscope (Figure 11a) and in a scanning electron microscope (Figure 11b,c). The tight connection of the root dentin, sealant, and filling material, closing the mouths of the dentinal tubules and penetration into the lateral tubules and the root delta, partially with the filling material and the sealant, occurs only in the case of filling material based on gutta-percha with an appropriate sealant (Figure 8g-i). This was confirmed, among others, by the results reported in [124,131] after 14 or 16 months of follow-up, respectively. 


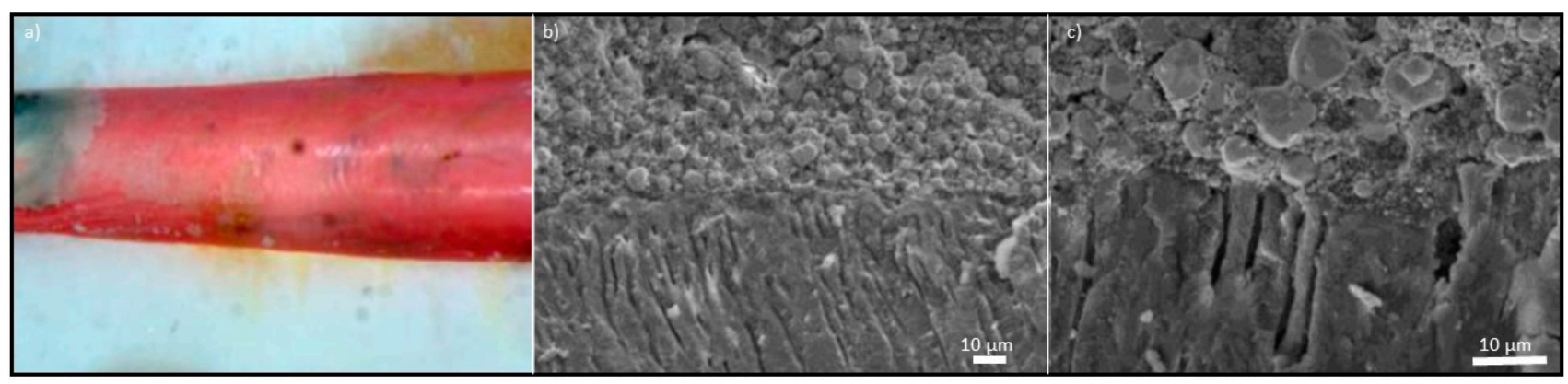

Figure 11. The borderline of the root canal wall, a thin intermediate layer of sealant and material based on a gutta-percha matrix of thermoplastic condensation with THC: (a) longitudinal breakthrough, viewed with LSM; (b,c) a visible crosssection of the dentinal tubules along their transverse to the axis of the root canal with the filling material covered with an intermediate layer of sealant, viewed with SEM.

As part of the authors' own research, a dependence was shown regarding filling the dentinal tubules with a replacement material, which concerned more filling material and less application techniques. Thus, it was found that the AH Plus sealant based on synthetic resins, used in all tested obturation techniques, could penetrate into the dentinal tubules due to its fine-particle structure (Figure 12).

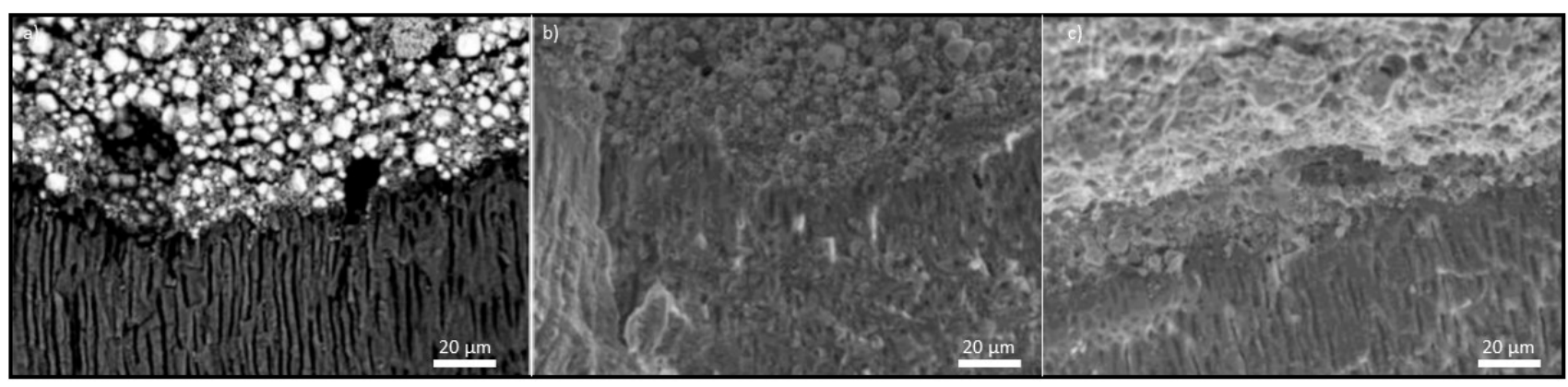

Figure 12. Fine particles of the sealant in the view of the longitudinal course of the dentinal tubules and the boundary with the tight connection of the sealant with the root canal wall: (a) thermoplastically condensed gutta-percha material, viewed with SEM-backscatter electron detector (BSD); $(\mathbf{b}, \mathbf{c})$ gutta-percha-based material thermoplastically condensed with the THC method, viewed with SEM.

It was also confirmed in previous studies [416] with a confocal laser microscope concerning filling the dentinal tubules with a sealant in the near crown, medial and apical sections, whereby this penetration was statistically shallower in the apical section than in the remaining sections of the root canal. Tight three-dimensional obturation of the root canal with a substitute material must not omit the filling of the spaces constituting the branches of the central canal, including lateral canals, and in the periapical area of the root delta canal system (Figure 13).

In the case of the thermoplastic condensation (or THC) method using System B and Obtura III, the filling material is based on a gutta-percha centrally in the central canal. In contrast, a sealant is used centrally in relation to the main canal (Figure 13). Therefore, our own research shows that both thermoplastic condensation methods can three-dimensional obturation of the root canal with filling its additional structures. In thermoplastic methods, the side canals are filled with a sealant and a material based on gutta-percha. Significant trends were also found regarding the distribution of the sealant and material in individual tubules distant from the root apex. So, the closer to the near-crown part, the more likely that the lateral canal will be filled with the material based on the gutta-percha in both thermoplastic condensation methods (Figures 8e and 13b). the main canal, and in the centre of the material based of the gutta-percha (Figure 8d,e and Figure 13b). On the 
other hand, directly apical, the side canals are filled only with sealant (Figure 13a). The results of our own research correspond with the observations in [343], which confirmed the filling of the lateral tubules and the root delta in $60 \%$ of all lateral cold condensation using the cold lateral tubule technique, and only with a sealant, and $83 \%$ in the thermoplastic condensation technique. Similar results were obtained in [348], which stated that $90.62 \%$ of the additional tubules and the root delta were filled in the THC thermoplastic condensation technique with the use of System B and Obtura III, while it was stated that, for the heat technique, these spaces were filled with both sealant and filling material based on guttapercha. It was also found that in the cold method, only the sealant filled the root delta and lateral canals, and in the thermoplastic condensation method, the root delta and lateral canals were filled both by the sealant and the material based on gutta-percha. The authors' own research confirmed the observations made there, indicating that significantly more filled side branches occurred in the case of obturation with thermoplastic condensation methods. Thermoplastic condensation techniques fill the additional spaces with both the sealant and the appropriate filling material. In the cold obturation technique, a relatively large share of the sealant tightly covered the filling material (Figure 14a,b). It was necessary to fix the studs together, so it needed to surround them. When its share between the main stud and additional studs was insufficient, non-connection of the material was observed (Figure 14a).
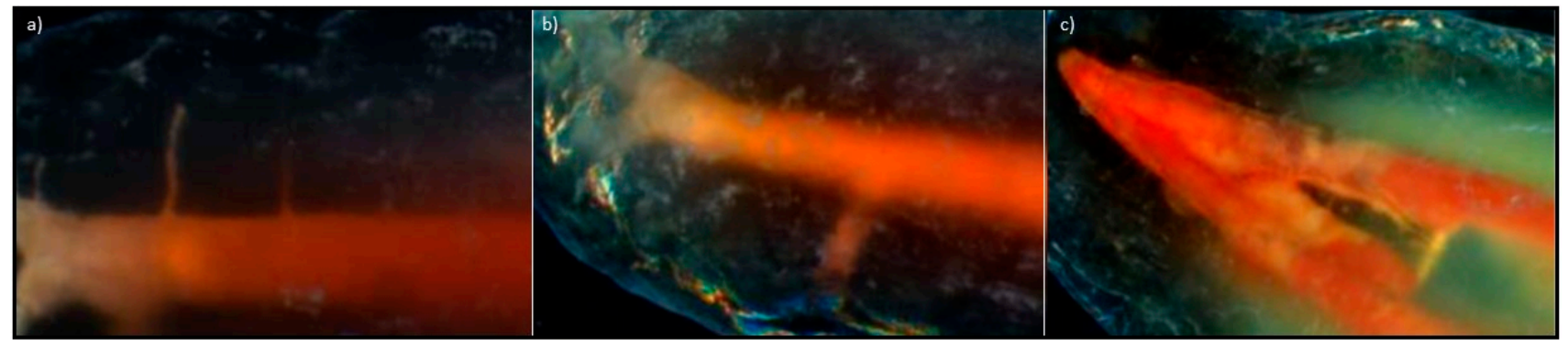

Figure 13. Lateral tubules in the research material subjected to decalcification, viewed with LSM: (a) in the apical part of the root canal, filled in the direction from the root apex, successively - the first with a sealant, the second with a gutta-percha substitute material centrally and centrifugally with a sealant, and the third with a gutta-percha substitute material; (b) single, in the apical part of the root canal, filled with replacement material based on gutta-percha; (c) single, connecting two main canals in the middle part of the tooth root filled with a sealant.

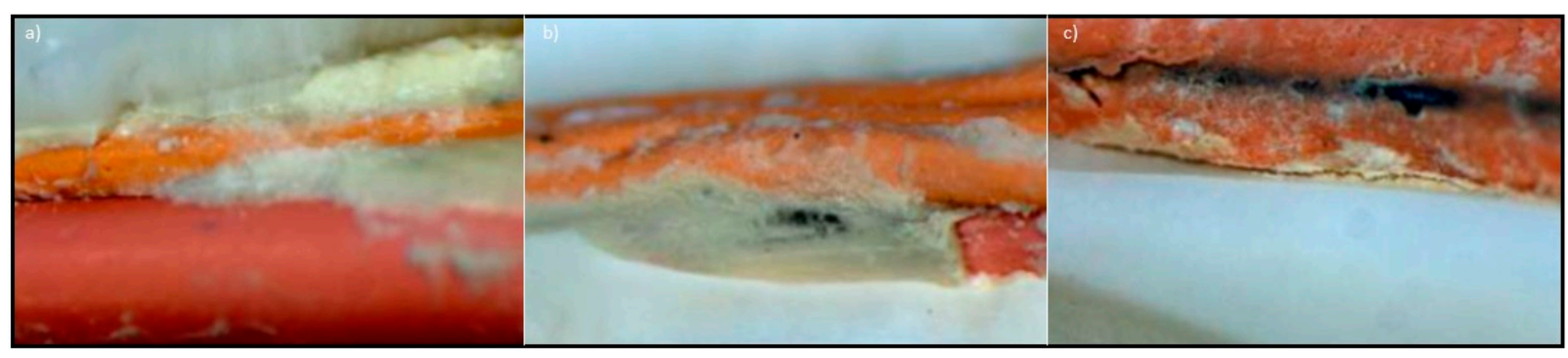

Figure 14. Middle section of the sealed root canal. $(\mathbf{a}, \mathbf{b})$ Cold: (a) thick intermediate layer of sealant on the border of the dentin of the root canal and complementary studs, and a thick intermediate layer of sealant on the border of complementary cones and central cone with visible leakage; (b) a thick intermediate layer of sealant covering the centre stud and additional studs adjacent to the main stud; (c) thermoplastically condensed-leakage on the border of the sealant and dentin, viewed with LSM.

It was also found that too thick of a layer of sealant caused its delamination and the separation of the filling material from the dentin of the root canal, also resulting in leakage (Figure 15). This was confirmed by the research in [344] on the volume of the sealant to 
the material based on gutta-percha in three application techniques, which showed that the highest proportion of the sealant of $12.10 \%$ occurs in the cold condensation technique. A large proportion of the sealant determines the formation of leaks on the boundary of the root canal wall and the filling material itself, i.e., the studs and the sealant.

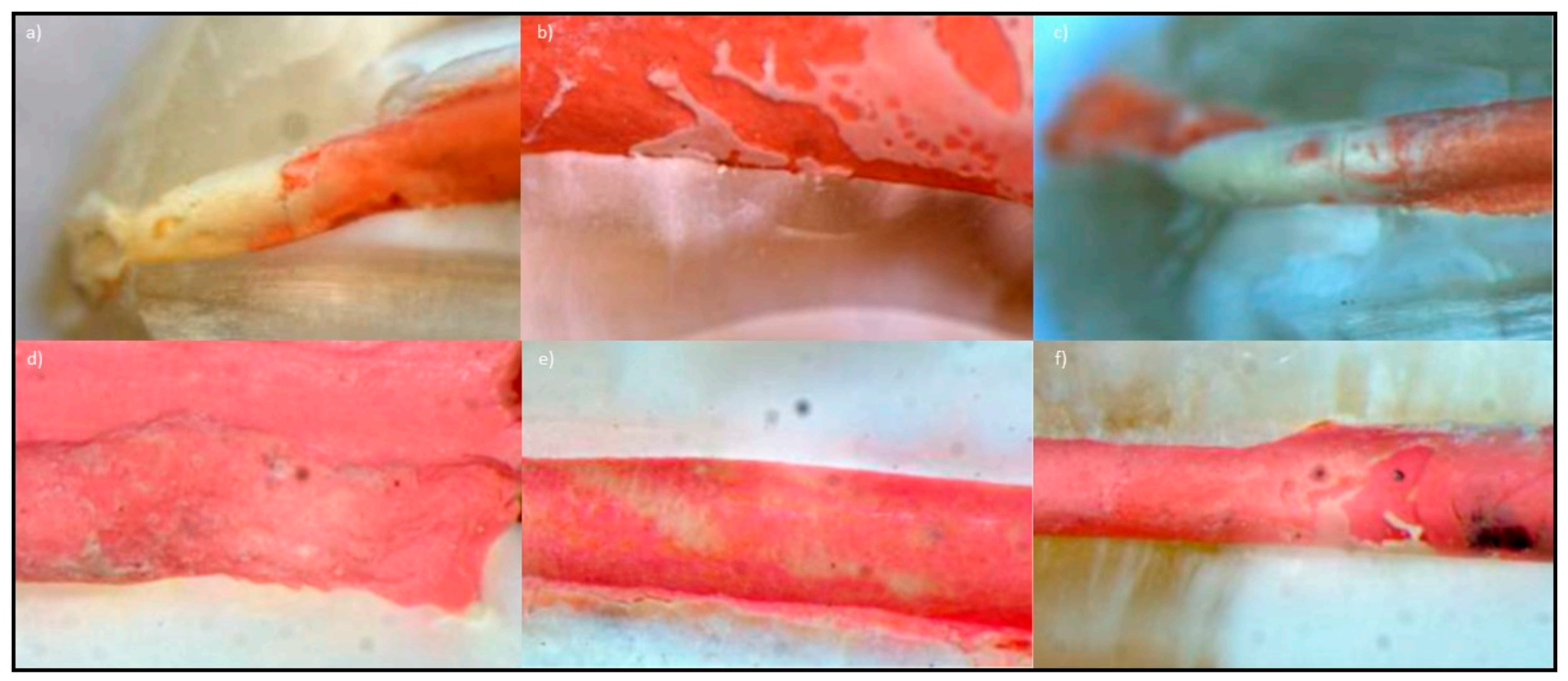

Figure 15. Longitudinal breakthroughs of teeth filled with material based on gutta-percha. (a-c) Thermoplastic obturation method: (a) accumulation of a thick intermediate layer of sealant in the apical area of the root canal; (b) uneven coverage of the material based on gutta-percha with a thin intermediate layer of sealant in the middle of the root canal; (c) accumulation of a larger intermediate layer of sealant in the apical region of the root canal. (d-f) THC thermoplastic obturation method: (d) a thin intermediate layer of sealant covering the material based on gutta-percha and bordering the root canal wall in the near-crown segment; (e) a thin interlayer of sealant completely covering the material based on gutta-percha in the apical region; (f) a thin intermediate layer of sealant covering the material based on gutta-percha and its greater accumulation in the centre of the root canal, viewed with LSM.

In both thermoplastic obturation methods, the sealant's volume share in relation to the proper filling material in the root canal was significantly lower than in the cold obturation method (Figure 15a,b). The presence of a tight monoblock of dentin, sealant, and the main filling material (Figure 15c) based on gutta-percha (Figure 15c-e) is also characteristic. Therefore, in the authors' own research, it was found that in the thermoplastic-obturation THC technique, the volume of the sealant was much smaller than in the cold technique.

However, when using the Thermafil obturator, it has been found that there was a significant build-up of sealant in the periapical area (Figure 15a-c), which was due to the apical movement of the sealant covering the canal wall through the obturator, which acted as a piston pressing against the less viscous structure. These observations were also made in [354,356]. At the same time, it was also shown [354] that overfilling the canal with Thermafil obturators did not translate into a tight connection of the root canal and filling material due to the leakage at the border between the material and the root wall, which was also confirmed by the authors' own research results. In the case of the THC method, the volume of the sealant was significantly lower in the authors' own research than in the case of cold obturation methods, and during the preparation of materialographic specimens, a smaller volume and fewer thrusts of the sealant were found than in the case of the Thermafil obturator. This was probably because in thermoplastic condensation methods, which use System B and Obtura III devices, the material is applied intrathecally in several portions so that a smaller volume of the sealant is pushed into the apical direction at a time. The condensation of small portions reduces shrinkage during material setting. Other observations concerning these two thermoplastic obturation techniques were demonstrated in [344], examining the volume fraction of the sealant in the 
System B + Obtura III method, which was 3.96\% of the total root canal volume, and $1.18 \%$ with the use of the Thermafil obturator. In addition, studies [417] on the effect of the sealant volume over time on the formation of marginal leakage show that two years after the sample was made, in which a sealant with a thickness of $0.3 \mathrm{~mm}$ was used, the leakage was significantly greater than in the group with a sealant with a thickness of $0.05 \mathrm{~mm}$. As part of our own research, it was shown that the presence of a tight monoblock of dentin, sealant, and the main filling material (Figure 15d,f) was associated with a sufficiently small share of the sealant, even described as a shiny coating covering gutta-percha as a proper filling material (Figure 15d,f). However, even in the case of heat obturation, a greater proportion of local sealant accumulations were found (Figure 15f). The authors' own observations concerning the share of the sealant, determined by the application technique and its influence on the leakage, indicated the advisability of reducing the share of the sealant to the thinnest possible layer (Figure 15f), which requires detailed optimization measures.

Even in the case of tight obturation of the root canal with the filling material based on gutta-percha, the THC method revealed gaps between the root dentin and the material based on gutta-percha covered with a sealant (Figure 16a-c) with a width of 1.061-8.131 $\mu \mathrm{m}$, respectively, and a leak on the border of the filling material, with no presence of a sealant and root dentin with a width of $2.828 \mu \mathrm{m}$ (Figure 16c). Leaks were also found in the layer of the sealant, on the one hand tightly connected with the root dentin, and on the other with the filling material (Figure 16d-f) with a width of 5.126-7.070 $\mu \mathrm{m}$, respectively.

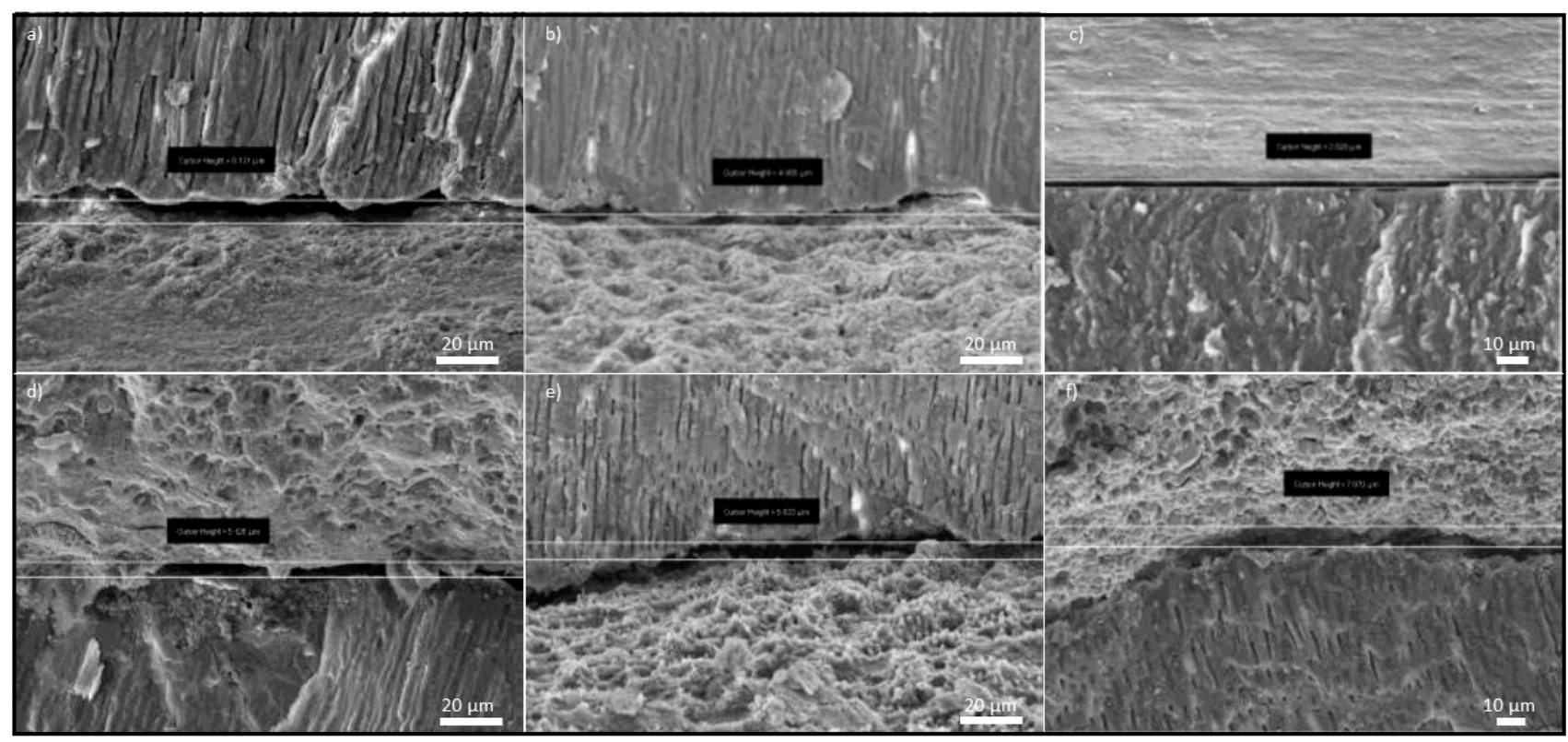

Figure 16. Leaks on the border of the sealant and dentin of the root canal filled with the THC thermoplastic condensation method with a width of: (a) $8.131 \mu \mathrm{m}$; (b) 4,065 $\mu \mathrm{m}$; (c) $1.061 \mu \mathrm{m}$; (d) $5.126 \mu \mathrm{m}$; (e) 5,833 $\mu \mathrm{m}$; (f) 7,070 $\mu \mathrm{m}$, viewed with SEM.

Preparation and obturation of the root canal with the THC method ensured, along the entire length of the root canal, an average value of the fissure width of $4.76 \pm 2.55 \mu \mathrm{m}$. These values differed for individual sections: $(4.88 \pm 2.75 \mu \mathrm{m})$ and apical $(2.33 \pm 1.41 \mu \mathrm{m})$ longitudinal breakthroughs (Figure 17). They were the smallest average values of the width of the slit for each of the three sections among all tested cases. The analysis of the significance level of differences between the width of the gaps in all analyzed sections for the entire root (Figure 17) showed that in all sections along the entire length, the differences between the THC method of root canal preparation and obturation and other methods were significant, which meant that it was precisely in this case that the best endodontic treatment results were obtained among all the preparation and obturation techniques analysed. 


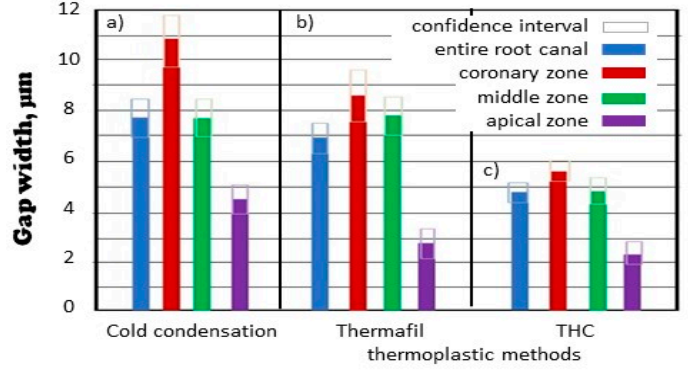

Obturation's methods

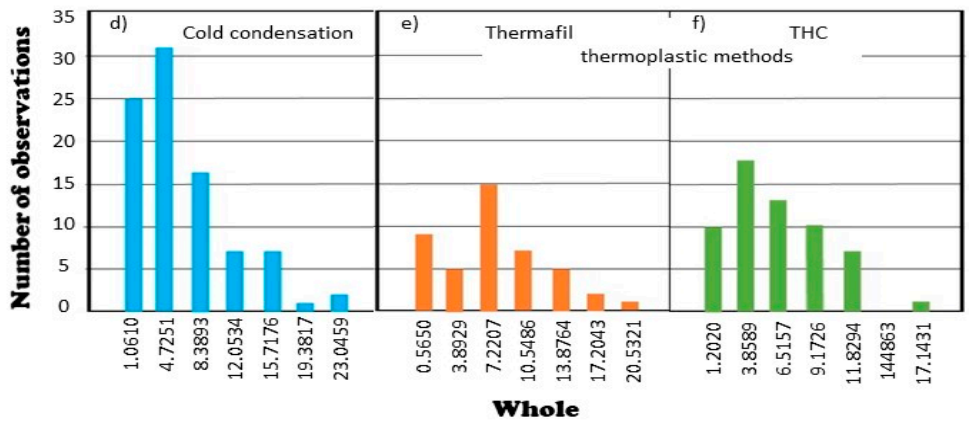

Whole

Figure 17. Generalization of the measurement results: $(\mathbf{a}-\mathbf{c})$ statistical analysis of the measurement results of the gap between the sealant and dentin of root canals filled with material based on gutta-percha; (d-f) histograms of the width of the gaps in the entire root canal after filling with the following methods: $(\mathbf{a}, \mathbf{d})$ cold; $(\mathbf{b}, \mathbf{c}, \mathbf{e}, \mathbf{f})$ thermoplastic condensation method with the use of: (b,e) Thermafil; $(\mathbf{c}, \mathbf{f})$ THC.

A method consisting of the preparation of root canals with K3 rotary tools (Sybron Endo) up to the size of 40 ISO using the X-Smart endodontic micro-motor (DentSply/Maillefer) in two stages, and the filling of the teeth with the THC thermoplastic obturation method using the System B and Obtura III devices (SybronEndo) with studs and pellets made of material based on gutta-percha after covering the root canal walls with a paper filter with a thin layer of AH Plus sealant (DentSply/Maillefer) showed the best results, both in terms of the gap width in all analyzed sections (Figure 18).

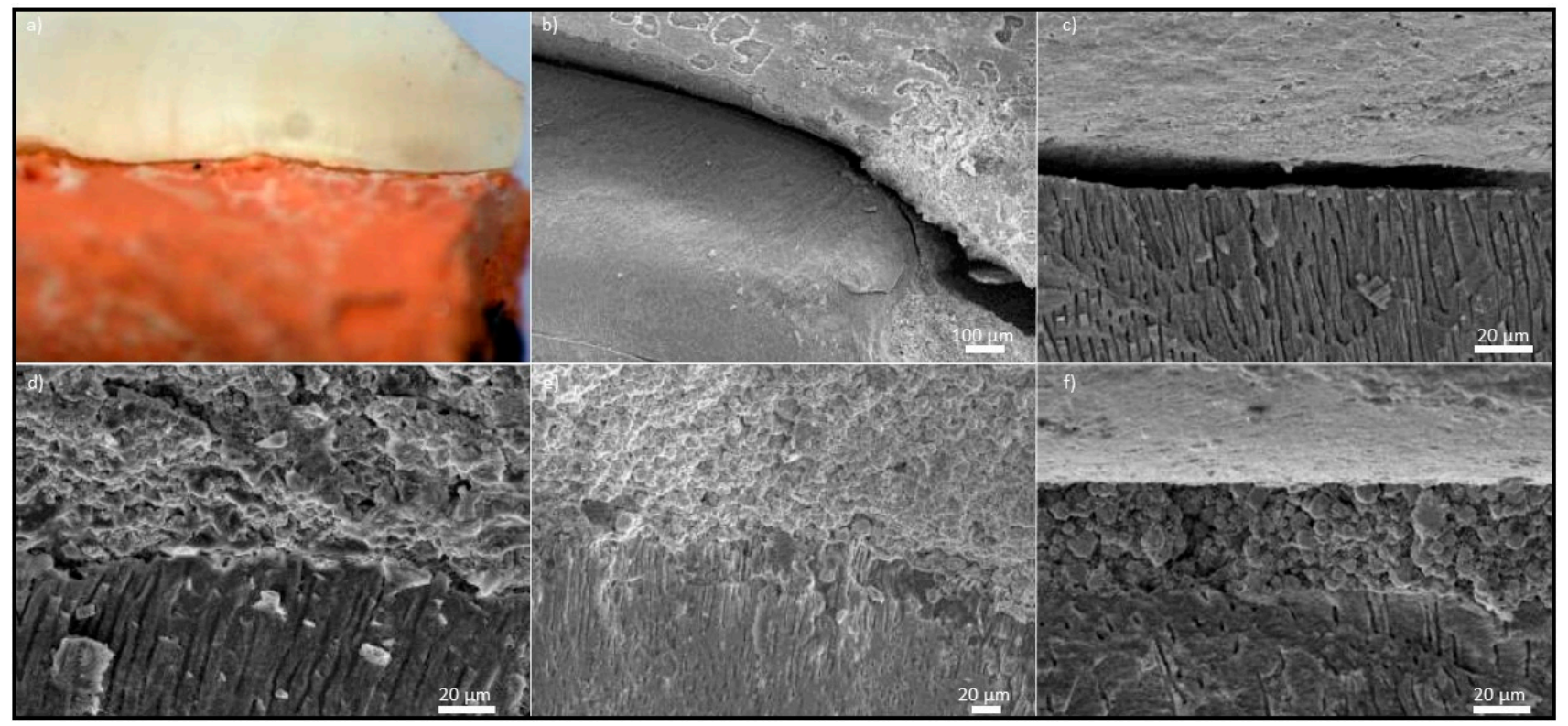

Figure 18. View: $(\mathbf{a}-\mathbf{c})$ leaks on the border of the sealant and dentin of the root canal filled with the thermoplastic condensation method: (a) in the near-crown section, viewed with LSM; (b) in the anatomical cavity of the central canal, viewed with SEM; (c) in the middle section, viewed with SEM. (d-f) Tight connections of material based on gutta-percha filled by cold condensation, covered with an intermediate layer of sealant and root canal dentin, viewed with SEM.

Even when using the Thermafil obturator in the apical segment, there was an average number of breakthroughs similar to the discussed THC method. Still, due to the much higher mean value of the fracture width in this segment, it was clear that the THC method showed significantly better results than other methods. In addition, the fact that when the THC method was used, there was a tight connection of the filling material with the root canal wall in each of its sections (Figure 18a,c), cannot put these obturation methods on par 
with the THC method, because the appearing gaps showed a greater density and a larger size of the gaps, which made these obturation techniques lower quality.

The method of cold obturation by lateral condensation using studs manufactured on material based on gutta-percha using appropriate sealants based on synthetic resin showed a much lower quality.

In this case, it was impossible to avoid gaps of relatively high density and size (Figure 18). The cause of leaks in the cold method can be considered, among others, the improper selection of the main cone concerning the prepared root canal. In this method, the manual ProTaper tools (Dentsply/Meillefer) were used to prepare the root canal, and for obturation, a main cone with a conicity of 0.4 and the material based on gutta-percha were used, and the tightness was worse than in the case of other methods. The authors' own research was not confirmed in [141], which examined the tightness with the color penetration test of root canals filled with, among others, materials on the matrix in cold side condensation, where a leakage equal to $0.89 \mathrm{~mm}$ was found when obturated with cones with a convergence of 0.4 , made of a material based on gutta-percha. It should be assumed that the lower obturation was determined by the selection of the tool for the preparation of the root canal with variable conicity and the selection of the main point for filling the root canal with a conicity of 0.4 , precisely matched to the hole made only in the apical area; therefore, it was necessary to use a larger number of additional points of the same sealant to a greater proportion. Increasing the chances of correct obturation by fitting the main cone with a convergence corresponding to the convergence of the developed canal in the single-cone method was confirmed in [418]. The views on tightness, especially in the apical area, were not consistent with this, presented in [338], in which it was found that the correct obturation in this section was influenced not so much by the wedging of the main stud in the apical area, but by the depth to which the plunger was introduced during lateral cold condensation, because when introducing the plunger to the full length of the root canal, a greater tightness was achieved than during insertion of the stripper to a depth $1 \mathrm{~mm}$ shorter than the working length. The results of the authors' own research on the tightness of the border between the filling material and the root dentin as the basic criterion for success in endodontic treatment indicated that the cold side condensation method caused leakage in all sections of the root canal, with a much higher value of the average width of the gaps in each section of the root canal compared to thermoplastic condensation methods.

All the included elements contribute to the tightness, which has been recognized as the basic criterion for the success of endodontic treatment. In the performed tests, the smallest average width of the fissures formed on the border of the root canal wall and the filling material was obtained using the THC method with a material based on gutta-percha and AH Plus sealant. This tightness was due to the close connection of the main cone with the complementary material, a thin layer of sealant closely covering the surface of the material, application of the material intrathecally in portions, thanks to which the plasticized material based on the gutta-percha had a chance to flow into the entire inner space of the root canal, including the lateral canals and the root delta, and thus had a chance to force a sealer of lower viscosity into the smallest anatomical structures; i.e., dentin tubules. The conducted research therefore allowed us to obtain answers to the research questions and to prove the hypothesis that the material based on gutta-percha is very useful in endodontics.

The results of materialographic tests performed in this paper on endodontically prepared and filled teeth using an automated stereoscopic microscope, a confocal laser microscope, a high-resolution scanning electron microscope, and an atomic force microscope confirmed the suitability of these methods and devices for the tests performed. It was indicated by all the drawings presented in this work and the signal results of the research presented in another of the authors' own works [70]. The most favorable results, including those due to the intuitive interpretation of the obtained images, were obtained using an automated stereoscopic microscope and a high-resolution scanning electron mi- 
croscope, and the obtained results are fully useful for supplementing the knowledge on the effectiveness of endodontic treatment. The implementation of the research mentioned above requires, however, extraordinary methodological diligence in the preparation of test preparations, which were prepared using available techniques; i.e., as transverse and longitudinal materialographic specimens, as well as fractures and longitudinal ones. Only some of these preparation techniques can be useful in the research of dental specimens. The attempt to prepare metallographic specimens of transverse and longitudinal tooth sections (Figure 19) was almost a complete failure, which practically eliminated the possibility of using them, often performed in basic tests; e.g., metal alloys. It was also evidenced by the blurred photos given in Figure 19b,c.

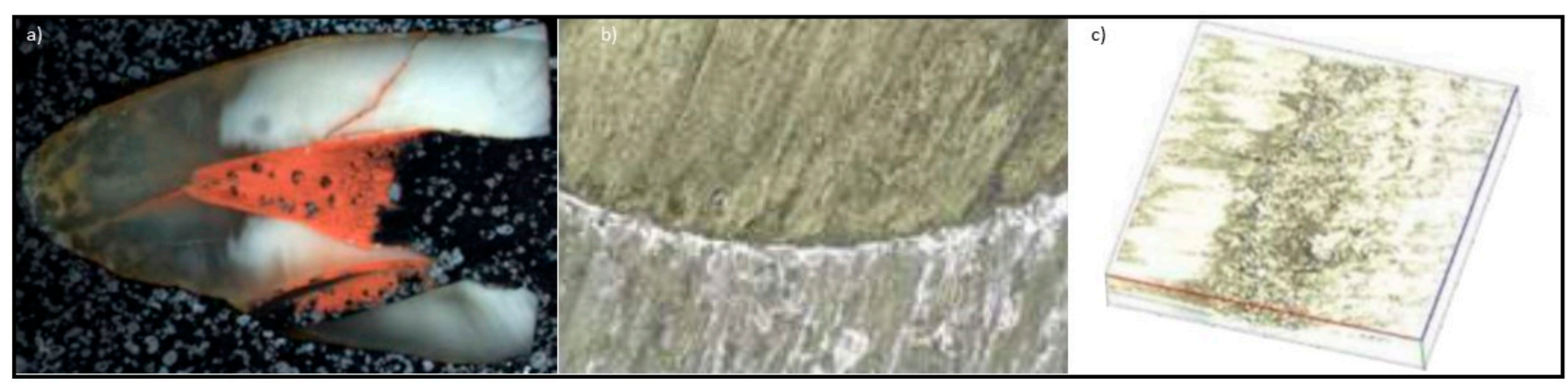

Figure 19. (a) View of the specimen made on the ISOTOM cutter and embedded in the polymer resin, viewed with LSM; (b) tight connection of the three layers of material based on gutta-percha coated with sealant and root dentin; (c) 3D visualization from (b), viewed with a laser confocal microscope (LCM).

The reason for the elimination was a very low and varied hardness of the dentin and filling parts of the tooth root, which was the reason for blurring the surface of the cut with soft structural components, especially of organic origin, as well as forcing dentin filings and substitute material into the possible gap, forcing the abrasive material used for cutting preparations and preparing materialographic specimens, even in the case of superfine diamond pastes, both in the gap and in the organic matrix and filling material, with generally much lower hardness than the abrasive, thus negating the value of the test, despite the fact that the results of tests on such preparations are found in the literature [419-425]. Based on the authors' own research, it can also be concluded that the methodology using longitudinal breakthroughs [426] without cooling the preparation in liquid nitrogen may cause chipping, or at least permanent deformation of the essentially brittle organic structural components of the preparation. Although no preparation method would show a complete lack of disadvantages, the specimens prepared as longitudinal breakthroughs after one-sided notching and breaking them immediately after cooling in liquid nitrogen and then coated by dusting with a conductive material (here: gold) were considered correct. In turn, for the observation in an automated stereoscopic microscope, the preparations obtained after decalcification without mechanically destructive procedures (Figures 8f-i and 13), and in the case of longitudinal breakthroughs without the need for sputtering, were considered satisfactory. Selected stereological methods were used to evaluate the geometrical features of the identified breakthroughs [427], commonly used in materials science. The obtained measurement results were statistically processed in a standard way, a recognized method of objectification of measurements (Figure 17), and considered satisfactory.

It has been shown that visualization methods using materialographic microscopes, especially scanning electron microscopes and mechanized light stereoscopic microscopes, due to the high resolution obtained and the possibility of unambiguous determination of the details of the tested preparation, are the most useful for assessing the effectiveness of endodontic treatment methods and techniques, after preparation of these specimens in a way that does not destroy them and does not introduce additional unrelated elements in 
the observed structure. The implementation of the methodological objectives of this work for the assessment of root canal filling tightness, as the basic criterion for the correctness of material selection and filling technique, has made a significant contribution to the methodology of in vitro dental research in the field of endodontics.

\section{Strengths, Weaknesses, Opportunities, and Threats Analysis of Filling Material Based on Gutta-Percha}

Taking into account the results of the literature studies contained in this work and the authors' previous work [70], our own experience in the field of management and heuristic sciences was used to evaluate the results of the performed experimental research. The main thesis is the statement in the title of this paper that material based on gutta-percha is still the "gold standard" among filling materials used in endodontic treatment.

For this purpose, a SWOT point analysis (strengths, weaknesses, opportunities, threats) was performed, allowing us to determine the strengths and weaknesses of the filling material based on gutta-percha and the opportunities and threats that flow for it from the environment. It is an integrated method, described, among others, in the authors' own methodological work [70], and allows confronting the key internal and external factors, both positive and negative. Thanks to this, it is possible to define a strategy of proceeding with regard to the subject of the analysis, which in the discussed case is a filling material based on gutta-percha, used for filling root canals in endodontics.

As part of the analysis, five key internal positive (strengths) and negative (weaknesses) factors were defined, and external factors also were divided into positive and negative, called opportunities and threats, respectively. In this way, a list of factors with the most important and greatest influence on developing filling material based on gutta-percha was compiled, divided into four groups, and assigned weights reflecting their importance. Each factor was then assessed using the Universal Relative State Scale, a 10-point unipolar positive interval scale with no zero, where 1 is the minimum, and 10 is the maximum possible value. The necessary information in this regard is presented in Figure 20.

Among the most important strengths of the filling material based on gutta-percha, the lack of resorption over time (S3) was distinguished, which allows the avoidance of marginal leakage at the border of the filling and the root canal wall; as well as its popularity, availability, and universality (S4), which prove the great potential of this material and indirectly indicate its good knowledge by endodontists, who will become acquainted with it during theoretical and practical training. Its strengths also include the ease of removal from the root canal in the event of revision (S2), which is crucial in the case of failures in endodontic treatment, most often resulting from improperly filled root canals or for iatrogenic reasons, such as root or crown fractures. An important strength of material based on gutta-percha is the possibility of sterilization (S1), which has gained additional importance in the time of the pandemic, and has an acceptable price (S5).

Among the most important weaknesses of gutta-percha is its mechanical strength in the root canal (W3), but this factor was rated at only 2 points, because in this respect it is second only to materials based on polymeric polyester materials and glass ionomer cements. Another weakness of gutta-percha is that the effectiveness of filling with this material, measured by the density and size of the gaps between the root canal wall and the filling, is strictly dependent on root canal preparation techniques using obturation (W5). In practice, this means that the outcome does not result from the properties of the material itself, but from the method of its application, with much better results being obtained when filled with warm material rather than cold. Other disadvantages of this material include toxicity (W1); the need to use joint sealants based on synthetic resins (W4), which complicates the obturation process; and the lack of bactericidal activity (W2), a feature provided by, for example, materials based on zinc oxide with eugenol, synthetic resins, or calcium hydroxide. 


\begin{tabular}{|c|c|c|c|c|c|c|c|c|c|}
\hline 莺 & Shrengths & 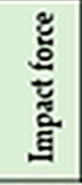 & . & 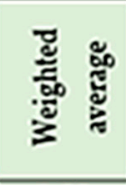 & & Wealcnesses & 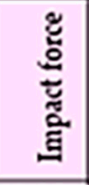 & $\stackrel{\infty}{\mathscr{J}}$ & 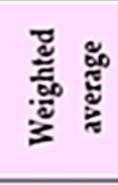 \\
\hline SII & Possibility of sterilization & 0.10 & 10 & 1.00 & WI & Toxicity & 0.20 & 3 & 0.60 \\
\hline $\mathbf{s 2}$ & $\begin{array}{c}\text { Ease of removal from the } \\
\text { root canal in the event of } \\
\text { revision }\end{array}$ & 0.20 & 10 & 2.00 & W/2 & $\begin{array}{c}\text { No bactericidal } \\
\text { activity }\end{array}$ & 0.10 & 10 & 1.00 \\
\hline 23 & No resorption over time & 0.25 & 10 & 2.50 & $W_{3}$ & $\begin{array}{l}\text { Mechanical strength } \\
\text { in the root canal }\end{array}$ & 0.30 & 2 & 0.60 \\
\hline 8 & $\begin{array}{l}\text { Popularity, availability } \\
\text { and universality }\end{array}$ & 0.25 & 8 & 2.00 & $\mathrm{Wa}$ & $\begin{array}{c}\text { Need to use sealants } \\
\text { together }\end{array}$ & 0.15 & 10 & 1.50 \\
\hline 55 & Acceptable & 0.10 & $s$ & 0.80 & W/5 & $\begin{array}{c}\text { Dependence of the } \\
\text { effectiveness of filling } \\
\text { on the techniques of } \\
\text { elaborating and } \\
\text { obturating root canals }\end{array}$ & 0.25 & 8 & 2.00 \\
\hline \multicolumn{4}{|c|}{ Numerical rating } & 8.30 & \multicolumn{4}{|c|}{ Numerical rating } & 5.70 \\
\hline 递 & Opportanities & 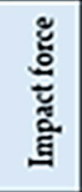 & 苞 & 胥 & & Threats & 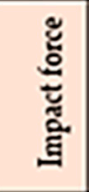 & 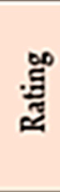 & 离 : \\
\hline OI & $\begin{array}{c}\text { Improvement of Nitinol } \\
\text { tools and techniques of } \\
\text { canal development with } \\
\text { their use }\end{array}$ & 0.15 & 8 & 1.20 & TI & $\begin{array}{c}\text { Intensive } \\
\text { development and } \\
\text { cost reduction of } \\
\text { competitive materials } \\
\text { production }\end{array}$ & 0.30 & 9 & 2.70 \\
\hline $\mathbf{O x}$ & $\begin{array}{c}\text { THC Diffusion and scale } \\
\text { effect }\end{array}$ & 0.20 & 8 & 1.60 & Tz & $\begin{array}{c}\text { Invention of a } \\
\text { completely new } \\
\text { material for } \\
\text { obturation of root } \\
\text { canals } \\
\end{array}$ & 0.15 & 8 & 1.20 \\
\hline $\mathbf{O B}$ & $\begin{array}{c}\text { Improving the properties } \\
\text { of sealants and the } \\
\text { possibility of applying } \\
\text { very thin layers }\end{array}$ & 0.10 & 7 & 0.70 & $T=$ & $\begin{array}{l}\text { Development and } \\
\text { cost reduction of cold } \\
\text { obturation methods }\end{array}$ & 0.10 & 5 & 0.50 \\
\hline OA & $\begin{array}{l}\text { Modification of the } \\
\text { composition of the } \\
\text { mixture }\end{array}$ & 0.25 & 5 & 1.25 & TA & $\begin{array}{c}\text { Considerable adverse } \\
\text { results from long- } \\
\text { term scientific } \\
\text { research }\end{array}$ & 0.25 & 3 & 0.75 \\
\hline $\mathbf{O 5}$ & $\begin{array}{l}\text { Improvement of } \\
\text { production technology } \\
\text { and reduction of } \\
\text { production costs }\end{array}$ & 0.30 & 9 & 2.70 & $T 5$ & $\begin{array}{c}\text { Promotion and } \\
\text { dissemination of } \\
\text { competitive material } \\
\text { through the industry } \\
\text { lobby } \\
\end{array}$ & 0.20 & 9 & 1.80 \\
\hline \multicolumn{4}{|c|}{ Numerical rating } & 7.45 & \multicolumn{4}{|c|}{ Numerical rating } & 0.95 \\
\hline
\end{tabular}

Figure 20. SWOT point analysis matrix (strengths, weaknesses, opportunities, threats) containing criteria and results for gutta-percha-based filling material used for root canal filling in endodontics.

Among the external positive factors, the greatest chance was improving the technology of producing filling material based on gutta-percha to reduce the production costs, and thus the price of the final product (O5). Another chance is to modify the mixture comprising gutta-percha in reducing toxicity and/or increasing bactericide while maintaining its existing advantages $(\mathrm{O} 4)$, which, however, seems relatively unlikely and is reflected in the assessment. The environmental factor that may positively affect the development of the analyzed material is also the popularization of the THC (O2) method, as it allows for the tightest fillings with material based on gutta-percha, the appearance of the scale effect, and the associated reduction of the costs of using this technology. Similarly, the 
development of filling material based on gutta-percha should be influenced by improving tools made of nitinol and the technique of mechanical preparation of root canals with their use, including curved (O1). The last chance is to improve the properties of sealants in terms of the possibility of precise application of thin layers based on synthetic resins (O3), because layers that are too thick cause their delamination, resulting in leaks.

The greatest threat from the environment was considered to be supported by the results of scientific research, intensive development, and lowering the costs of producing competing materials (T1); for example, based on polymeric polyester materials or glass ionomer cements. The image-related threat is the irrefutable research results carried out in renowned research centres, indicating improper bonding of the filling material based on gutta-percha with dentin, or a long-term harmful effect on human health (T4). The activity of the industry lobby to promote and disseminate materials competitive to gutta-percha (T5) can also be dangerous.

In the next step of the SWOT analysis, a multi-criteria analysis was performed, as a result of which four ratings were given, expressing numerical strengths (8.30) and weaknesses (5.70) of the filling material based on gutta-percha, as well as opportunities (7.45) and threats (6.95) carried by the environment (Figure 21). The strengths of the filling material based on gutta-percha quite significantly outweigh its weaknesses, while the opportunities are slightly greater than the threats. Therefore, an aggressive strategy known as MAXI-MAXI is an adequate strategy for the development of the filling material based on gutta-percha. In line with this strategy, it is advisable to diversify by searching for new geographic markets and new groups of recipients, and pursue strong expansion using the opportunities offered by the environment and constant monitoring of the identified threats.

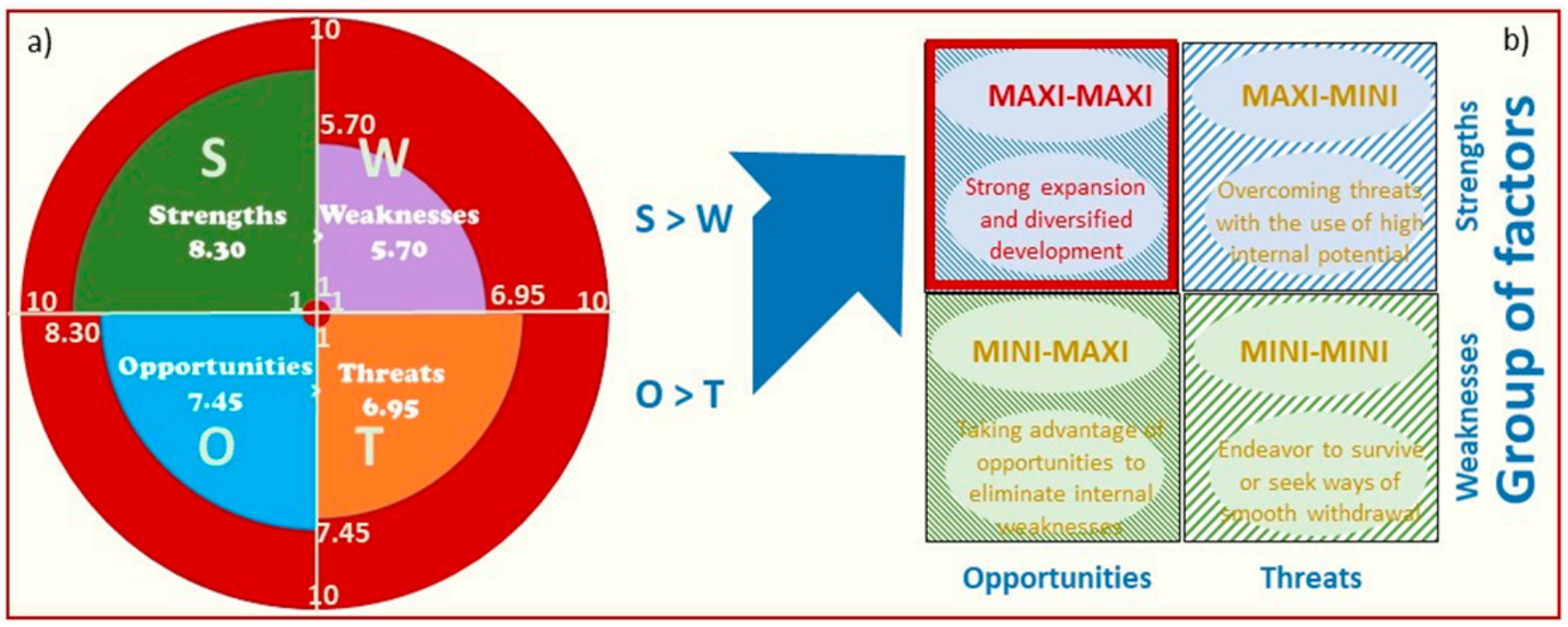

Figure 21. Scheme of the results of the SWOT analysis concerning the filling material based on gutta-percha with the numerical reflection of individual aspects of the assessment indicating the advantage of strengths and opportunities (the field area corresponds to the numerical rating of each analysis factor) (a) and their impact selection of the MAXI-MAXI strategy among four possible strategies (b).

\section{Summary and General Conclusions}

Both a very extensive analysis of the literature data and the results of experimental studies allowed for the formulation of the following conclusions regarding the filling material based on gutta-percha, among competing materials, the results of research on which are given in the authors' other works [70,428], providing, among other things, that resilon is not a dominant material over gutta-percha-based material, although its properties are also promising and very high.

The general conclusions are as follows: 
1. It has been fully confirmed that the material based on gutta-percha is still the "gold standard" among endodontic filling materials;

2. It has been shown that the cause of differentiation in the effectiveness of endodontic treatment, measured by the tightness between the root canal wall and the filling, is the formation of a tight three-layer connection between the dentin of the root canal; the sealant usually in a relatively small proportion, which is a favorable tendency; and the filling material in the form of a monoblock, ensuring a homogeneous structure; and filling with plasticized material of the lateral canals, especially using the THC method, and in the apical zone partly with a sealant, root delta with plasticized material as well as a sealant, dentinal tubules mainly with a sealant, which occurs only in the case of heat obturation with filling material based on gutta-percha using the THC method with Obtura III and System B devices, when in other cases there is no close connection of structural components, which determines the relatively lower quality of the connection and lower suitability of these methods for use in endodontics;

3. The method of root canal preparation, including the extensive use of tools made of a nickel-titanium alloy of the nitinol type, and the method of obturation, where the thermo-hydraulic condensation (THC) technique plays the most important role, while the correct selection of sealants is also of major importance;

4. The best efficiency of root canal filling among the analyzed and empirically tested in this study was ensured by the technology consisting of the preparation of dental canals with K3 rotary tools and filling the teeth with the THC thermoplastic method using System B and Obtura III devices with studs and pellets made of material based on gutta-percha after covering the walls root canal with a thin layer of $\mathrm{AH}$ Plus sealant;

5. It has been shown that visualization methods with the use of materialographic microscopes, especially the scanning electron microscope (SEM) and the light stereoscopic microscope (LSM), due to the possibility of obtaining a sufficiently high resolution with which to observe the tested specimens, and the possibility of unequivocally determining the details of the tested material, are most useful for evaluation of the effectiveness of methods and techniques of endodontic treatment in vitro and ex post, where it is recommended to make preparations by breaking them after cooling them in liquid nitrogen along the tooth axis, because the use of specimens prepared differently is much lower, especially as materialographic samples.

Author Contributions: Conceptualization, literature review, presentation, design, resources, data curation, software, formal analysis, writing, original draft preparation, visualization, J.D., L.B.D., L.A.D., and A.D.D.-D.; practical verification, J.D., L.B.D., and K.G., writing-review and editing, L.A.D., L.B.D., J.D., and A.D.D.-D., supervision, project administration, funding acquisition, L.A.D., L.B.D., and J.D. All authors have read and agreed to the published version of the manuscript.

Funding: This research was not directly financed by external funding.

Conflicts of Interest: The authors declare no conflict of interest.

Notice: The paper was prepared due actually implement Project POIR.01.01-00-0485/16-00 on "IMSKA-MAT Innovative dental and maxillofacial implants manufactured using the innovative additive technology supported by computer-aided materials design ADD-MAT" realized by the Medical and Dental Engineering Center for Research, Design, and Production ASKLEPIOS in Gliwice, Poland. The project was implemented in 2017-2021 and was co-financed by the Operational Program Intelligent Development of the European Union.

\section{References}

1. Dobrzański, L.A.; Dobrzański, L.B.; Dobrzańska-Danikiewicz, A.D.; Dobrzańska, J. The Concept of Sustainable Development of Modern Dentistry. Processes 2020, 8, 1605. [CrossRef]

2. Caldas, A.F., Jr. Reason for tooth extraction in a Brazilian population. Int. Dent. J. 2000, 50, 267-273. [CrossRef]

3. Chestnutt, I.G.; Binnie, V.I.; Taylor, M.M. Reason for tooth extraction in Scotland. J. Dent. 2000, 28, 295-297. [CrossRef] 
4. Morita, M.; Kimura, T.; Kanegae, M.; Ishikawa, A.; Watanobe, T. Reasons for extraction of permanent teeth in Japan. Community Dent. Oral. Epidemiol. 1994, 22, 303-306. [CrossRef] [PubMed]

5. Angelillo, I.F.; Nobile, C.G.A.; Pavia, M. Survey of reasons for extraction of permanent teeth in Italy. Community Dent. Oral. Epidemiol. 1996, 24, 336-340. [CrossRef] [PubMed]

6. Al-Shammari, K.F.; Al-Arsari, J.M.; Al-Melh, M.A.; Al-Khabhaz, A.K. Reasons for tooth extraction in Kuwait. Med. Princ. Pract. 2006, 15, 417-422. [CrossRef]

7. Fejerskov, O. Concepts of dental caries and their consequences for understanding the disease. Community Dent. Oral Epidemiol. 1997, 25, 5-12. [CrossRef] [PubMed]

8. Reisine, S.; Litt, M. Social and psychological theories and their use for dental practice. Int. Dent. J. 1993, 43, $279-287$.

9. Selwitz, R.H.; Ismail, A.I.; Pitts, N.B. Dental caries. Lancet 2007, 369, 51-59. [CrossRef]

10. Costerton, J.W. Introduction to biofilm. Int. J. Antimicrob. Agents 1999, 11, 217-221. [CrossRef]

11. Svensater, G.; Bergenholtz, G. Biofilms in endodontic infections. Endod. Top. 2004, 9, 27-36. [CrossRef]

12. Zero, D.T. Dental caries process. Dent. Clin. N. Am. 1999, 43, 635-664.

13. Featherstone, J.D. The continuum of dental caries-evidence for a dynamic disease process. J. Dent. Res. 2004, 83, C39-C42. [CrossRef] [PubMed]

14. Pitts, N.B. A review of the current knowledge of the progress of approximal lesions. In Proceedings of the 10th Asian Pacific Dental Scientific Congress, Singapore, 26-31 March 1981; Singapore Dental Association: Singapore, 1983; pp. 31-36.

15. Amaechi, B.T. Remineralization therapies for initial caries lesions. Curr. Oral Health Rep. 2015, 2, 95-101. [CrossRef]

16. Zero, D.T. Dentifrices, mouthwashes, and remineralization/caries arrestment strategies. BMC Oral Health 2006, 6, S9. [CrossRef] [PubMed]

17. Holmgren, C.; Gaucher, N.; Decerle, N.; Doméjean, S. Minimal intervention dentistry II: Part 3. Management of non-cavitated (initial) occlusal caries lesions-Non-invasive approaches through remineralization and therapeutic sealants. Br. Dent. J. 2014, 216, 237-243. [CrossRef]

18. Takahashi, N.; Nyvad, B. Caries ecology revisited: Microbial dynamics and the caries process. Caries Res. 2008, 42, 409-418. [CrossRef]

19. Margolis, H.C.; Moreno, E.C. Composition and cariogenic potential of dental plaque fluid. Crit. Rev. Oral Biol. Med. 1994, 5, 1-25. [CrossRef]

20. Margolis, H.C.; Moreno, E.C. Kinetics of hydroxyapatite dissolution in acetic, lactic, and phosphoric acid solutions. Calcif. Tissue Int. 1992, 50, 137-143. [CrossRef]

21. Vogel, G.L.; Carey, C.M.; Chow, L.C.; Gregory, T.M.; Brown, W.E. Micro-analysis of mineral saturation within enamel during lactic acid demineralization. J. Dent. Res. 1988, 67, 1172-1180. [CrossRef]

22. Reynolds, E.C.; Cai, F.; Shen, P.; Walker, G.D. Retention in plaque and remineralization of enamel lesions by various forms of calcium in a mouthrinse or sugar-free chewing gum. J. Dent. Res. 2003, 82, 206-211. [CrossRef]

23. Kitasako, Y.; Sadr, A.; Hamba, H.; Ikeda, M.; Tagami, J. Gum containing calcium fluoride reinforces enamel subsurface lesions in situ. J. Dent. Res. 2012, 91, 370-375. [CrossRef] [PubMed]

24. Hamba, H.; Nikaido, T.; Inoue, G.; Sadr, A.; Tagami, J. Effects of CPP-ACP with sodium fluoride on inhibition of bovine enamel demineralization: A quantitative assessment using micro-computed tomography. J. Dent. 2011, 39, 405-413. [CrossRef]

25. ten Cate, J.M.; Featherstone, J.D. Mechanistic aspects of the interactions between fluoride and dental enamel. Crit. Rev. Oral Biol. Med. 1991, 2, 283-296. [CrossRef] [PubMed]

26. Lee, Y.E.; Baek, H.J.; Choi, Y.H.; Jeong, S.H.; Park, Y.D.; Song, K.B. Comparison of remineralization effect of three topical fluoride regimens on enamel initial carious lesions. J. Dent. 2010, 38, 166-171. [CrossRef] [PubMed]

27. Amaechi, B.T; van Loveren, C. Fluorides and non-fluoride remineralization systems. Monogr. Oral Sci. 2013, 23, 15-26. [CrossRef]

28. Featherstone, J.D. Prevention and reversal of dental caries: Role of low level fluoride. Community Dent. Oral Epidemiol. 1999, 27, 31-40. [CrossRef]

29. Iheozor-Ejiofor, Z.; Worthington, H.V.; Walsh, T.; O’Malley, L.; Clarkson, J.E.; Macey, R.; Alam, R.; Tugwell, P.; Welch, V.; Glenny, AM. Water fluoridation for the prevention of dental caries. Cochrane Database Syst. Rev. 2015, 6, CD010856. [CrossRef]

30. Pitts, N.B.; Zero, D.T.; White Paper on Dental Caries Prevention and Management. FDI World Dental Federation. Available online: https:/ / www.fdiworlddental.org/sites/default/files/2020-11/2016-fdi_cpp-white_paper.pdf (accessed on 19 May 2021).

31. Kidd, E.A.M.; Fejerskov, O. What constitutes dental caries? Histopathology of carious enamel and dentin related to the action of cariogenic biofilms. J. Dent. Res. 2004, 83, C35-C38. [CrossRef] [PubMed]

32. Yu, C.; Abbott, P.V. An overview of the dental pulp: Its functions and responses to injury. Aust. Dent. J. 2007, 52, S4-S16. [CrossRef]

33. Harumi Miyagi, S.P.; Kerkis, I.; da Costa Maranduba, C.M.; Gomes, C.M.; Martinis, M.D.; Marques, M.M. Expression of extracellular matrix proteins in human dental pulp stem cells depends on the donor tooth conditions. J. Endod. 2010, 36, 826-831. [CrossRef] [PubMed]

34. Dobrzańska, J. Analiza Szczelności Wypełnień Kanałów Korzeniowych. Ph.D. Thesis, Śląski Uniwersytet Medyczny w Katowicach, Zabrze, Poland, 2011.

35. Seltzer, S.; Farber, P.A. Microbiologic factors in endodontology. Oral Surg. Oral Med. Oral Pathol. 1994, 78, 634-645. [CrossRef] 
36. Aas, J.A.; Griffen, A.L.; Dardis, S.R.; Lee, A.M.; Olsen, I.; Dewhirst, F.E.; Leys, E.J.; Paster, B.J. Bacteria of dental caries in primary and permanent teeth in children and young adults. J. Clin. Microbiol. 2008, 46, 1407-1417. [CrossRef] [PubMed]

37. Spratt, D.A.; Pratten, J.; Wilson, M.; Gulabivala, K. An in vitro evaluation of the antimicrobial efficacy of irrigants on biofilms of root canal isolates. Int. Endod. J. 2001, 34, 300-307. [CrossRef]

38. Vieira, C.L.Z.; Caramelli, B. The history of dentistry and medicine relationship: Could the mounth finally return to the body? Oral Dis. 2009, 15, 538-546. [CrossRef]

39. Paju, S.; Scannapieco, F.A. Oral biofilms, periodontitis and pulmonary infections. Oral Dis. 2007, 13, 508-512. [CrossRef] [PubMed]

40. Al-Nawas, B.; Maeurer, M. Severe versus local odontogenic bacterial infections: Comparision of microbial isolates. Eur. Surg. Res. 2008, 40, 220-224. [CrossRef]

41. Stanley, H.R. Dental iatrogenesis. Int. Dent. J. 1994, 44, 3-18. [PubMed]

42. Love, R.M. Effects of dental trauma on the pulp. Pract. Periodontics Aesthert. Dent. 1997, 9, 427-436.

43. Mueller, A.A.; Saldami, B.; Stübinger, S.; Walter, C.; Flückiger, U.; Merlo, A.; Schwenzer-Zimmerer, K.; Zeilhofer, H.F.; Zimmerer, S. Oral bacterial cultures in nontraumatic brain abscesses: Results of a first line study. Oral Surg. Oral Med. Oral Pathol. Oral Radiol. Endod. 2009, 107, 469-476. [CrossRef]

44. Pallasch, T.J.; Wahl, M.J. Focal infection: New age or ancient history? Endod. Top. 2003, 4, 32-45. [CrossRef]

45. Buset, S.L.; Walter, C.; Friedmann, A.; Weiger, R.; Borgnakke, W.S.; Zitzmann, N.U. Are periodontal diseases really silent? A systematic review of their effect on quality of life. J. Clin. Periodontol. 2016, 43, 333-344. [CrossRef] [PubMed]

46. Sierpinska, T.; Golebiewska, M.; Dlugosz, J.W.; Kemona, A.; Laszewicz, W. Connection between masticatory efficiency and pathomorphologic changes in gastric mucosa. Quintessence Int. 2007, 38, 31-37.

47. De Pablo, P.; Dietrich, T.; McAlindon, T.E. Association of periodontal disease and tooth loss with rheumatoid arthritis in the US population. J. Rheumatol. 2008, 35, 70-76.

48. Felton, D.A. Edentualism and comorbid factors. J. Prosthodont. 2009, 18, 88-96. [CrossRef]

49. Volzke, H.; Schwahn, C.; Hummel, A.; Wolff, B.; Kleine, V.; Robinson, D.M.; Dahm, J.B.; Felix, S.B.; John, U.; Kocher, T. Tooth loss is independently associated with the risk of acquired aortic valve sclerosis. Am. Heart J. 2005, 150, 1198-1203. [CrossRef]

50. Bagchi, S.; Tripathi, A.; Tripathi, S.; Kar, S.; Tiwari, S.C.; Singh, J. Obstructive sleep apnea and neurocognitive dysfunction in edentulous patients. J. Prosthodont. 2019, 28, e837-e842. [CrossRef] [PubMed]

51. Nagpal, R.; Yamashiro, Y.; Izumi, Y. The two-way association of periodontal infection with systemic disorders: An overview. Mediat. Inflamm. 2015, 2015, 793898. [CrossRef] [PubMed]

52. Abnet, C.C.; Qiao, Y.L.; Dawsey, S.M.; Dong, Z.W.; Taylor, P.R.; Mark, S.D. Tooth loss is associated with increased risk of total death and death from upper gastrointestinal cancer, heart disease, and stroke in a Chinese population-based cohort. Int. J. Epidemiol. 2005, 34, 467-474. [CrossRef] [PubMed]

53. Burzyńska, B.; Mierzwińska-Nastalska, E. Rehabilitacja protetyczna pacjentów bezzębnych. Nowa Stomatol. 2011, 4, 167-199.

54. Bui, F.Q.; Almeida-da-Silva, C.L.C.; Huynh, B.; Trinh, A.; Liu, J.; Woodward, J.; Asadi, H.; Ojcius, D.M. Association between periodontal pathogens and systemic disease. Biomed. J. 2019, 42, 27-35. [CrossRef] [PubMed]

55. Holmlund, A.; Holm, G.; Lind, L. Number of teeth as a predictor of cardiovascular mortality in a cohort of 7674 subjects followed for 12 years. J. Periodontol. 2010, 81, 870-876. [CrossRef]

56. Takata, Y.; Ansai, T.; Matsumura, K.; Awano, S.; Hamasaki, T.; Sonoki, K.; Kusaba, A.; Akifusa, S.; Takehara, T. Relationship between tooth loss and electrocardiographic abnormalities in octogenarians. J. Dent. Res. 2001, 80, 1648-1652. [CrossRef]

57. Felton, D.A. Complete edentulism and comorbid diseases: An update. J. Prosthodont. 2016, 25, 5-20. [CrossRef] [PubMed]

58. Chen, H.; Iinuma, M.; Onozuka, M.; Kubo, K.-Y. Chewing maintains hippocampus-dependent cognitive. Int. J. Med. Sci. 2015, 12, 502-509. [CrossRef]

59. Stein, P.S.; Desrosiers, M.; Donegan, S.J.; Yepes, J.F.; Kryscio, R.J. Tooth loss, dementia and neuropathology in the Nun study. J. Am. Dent. Assoc. 2007, 138, 1314-1322. [CrossRef] [PubMed]

60. Henke, K. A model for memory systems based on processing modes rather than consciousness. Nat. Rev. Neurosci. 2010, 11, 523-532. [CrossRef] [PubMed]

61. Lexomboon, D.; Trulsson, M.; Wårdh, I.; Parker, W.G. Chewing ability and tooth loss: Association with cognitive impairment in an elderly population study. J. Am. Geriatr. Soc. 2012, 60, 1951-1956. [CrossRef]

62. Hirano, Y.; Obata, T.; Takahashi, H.; Tachibana, A.; Kuroiwa, D.; Takahashi, T.; Ikehira, H.; Onozuka, M. Effects of chewing on cognitive processing speed. Brain Cognit. 2013, 81, 376-381. [CrossRef]

63. Onishi, M.; Iinuma, M.; Tamura, Y.; Kubo, K.Y. Learning deficits and suppression of the cell proliferation in the hippocampal dentate gyrus of offspring are attenuated by maternal chewing during prenatal stress. Neurosci. Lett. 2014, 560, 77-80. [CrossRef]

64. Kawahata, M.; Ono, Y.; Ohno, A.; Kawamoto, S.; Kimoto, K.; Onozuka, M. Loss of molars early in life develops behavioral lateralization and impairs hippocampus-dependent recognition memory. BMC Neurosci. 2014, 15, 4. [CrossRef] [PubMed]

65. Li, X.; Tornstad, L.; Olsen, I. Brain abscesses caused by oral infection. Dent. Traumatol. 1999, 15, 95-101. [CrossRef] [PubMed]

66. Scannapieco, F.A.; Bush, R.B.; Paju, S. Associations between periodontal disease and risk for nosocomial bacterial pneumonia and chronic obstructive pulmonary disease. A systemic review. Ann. Periodontol. 2003, 8, 54-69. [CrossRef] [PubMed] 
67. Dobrzański, L.A.; Dobrzański, L.B.; Dobrzańska-Danikiewicz, A.D.; Dobrzańska, J.; Rudziarczyk, K.; Achtelik-Franczak, A. Non-antagonistic contradictoriness of the progress of advanced digitized production with SARS-CoV-2 virus transmission in the area of dental engineering. Processes 2020, 8, 1097. [CrossRef]

68. Aleksander, M.; Krishnan, B.; Shenoy, N. Diabetes mellitus and odontogenic infections-an exaggerated risk? Oral Maxillofac. Surg. 2008, 12, 129-130. [CrossRef] [PubMed]

69. Scannapieco, F.A. Role of oral bacteria in respiratory infection. J. Periodontol. 1999, 70, 793-802. [CrossRef]

70. Dobrzańska, J.; Dobrzański, L.B.; Gołombek, K.; Dobrzański, L.A.; Dobrzańska-Danikiewicz, A.D. Virtual approach to the comparative analysis of biomaterials used in endodontic treatment. Processes 2021, 9, 926. [CrossRef]

71. Castellucci, A. Endodontics Vol. 1; Il Tridente Edizioni Odontolatriche: Bologna, Italy, 2005.

72. Alwadani, M.; Mashyakhy, M.H.; Jali, A.; Hakami, A.O.; Areshi, A.; Daghriri, A.A.; Shaabi, F.I.; Al Moaleem, M.M. Dentists and Dental Intern's Preferences of Root Canal Treatment with Restoration Versus Extraction then Implant-Supported Crown Treatment Plan. Open Dent. J. 2019, 13, 93-100. [CrossRef]

73. Estrela, C.; Holland, R.; Estrela, C.R.; Alencar, A.H.; Sousa-Neto, M.D.; Pécora, J.D. Characterization of successful root canal treatment. Braz. Dent. J. 2014, 25, 3-11. [CrossRef]

74. Marthaler, T.M. A standardized system of recording dental conditions. Helv. Odontol. Acta 1966, 10, 1-18.

75. Dirks, O.B.; van Amerongen, J.; Winkler, K.C. A reproducible method for caries evaluation. J. Dent. Res. 1951, 30, 346-359. [CrossRef]

76. Black, G.V. A Work on Operative Dentistry: The Technical Procedures in Filling Teeth; Medico-Dental Publishing: Chicago, IL, USA, 1917; p. 5.

77. Pitts, N. "ICDAS"-An international system for caries detection and assessment being developed to facilitate caries epidemiology, research and appropriate clinical management. Community Dent. Health 2004, 21, 193-198. [PubMed]

78. ICDAS Website. Available online: https://www.icdas.org/ (accessed on 6 April 2021).

79. Ismail, A.I.; Sohn, W.; Tellez, M.; Amaya, A.; Sen, A.; Hasson, H.; Pitts, N.B. The International Caries Detection and Assessment System (ICDAS): An integrated system for measuring dental caries. Community Dent. Oral Epidemiol. 2007, 35, 170-178. [CrossRef]

80. Ismail, A.; Tellez, M.; Pitts, N.B.; Ekstrand, K.R.; Ricketts, D.; Longbottom, C.; Eggertsson, H.; Deery, C.; Fisher, J.; Young, D.A.; et al. Caries management pathways preserve dental tissues and promote oral health. Community Dent. Oral Epidemiol. 2013, 41, e12-e40. [CrossRef]

81. Pitts, N.B.; Ekstrand, K.R. International Caries Detection and Assessment System (ICDAS) and its International Caries Classification and Management System (ICCMS) - Methods for staging of the caries process and enabling dentists to manage caries. Community Dent. Oral Epidemiol. 2013, 41, e41-e52. [CrossRef]

82. Ormond, C.; Douglas, G.; Pitts, N. The use of the International Caries Detection and Assessment System (ICDAS) in a National Health Service general dental practice as part of an oral health assessment. Prim. Dent. Care 2010, 17, 153-159. [CrossRef]

83. Ismail, A.; Pitts, N.B.; Tellez, M. The international caries classification and management system (ICCMS ${ }^{\mathrm{TM}}$ ) an example of a caries management pathway. BMC Oral Health 2015, 15, S9. [CrossRef] [PubMed]

84. Clarkson, B.H.; Exterkate, R.A.M. Noninvasive dentistry: A dream or reality? Caries Res. 2015, 49 (Suppl. 1), 11-17. [CrossRef] [PubMed]

85. Wierichs, R.J.; Meyer-Lueckel, H. Systematic review on noninvasive treatment of root caries lesions. J. Dent. Res. 2015, 94, 261-271. [CrossRef] [PubMed]

86. Marsh, P.D.; Head, D.A.; Devine, D.A. Prospects of oral disease control in the future-An opinion. J. Oral Microbiol. 2014, 6, 261-276. [CrossRef]

87. Edwards Deming, W. Out of the Crisis; Massachusetts Institute of Technology, Center for Advanced Engineering Study: Cambridge, MA, USA, 1986.

88. Cohen, S.; Hargreaves, K. Pathways of the Pulp, 9th ed.; Mosby: St. Louis, MO, USA, 2006.

89. Krasner, P.; Rankow, H.J.; Abrams, E.S. Endodontics. Colleagues for Excellence. Access Opening and Canal Location; American Association of Endodontists: Chicago, IL, USA, 2010.

90. Krasner, P.; Rankow, H.J. Anatomy of the pulp-chamber floor. J. Endod. 2004, 30, 5-16. [CrossRef]

91. Moreinis, S.A. Avoiding perforation during endodontic access. J. Am. Dent. Assoc. 1979, 98, 707-712. [CrossRef]

92. Weller, R.N.; Hartwell, G.R. The impact of improved access and searching techniques on detection of the mesiolingual canal in maxillary molars. J. Endod. 1989, 15, 82-83. [CrossRef]

93. Dental Consumables Market by Product [Dental Implants (Root Form Dental Implants and Plate Form Dental Implants), Dental Prosthetics (Crowns, Bridges, Dentures, Abutments, Veneers, and Inlays \& Onlays), Endodontics (Endodontic Files, Obturators, and Permanent Endodontic Sealers), Orthodontics (Brackets, Archwires, Anchorage Appliances, and Ligatures), Periodontics (Dental Sutures and Dental Hemostats), Retail Dental Care Essentials (Specialized Dental Pastes, Dental Brushes, Dental Wash Solutions, Whitening Agents, and Dental Floss), and Other Dental Consumables (Dental Splints, Dental Sealants, Dental Burs, Dental Impression Materials, Dental Disposables, Bonding Agents, Patient Bibs, and Aspirator Tubes \& Saliva Ejectors)]—Global Opportunity Analysis and Industry Forecast, 2017-2023. Available online: https://www.alliedmarketresearch.com/dentalconsumables-market (accessed on 7 May 2021). 
94. Endodontic Devices Market Size, Share \& Trends Analysis Report by Type (Instruments, Consumables), by End Use (Hospitals, Clinics, Dental Academic \& Research Institutes), And Segment Forecasts, 2019-2026. Available online: https://www. grandviewresearch.com/industry-analysis/endodontic-devices-market (accessed on 7 May 2021).

95. Dental Endodontics Market (Product-Instruments (Endodontic Scalers \& Lasers, Motors, Apex Locators, and Machine Assisted Obturation Systems) and Consumables (Obturation, Shaping and Cleaning, and Access Cavity Preparation); End User: Dental Hospitals, Dental Clinics, and Dental Academic \& Research Institutes)—Global Industry Analysis, Size, Share, Growth, Trends, and Forecast 2017-2025. Available online: https:/ / www.transparencymarketresearch.com/dental-endodontics-market.html (accessed on 7 May 2021).

96. Wang, Z.; Pan, J.; Wright, J.T.; Bencharit, S.; Zhang, S.; Everett, E.T.; Teixeira, F.B.; Preisser, J.S. Putative stem cells in human dental pulp with irreversible pulpitis: An exploratory study. J. Endod. 2010, 36, 820-825. [CrossRef] [PubMed]

97. Krupiński, J. Endodoncja Praktyczna; Wyd. Kwintesencja: Warszawa, Poland, 2008; pp. 30-44.

98. Siqueira, J.F.; Rocas, I.N.; Lopes, H.P.; de Uzeda, M. Coronal leakage of two root canal sealers containing calcium hydroxide after exposure to human saliva. J. Endod. 1999, 25, 14-16. [CrossRef]

99. Hirsch, J.M.; Ahlstrom, U.; Henrikson, P.A.; Peterson, LE. Periapical surgery. Int. J. Oral Surg. 1979, 8, 173-185. [CrossRef]

100. Sundqvist, G.; Figdor, D.; Persson, S.; Sjörgren, U. Microbiological analysis of teeth with failed endodontic treatment and the outcome of conservative re-treatment. Oral Surg. Oral Med. Oral Pathol. Oral Radiol. Endod. 1998, 85, 86-93. [CrossRef]

101. Carrotte, P. Endodontics: Part 1. The modern concept of root canal treatment. Br. Dent. J. 2004, 197, 181-183. [CrossRef]

102. Stabholz, A.; Sahar-Helft, S.; Moshonov, J. Lasers in endodontics. Dent. Clin. N. Am. 2004, 48, 809-832. [CrossRef]

103. Kimura, Y.; Wilder-Smith, P.; Matsumoto, K. Lasers in endodontics: A review. Int. Endod. J. 2000, 33, 173-185. [CrossRef]

104. Van der Sluis, L.W.M.; Versluis, M.; Wu, M.K.; Wasserlink, P.R. Passive ultrasonic irrigation of the root canal: A review of the literature. Int. Endod. J. 2007, 40, 415-426. [CrossRef]

105. Roy, R.A.; Ahmad, M.; Crum, L.A. Physical mechanisms governing the hydrodynamic response of an oscillating ultrasonic file. Int. Endod. J. 1994, 27, 197-207. [CrossRef] [PubMed]

106. Huque, J.; Kota, K.; Yamaga, M.; Iwaku, M.; Hoshino, E. Bacterial eradication from root dentine by ultrasonic irrigation with sodium hypochloride. Int. Endod. J. 1998, 31, 242-250. [CrossRef]

107. Asgary, S.; Shadman, B.; Ghalamkarpour, Z.; Shahravan, A.; Ghoddusi, J.; Bagherpour, A.; Akbarzadeh Baghban, A.; Hashemipour, M.; Ghasemian Pour, M. Periapical status and quality of root canal filling and coronal restoration in Iranian population. Iran. Endod. J. 2010, 5, 74-82.

108. Ǿstravik, D. Materials used for root canal obturation: Technical, biological and clinical testing. Endod. Top. 2005, 12, 25-38. [CrossRef]

109. Teoh, Y.-Y.; Walsh, L.J. Residual Endodontic Filling Material after Post Space Preparation: A Confocal Microscopic Study. Materials 2017, 10, 1333. [CrossRef] [PubMed]

110. Ferreira, C.M.; Silva, J.B.A., Jr.; de Paula, R.C.M.; Andrade Feitosa, J.P.; Negreiros Cortez, D.G.; Zaia, A.A.; de Souza-Filho, F.J. Brazilian gutta-percha points. Part I: Chemical composition and X-ray diffraction analysis. Braz. Oral Res. 2005, 19, 193-197. [CrossRef] [PubMed]

111. Dobrzańska, J.; Gołombek, K.; Dobrzański, L.B. Polymer materials used in endodontic treatment-in vitro testing. AMSE 2012, $58,110-115$.

112. Chauhan, A.; Makkar, S.; Garg, N.; Khade, A.; Bhagat, S.; Agarwal, R. Comparison of the apical sealing ability of gutta-percha by three different obturation techniques: Lateral Condensation technique, Single cone root canal obturation technique and Injectable thermoplasticized gutta-percha technique (System B). Ann. RSCB 2021, 25, 873-879.

113. Schilder, H.; Goodman, A.; Winthrop, A. The termomechanical properties of gutta-percha. Determination of phase transition temperatures for gutta-percha. Oral Surg. Oral Med. Oral Pathol. 1974, 38, 109-114. [CrossRef]

114. Ferreira, C.M.; Gurgel-Filho, E.D.; Silva, J.B.A., Jr.; de Paula, R.C.M.; Pessoa Andrade Feitosa, J.; de Almeida Gomes, B.P.F.; de Souza-Filho, F.J. Brazilian gutta-percha points. Part II: Thermal properties. Braz. Oral Res. 2007, 21, 29-34. [CrossRef] [PubMed]

115. Combe, E.C.; Cohen, B.D.; Cumming, K. Alpha- and beta-forms of gutta-percha in products for root canal filling. Int. Endodon. J. 2001, 34, 447-451. [CrossRef]

116. Ribeiro, M.A.; Queiroz, A.C.F.S.; Silva, P.G.; Yoshinari, G.H.; Guerisoli, D.M.Z.; Pereira, K.F.S. Comparative study of the area filled with gutta-percha in the TC, Thermafil and Lateral Condensation techniques. Rev. Odontol. UNESP 2009, 38, 65-71.

117. Li, G.H.; Niu, L.N.; Selem, L.C.; Eid, A.A.; Bergeron, B.E.; Chen, J.H.; Pashley, D.H.; Tay, F.R. Quality of obturation achieved by an endodontic core-carrier system with crosslinked gutta-percha carrier in single-rooted canals. J. Dent. 2014, 42, 1124-1134. [CrossRef] [PubMed]

118. Shin, S.J.; Jee, S.W.; Song, J.S.; Jung, I.Y.; Cha, J.H.; Kim, E. Comparison of regrowth of Enterococcus faecalis in dentinal tubules after sealing with gutta-percha or Resilon. J. Endod. 2008, 34, 445-448. [CrossRef]

119. Jack, R.M.; Goodell, G.G. In vitro comparison of coronal microleakage between Resilon alone and gutta-percha with a glass ionomer intraorifice barrier using a fluid filtration model. J. Endod. 2008, 34, 718-720. [CrossRef]

120. Santos, J.; Tjäderhane, L.; Ferraz, C.; Zaia, A.; Alves, M.; De Goes, M.; Carrilho, M. Long-term sealing ability of resin-based root canal fillings. Int. Endod. J. 2010, 43, 455-460. [CrossRef]

121. Shemesh, H.; Wu, M.K.; Wesselink, P.R. Leakage along the apical root fillings with and without smear layer using two different leakage models: A two month longitudinal ex vivo study. Int. Endod. J. 2006, 39, 968-976. [CrossRef] 
122. De Bruyne, M.A.; De Moor, R.J. Long-term sealing ability of Resilon apical root-end fillings. Int. Endod. J. 2009, 42, 884-892. [CrossRef]

123. Deus, G.A.D.; Fábio, M.; Rocha, L.A.C.M.; Gurgel-Filho, E.D.; Maniglia, C.F.; Coutinho-Filho, T. Analysis of the film thickness of a root canal sealer following three obturation techniques. Pesqui Odontol. Bras. 2003, 17, 119-125. [CrossRef]

124. Paqué, F.; Sirtes, G. Apical sealing ability of Resilon/Epiphany versus gutta-percha/AH Plus: Immediate and 16 month leakage. Int. Endod. J. 2007, 40, 722-729. [CrossRef]

125. Pasqualini, D.; Scotti, N.; Mollo, L.; Berutti, E.; Angelini, E.; Migliaretti, G.; Cuffini, A.; Adlerstein, D. Microbial leakage of Gutta-Percha and Resilon root canal filling material: A comparative study using a new homogeneous assay for sequence detection. J. Biomater. Appl. 2008, 22, 337-352. [CrossRef] [PubMed]

126. Shemesh, H.; Souza, E.M.; Wu, M.K.; Wesselink, P.R. Glucose reactivity with filling materials as a limitation for using the glucose leakage model. Int. Endod. J. 2008, 41, 869-872. [CrossRef]

127. Kokorikos, I.; Kolokouris, I.; Economides, N.; Gogos, C.; Helvatjoglu-Antoniades, M. Long-term evaluation of the sealing ability of two root canal sealers in combination with self-etching bonding agents. J. Adhes. Dent. 2009, 11, 239-246. [PubMed]

128. Onay, E.O.; Ungor, M.; Orucoglu, H. An in vitro evaluation of the apical sealing ability of a new resin based root canal obturation system. J. Endod. 2006, 32, 976-978. [CrossRef] [PubMed]

129. Hirai, V.H.; da Silva Neto, U.X.; Westphalen, V.P.D.; Perin, C.P.; Carneiro, E.; Fariniuk, L.F. Comparative analysis of leakage in root canal filling performed with gutta-percha and Resilon cones with AH Plus and Epiphany sealers. Oral Surg. Oral Med. Oral Pathol. Oral Radiol. Endod. 2010, 109, 131-135. [CrossRef] [PubMed]

130. Saleh, I.M.; Ruyter, I.E.; Haapasalo, M.; Ørstavik, D. Bacterial penetration along different root canal filling materials in the presence or absence of smear layer. Int. Endod. J. 2008, 41, 32-40. [CrossRef] [PubMed]

131. De-Deus, G.; Namen, F.; Galan, J. Reduced long-term sealing ability of adhesive root fillings after water-storage stress. J. Endod. 2008, 34, 322-325. [CrossRef] [PubMed]

132. Pandey, P.; Aggarwal, H.; Tikku, A.P.; Singh, A.; Bains, R.; Mishra, S. Comparative evaluation of sealing ability of gutta percha and resilon as root canal filling materials- a systematic review. J. Oral Biol. Craniofac. Res. 2020, 10, 220-226. [CrossRef] [PubMed]

133. Barborka, B.J.; Woodmansey, K.F.; Glickman, G.N.; Schneiderman, E.; He, J. Long-term Clinical Outcome of Teeth Obturated with Resilon. J. Endod. 2017, 43, 556-560. [CrossRef]

134. Teixeira, F.B.; Teixeira, E.C.; Thompson, J.Y.; Trope, M. Fracture resistance of roots endodontically treated with a new resin filling material. J. Am. Dent. Assoc. 2004, 135, 646-652. [CrossRef]

135. Donnermeyer, D.; Bürklein, S.; Dammaschke, T.; Schäfer, E. Endodontic sealers based on calcium silicates: A systematic review. Odontol. 2019, 107, 421-436. [CrossRef] [PubMed]

136. Gandolfi, M.G.; Siboni, F.; Prati, C. Properties of a novel polysiloxane-guttapercha calcium silicate-bioglass-containing root canal sealer. Dent. Mater. 2016, 32, e113-e126. [CrossRef]

137. Zoufan, K.; Jiang, J.; Komabayashi, T.; Wang, Y.-H.; Safavi, K.E.; Zhu, Q. Cytotoxicity evaluation of Gutta Flow and Endo Sequence BC sealers. Oral Surg. Oral Med. Oral Pathol. Oral Radiol. Endod. 2011, 112, 657-661. [CrossRef] [PubMed]

138. Shipper, G.; Ørstavik, D.; Teixeira, F.B.; Trope, M. An evaluation of microbial leakage in roots filled with a thermoplastic synthetic polymer-based root canal filling material (Resilon). J. Endod. 2004, 30, 342-347. [CrossRef] [PubMed]

139. Shipper, G.; Teixeira, F.B.; Arnold, R.R.; Trope, M. Periapical inflammation after coronal microbial inoculation of dog roots filled with gutta-percha or resilon. J. Endod. 2005, 31, 91-96. [CrossRef] [PubMed]

140. Kqiku, L.; Miletic, I.; Gruber, H.J.; Anic, I.; Städtler, P. Dichtigkeit von Wurzelkanalfüllungen mit GuttaFlow und Resilon im Vergleich zur lateralen Kondensation. Wien. Med. Wochenschr. 2010, 160, 230-234. [CrossRef] [PubMed]

141. Silveira, F.F.; Soares, J.A.; Nunes, E.; Mordente, V.L. Negative influence of continuous wave technique on apical sealing of the root canal system with Resilon. J. Oral Sci. 2007, 49, 121-128. [CrossRef]

142. Kocak, M.M.; Er, O.; Saglam, B.C.; Yaman, S. Apical leakage of epiphany root canal sealer combined with different master cones. Eur. J. Dent. 2008, 2, 91-95. [CrossRef] [PubMed]

143. Bodrumlu, E.; Tunga, U. The apical sealing ability of a new root canal filling material. Am. J. Dent. 2007, 20, 295-298. [PubMed]

144. Bodrumlu, E.; Tunga, U. Coronal sealing ability of a new root canal filling material. J. Can. Dent. Assoc. 2007, 73, 623. [PubMed]

145. Bodrumlu, E.; Tunga, U. Apical leakage of Resilon obturation material. J. Contemp. Dent. Pract. 2006, 7, 45-52. [CrossRef] [PubMed]

146. Verissimo, D.M.; do Vale, M.S.; Monteiro, A.J. Comparison of apical leakage between canals filled with gutta-percha/AH-plus and Resilon/Epiphany System, when submitted to two filling techniques. J. Endod. 2007, 33, 291-294. [CrossRef]

147. Moura-Netto, C.; Pinto, T.; Davidowicz, H.; de Moura, A.A.M. Apical leakage of three resin-based endodontic sealers after 810-nm-diode laser irradiation. Photomed. Laser Surg. 2009, 27, 891-894. [CrossRef]

148. Wedding, J.R.; Brown, C.E.; Legan, J.J.; Moore, B.K.; Vail, M.M. An in vitro comparison of micro leakage between Resilon and gutta-percha with a fluid filtration model. J. Endod. 2007, 33, 1447-1449. [CrossRef]

149. Ishimura, H.; Yoshioka, T.; Suda, H. Sealing ability of new adhesive root canal filling materials measured by new dye penetration method. Dent. Mater. J. 2007, 26, 290-295. [CrossRef]

150. Nawal, R.R.; Parande, M.; Sehgal, R.; Rao, N.R.; Naik, A. A comparative evaluation of 3 root canal filling systems. Oral Surg. Oral Med. Oral Pathol. Oral Radiol. Endod. 2011, 111, 387-393. [CrossRef] 
151. Punia, S.K.; Nadig, P.; Punia, V. An in vitro assessment of apical microleakage in root canals obturated with guttaflow, Resilon, thermafil and lateral condensation: A stereomicroscopic study. J. Conserv. Dent. 2011, 14, 173-177. [CrossRef]

152. Tunga, U.; Bodrumlu, E. Assessment of the sealing ability of a new root canal obturation material. J. Endod. 2006, 32, 876-878. [CrossRef] [PubMed]

153. Shashidhar, C.; Shivanna, V.; Shivamurthy, G.; Shashidhar, J. The comparison of microbial leakage in roots filled with resilon and gutta-percha: An in vitro study. J. Conserv. Dent. 2011, 14, 21-27. [CrossRef] [PubMed]

154. Sagsen, B.; Er, O.; Kahraman, Y.; Orucoglu, H. Evaluation of micro leakage of roots filled with different techniques with a computerized fluid filtration technique. J. Endod. 2006, 32, 1168-1170. [CrossRef] [PubMed]

155. Kqiku, L.; Städtler, P.; Gruber, H.J.; Baraba, A.; Anic, I.; Miletic, I. Active versus passive microleakage of Resilon/Epiphany and gutta-percha/AH Plus. Aust. Endod. J. 2011, 37, 141-146. [CrossRef]

156. Aptekar, A.; Ginnan, K. Comparative analysis of microleakage and seal for two obturation materials: Resilon/Epiphany and gutta-percha. J. Can. Dent. Assoc. 2006, 72, 245. [PubMed]

157. Stratton, R.K.; Apicella, M.J.; Mines, P. A fluid filtration comparison of gutta-percha versus Resilon, a new soft resin endodontic obturation system. J. Endod. 2006, 32, 642-645. [CrossRef] [PubMed]

158. Kurtzman, G.M. Resilon Update. Inside Dent. 2007, 3, 1-5.

159. Siqueira, J.F.; Roças, I.N.; Favieri, A.; Abad, E.C.; Castro, A.J.; Gahyva, S.M. Bacterial leakage in coronally unsealed root canals obturated with 3 different techniques. Oral Surg. Oral Med. Oral Pathol. Oral Radiol. Endod. 2000, 90, 647-650. [CrossRef]

160. Limkangwalmongkol, S.; Burtscher, P.; Abbot, P.; Sandler, A.; Bishop, B. A comparative study of the apical leakage of four root canals sealers and laterally condensed gutta percha. J. Endod. 1991, 17, 495-499. [CrossRef]

161. Swanson, K.; Madison, S. An evaluation of coronal microleakage in endodontically treated teeth. Part 1. Time periods. J. Endod. 1987, 13, 56-59. [CrossRef]

162. Friedman, S.; Torneck, C.; Komorowsji, R.; Ouzounian, Z.; Syrtash, P.; Kaufman, A. In vivo model for assessing the functional efficacy of endodontic materials and techniques. J. Endod. 1997, 23, 557-561. [CrossRef]

163. Torabinejad, M.; Ung, B.; Kettering, J. In vitro bacterial penetration of coronally unsealed endodontically treated teeth. J. Endod. 1990, 16, 566-569. [CrossRef]

164. Shipper, G.; Trope, M. In vitro microbial leakage of endodontically treated teeth using new and standard obturation techniques. J. Endod. 2004, 30, 154-158. [CrossRef]

165. Magura, M.E.; Kafrawy, A.H.; Brown, C.E.; Newton, C.W. Human saliva coronal microleakeage in obturated root canals: An in vitro study. J. Endod. 1991, 17, 324-331. [CrossRef]

166. Oliver, C.; Abbott, P. An in vitro study of apical and coronal micro leakage of laterally condensed gutta-percha with Ketac-Endo and AH-26. Aust. Dent. J. 1998, 43, 262-268. [CrossRef]

167. Madison, S.; Wilcox, L. An evaluation of coronal microleakge in endodontically treated teeth. Part III. In vivo study. J. Endod. 1988, 14, 455-458. [CrossRef]

168. Khayat, A.; Lee, S.J.; Torabinejad, M. Human saliva penetration of coronally unsealed obturated root canals. J. Endod. 1993, 19, 458-461. [CrossRef]

169. Schilder, H. Filling root canals in three dimensions. Dent. Clin. N. Am. 1967, 723-744. [CrossRef]

170. Buchanan, L.S. The continuous wave of condensation technique: A convergence of conceptual and procedural advances in obturation. Dent. Today 1994, 13, 80, 82, 84-85.

171. Hand, R.E.; Huget, E.F.; Tsakinis, P.J. Effects of a warm gutta-percha technique on the lateral periodontium. Oral Surg. Oral Med. Oral Pathol. 1976, 42, 395-401. [CrossRef]

172. Nahmias, Y.; Mab, T.; Dovgan, J.S. The Thermo Hydraulic Condensation Technique. Oral Health 2001, 91, 11-18.

173. Nahmias, Y.; Serota, K.S.; Watson, W.R., Jr. Predictable Endodontic Success: Part II-Microstructural Replication. Available online: http:/ / www.ecoweek.ca/issues /PrinterFriendly.asp?aid=1000156065\&RType=\&PC=\&issue=12012003 (accessed on 7 May 2021).

174. Barattolo, R.; Santarcangelo, F. Otturazione del sistema dei canali radicolari con guttaperca termoplasticizzata: Principi, materiali e tecniche. G. Ital. Endod. 2011, 25, 112-124. [CrossRef]

175. Nahmias, Y.; Mab, T.; Dovgan, J.S. La tecnica di condensazione termoidraulica. L'infor. Endod. 2002, 5, $28-33$.

176. Nahmias, Y.; Bery, P. Due radici palatine nei primi molari superiori. L'infor. Endod. 2007, 10, 48-51.

177. Carvalho-Sousa, B.; Almeida-Gomes, F.; Carvalho, P.R.; Maníglia-Ferreira, C.; Gurgel-Filho, E.D.; Albuquerque, D.S. Filling lateral canals: Evaluation of different filling techniques. Eur. J. Dent. 2010, 4, 251-256. [CrossRef]

178. Kim, S.; Kim, S.; Park, J.-W.; Jung, I.-Y.; Shin, S.-J. Comparison of the Percentage of Voids in the Canal Filling of a Calcium Silicate-Based Sealer and Gutta Percha Cones Using Two Obturation Techniques. Materials 2017, 10, 1170. [CrossRef]

179. Chenxi, N.; Xia, L. Research progress on the effect of root canal sealers on root fracture resistance. Int. J. Stomatol. 2020, 47, 711-716. [CrossRef]

180. Hryniewicz, T.; Rokosz, K. On the wear inspection and endurance recovery of Nitinol endodontic files. Pomiary Autom. Kontrola 2009, 55, 247-250.

181. Hülsmann, M.; Paters, O.A.; Dummer, P.M.H. Mechanical preparation of root canals: Shaping goals, techniques and means. Endod. Top. 2005, 10, 30-76. [CrossRef]

182. Hülsmann, M.; Hahn, W. Complications during root canal irrigation-literature review and case reports. Int. Endod. J. 2000, 33, 186-193. [CrossRef] [PubMed] 
183. Gu, Y.; Kum, K.-Y.; Perinpanayagam, H.; Kim, C.; Kum, D.J.; Lim, S.-M.; Chang, S.-W.; Baek, S.-H.; Zhu, Q.; Yoo, Y.-J. Various heat-treated nickel-titanium rotary instruments evaluated in S-shaped simulated resin canals. J. Dent. Sci. 2017, 12, 14-20. [CrossRef]

184. Walia, H.M.; Brantley, W.A.; Gerstein, H. An initial investigation of the bending and torsional properties of Nitinol root canal files. J. Endod. 1988, 14, 346-351. [CrossRef]

185. Anderson, M.E.; Price, J.H.W.; Parashos, P. Fracture resistance of electropolished rotary Nickel-Titanium endodontic instruments. J. Endod. 2007, 33, 1212-1216. [CrossRef]

186. Duerig, T.; Pelton, A.; Stöckel, D. An overview of nitinol medical applications. Mater. Sci. Eng. A 1999, 273-275, 149-160. [CrossRef]

187. Buehler, W.J.; Gilfrich, J.W.; Wiley, R.C. Effects of Low-Temperature Phase Changes on the Mechanical Properties of Alloys Near Composition TiNi. J. App. Phys. 1963, 34, 1475-1477. [CrossRef]

188. Wang, F.E.; Buehler, W.J.; Pickart, S.J. Crystal Structure and a Unique Martensitic Transition of TiNi. J. App. Phys. 1965, 36, 3232-3239. [CrossRef]

189. Metallurgy: The Alloy That Remembers. Available online: http://content.time.com/time/subscriber/article/0,33009,838687,00. html (accessed on 17 August 2021).

190. Kauffman, G.B.; Mayo, I. The Story of Nitinol: The Serendipitous Discovery of the Memory Metal and Its Applications. Chem. Edu. 1997, 2, 1-21. [CrossRef]

191. Withers, N. Nitinol. Available online: https://www.chemistryworld.com/podcasts/nitinol/6710article (accessed on 10 May 2021).

192. Hryniewicz, T.; Rokosz, K.; Rokicki, R. Magnetoelectropolishing process improves characteristics of finished metal surfaces: Intensity of externally applied magnetic field, plus oxygen control, manipulates rate of dissolution in electropolishing. Met. Finish. 2006, 104, 26-33. [CrossRef]

193. Hryniewicz, T. Wstęp do Obróbki Powierzchniowej Biomateriałów Metalowych; Wyd. Politechniki Koszalińskiej: Koszalin, Poland, 2007; pp. 1-155.

194. Rokicki, R.; Hryniewicz, T. Nitinol Surface Finishing by Magnetoelectropolishing. Trans. Inst. Met. Finish. 2008, 86, 280-285. [CrossRef]

195. Hryniewicz, T.; Rokicki, R.; Rokosz, K. Modifying Metallic Implants with Magnetoelectropolishing. Med. Dev. Diagn. Indust. 2008, 30, 102-111.

196. Civjan, S.; Huget, E.F.; DeSimon, L.B. Potential applications of certain nickel-titanium (nitinol) alloys. J. Dent. Res. 1975, 54, 89-96. [CrossRef]

197. Pawlicka, H.; Ebert, J.; Prociów, A. Systematyka rotacyjnych narzędzi niklowo-tytanowych. Czas. Stomatol. 2005, 58, 709-713.

198. Product Catalog Dentsply Maillefer. Available online: https://www.maillefer.com/wp-content/uploads/2016/10/2016 -Maillefer-Catalog.pdf (accessed on 31 May 2021).

199. Schrader, C.; Ackermann, M.; Barbakow, F. Step-by-step description of a rotary root canals preparation technique. Int. Endod. J. 1999, 32, 312-320. [CrossRef]

200. Guelzow, A.; Stamm, O.; Martus, P.; Kielbassa, A.M. Comparative study of six rotary nickel-titanium systems and hand instrumentation for root canal preparation. Int. Endod. J. 2005, 38, 743-752. [CrossRef]

201. Bergmans, L.; van Cleynenbreugel, J.; Wevers, M.; Lambrechts, P. Mechanical root canal preparation with NiTi rotary instruments: Rationale, performance and safety. Status report for the American Journal of Dentistry. Am. J. Dent. 2001, 14, 324-333. [PubMed]

202. Bechelli, C.; Orlandini, S.Z.; Colafranceschi, M. Scanning electron microscope study on the efficacy of root canal wall debridement of hand versus Lightspeed instrumentation. Int. Endod. J. 1999, 32, 484-493. [CrossRef] [PubMed]

203. Tucker, D.M.; Wenckus, C.S.; Bentkover, S.K. Canal wall planning by engine-driven nickel-titanium instruments, compared with stainless steel hand instrumentation. J. Endod. 1997, 23, 170-173. [CrossRef]

204. Zuolo, M.L.; Walton, R.E. Instrument deterioration with usage: Nickel-titanium versus stainless steel. Quint. Int. 1997, 28, 397-402.

205. Tanalp, J.; Kaplan, F.; Sert, S.; Kayahan, B.; Bayirl, G. Quantitative evaluation of the amount of apically extruded debris using 3 different rotary instrumentation systems. Oral Surg. Oral Med. Oral Pathol. Oral Radiol. Endod. 2006, 101, 250-257. [CrossRef]

206. GT Rotary Files 20/.06 Yellow 25 mm. Available online: https://www.dentsplysirona.com/en-ca/products/endodontics/glidepath-shaping.html/Endodontics/Glide-Path-\%26-Shaping/Rotary-\%26-Reciprocating-Files/Shaping/GT-Rotary-Files /p/ TUL-GTR0602025/c/1000671.html (accessed on 7 May 2021).

207. ASTM 2063 Shape Memory Ni Ti Alloy Nitinol 55 Nitinol 60 Wire. Available online: https:/ /www.nitinolcn.com/showroom/ astm-2063-shape-memory-ni-ti-alloy-nitinol-55-nitinol-60-wire.html (accessed on 7 May 2021).

208. Massalski, T.B.; Okamoto, H.; Subramanian, P.R.; Kacprzak, L. (Eds.) Binary Alloys Phase Diagrams, 2nd ed.; ASM International: Materials Park, OH, USA, 1990; Volume 3, pp. 1-2875.

209. Honma, T.; Matsumoto, T.; Shugo, Y.; Nishida, M. Annual Research Report. Res. Rep. Nucl. Sci. Lab. Tohoku Univ. 1979, 12, 183-190.

210. Nishida, M.; Wayman, C.M.; Honma, T. Electron microscopy studies of the $\mathrm{Ti}_{11} \mathrm{Ni}_{14}$ phase in an aged Ti-52.0at $\% \mathrm{Ni}$ shape memory alloy. Scr. Metall. 1985, 19, 983-987. [CrossRef] 
211. Tadaki, T.; Nakata, Y.; Shimizu, K.; Otsuka, K. Crystal Structure, Composition and Morphology of a Precipitate in an Aged Ti-51 at\%Ni Shape Memory Alloy. Trans. JIM 1986, 27, 731-740. [CrossRef]

212. Saburi, T.; Nenno, S.; Fukuda, T. Crystal structure and morphology of the metastable X phase in shape memory Ti-Ni alloys. J. Less Com. Met. 1986, 125, 157-166. [CrossRef]

213. Kai, W.-Y.; Chang, K.-C.; Wu, H.-F.; Chen, S.-W.; Yeh, A.-C. Formation mechanism of Ni2Ti4Ox in NITI shape memory alloy. Materialia 2019, 5, 100194. [CrossRef]

214. ASTM F2063-18. Standard Specification for Wrought Nickel-Titanium Shape Memory Alloys for Medical Devices and Surgical Implants; ASTM International: West Conshohocken, PA, USA, 2018.

215. Bojarski, Z.; Morawiec, H. Metale z Pamięcia Kształtu; PWN: Warszawa, Poland, 1989.

216. Hanlon, J.E.; Butler, S.R.; Wasilewski, R.J. Effect of martensitic transformation on the electrical and magnetic properties of NiTi. Trans. Metall. Soc. AIME 1967, 239, 1323-1327.

217. Harrison, J.D.; Hodgson, D.E. Use of TiNi in Mechanical and Electrical Connectors. In Shape Memory Effects in Alloys; Perkins, J., Ed.; Plenum Press: New York, NY, USA, 1975; pp. 517-523. [CrossRef]

218. Dobrzański, L.A.; Dobrzański, L.B.; Dobrzańska, J.; Dobrzański, J.; Jung, T. Application of nitinol type alloys in teeth endodontic treatment. Processes 2021, 9, 926.

219. Lin, Z.; Pike, K.; Schlun, M.; Zipse, A.; Draper, J. Nitinol Fatigue Life for Variable Strain Amplitude Fatigue. J. Mater. Eng. Perform. 2012, 21, 2628-2632. [CrossRef]

220. Thompson, S.A.; Dummer, P.M. Shaping ability of Quantec Series 2000 rotary nickel-titanium instruments in simulated root canals: Part 2. Int. Endod. J. 1998, 31, 268-274. [CrossRef] [PubMed]

221. Lin, Z.; Pike, K.; Zipse, A.; Schlun, M. Nitinol Fatigue Investigation on Stent-Finish Specimens Using Tension-Tension Method. J. Mater. Eng. Perform. 2011, 20, 591-596. [CrossRef]

222. Rahim, M.; Frenzel, J.; Frotscher, M.; Pfetzing-Micklich, J.; Steegmüller, R.; Wohlschlögel, M.; Mughrabi, H.; Eggeler, G. Impurity levels and fatigue lives of pseudoelastic NiTi shape memory alloys. Acta Mater. 2013, 61, 3667-3686. [CrossRef]

223. Urbano, M.F.; Coda, A.; Beretta, S.; Cadelli, A.; Sczerzenie, F. The Effect of Inclusions on Fatigue Properties for Nitinol. In Fatigue and Fracture Metallic Medical Materials and Devices; Mitchell, M., Smith, S., Woods, T., Berg, B., Eds.; ASTM International: West Conshohocken, PA, USA, 2013; pp. 18-34. [CrossRef]

224. Robertson, S.W.; Launey, M.; Shelley, O.; Ong, I.; Vien, L.; Senthilnathan, K.; Saffari, P.; Schlegel, S.; Pelton, A.R. A statistical approach to understand the role of inclusions on the fatigue resistance of superelastic Nitinol wire and tubing. J. Mech. Behav. Biomed. Mater. 2015, 51, 119-131. [CrossRef]

225. Launey, M.; Robertson, S.W.; Vien, L.; Senthilnathan, K.; Chintapalli, P.; Pelton, A.R. Influence of microstructural purity on the bending fatigue behavior of VAR-melted superelastic Nitinol. J. Mech. Behav. Biomed. Mater. 2014, 34, 181-186. [CrossRef]

226. Yoneyama, T.; Doi, H.; Hamanaka, H.; Okamoto, Y.; Mogi, M.; Miura, F. Super-elasticity and thermal behavior of Ni-Ti alloy orthodontic arch wires. Dent. Mater. J. 1992, 11, 1-10. [CrossRef] [PubMed]

227. Wang, F.E.; Pickart, S.J.; Alperin, H.A. Mechanism of the TiNi martensitic transformation and the crystal structures of TiNi-II and TiNi-III phases. J. Appl. Phys. 1972, 43, 97-112. [CrossRef]

228. Schäfer, E. Root canal instruments for manual use: A review. Dent. Traumatol. 1997, 13, 51-64. [CrossRef] [PubMed]

229. Pelton, A.R.; Russell, S.M.; DiCello, J. The physical metallurgy of nitinol for medical applications. JOM 2003, 55, 33-37. [CrossRef]

230. Hryniewicz, T.; Rokicki, R. Improved surface properties of nitinol after magnetoelectropolishing. In Proceedings of the 16th Annual International Conference on Composites/Nano-Engineering “ICCE-16", Kunming, China, 20-26 July 2008.

231. Hryniewicz, T. Biomaterials surface improvement by magnetoelectropolishing. In Proceedings of the BIT Life Sciences' 1st Annual World Congress of IBIO2008, New Starting Line for Decision Makers in Bioeconomy Era, Hangzhou, China, 18-22 May 2008.

232. Chekotu, J.C.; Groarke, R.; O’Toole, K.; Brabazon, D. Advances in Selective Laser Melting of Nitinol Shape Memory Alloy Part Production. Materials 2019, 12, 809. [CrossRef]

233. Zhang, X.; Qian, M.; Zhu, X.; Shang, C.; Geng, L. Elastocaloric effects in ultra-fine grained NiTi microwires processed by cold-drawing. APL Mater. 2018, 6, 036102. [CrossRef]

234. Świec, P.; Zubko, M.; Lekston, Z.; Stróż, D. Structure and properties of NiTi shape memory alloy after cold rolling in martensitic state. Acta Phys. Pol. A 2016, 130, 1081-1084. [CrossRef]

235. Burow, J.; Frenzel, J.; Somsen, C.; Prokofiev, E.; Valiev, R.; Eggeler, G. Grain nucleation and growth in deformed NiTi shape memory alloys: An in situ TEM study. Shap. Mem. Superelast. 2017, 3, 347-360. [CrossRef]

236. Tong, Y.X.; Hu, K.P.; Chen, F.; Tian, B.; Li, L.; Zheng, Y.F. Multiple-stage transformation behavior of Ti49.2Ni50.8 alloy with different initial microstructure processed by equal channel angular pressing. Intermetallics 2017, 85, 163-169. [CrossRef]

237. Wang, X.; Kustov, S.; Verlinden, B.; Van Humbeeck, J. Fundamental development on utilizing the R-phase transformation in NiTi shape memory alloys. Shap. Mem. Superelast. 2015, 1, 231-239. [CrossRef]

238. Shamimi, A.; Amin-Ahmadi, B.; Stebner, A.; Duerig, T. The effect of low temperature aging and the evolution of R-phase in Ni-rich NiTi. Shap. Mem. Superelast. 2018, 4, 417-427. [CrossRef]

239. Wang, Z.; Everaerts, J.; Salvati, E.; Korsunsky, A.M. Evolution of thermal and mechanical properties of Nitinol wire as a function of ageing treatment conditions. J. Alloys Compd. 2020, 819, 153024. [CrossRef]

240. Chad Hornbuckle, B.; Yu, X.X.; Noebe, R.D.; Martens, R.; Weaver, M.L.; Thompson, G.B. Hardening behavior and phase decomposition in very Ni-rich Nitinol alloys. Mater. Sci. Eng. A 2015, 639, 336-344. [CrossRef] 
241. Velmurugan, C.; Senthilkumar, V.; Dinesh, S.; Arulkirubakaran, D. Review on phase transformation behavior of NiTi shape memory alloys. Mater. Today Proc. 2018, 5, 14597-14606. [CrossRef]

242. Liang, X.; Xiao, F.; Chen, H.; Li, Z.; Li, Z.; Jin, X.; Fukuda, T. Internal friction of the R-phase in single crystalline Ti-50.8Ni (at.\%) alloy containing controlled precipitate of $\mathrm{Ti}_{3} \mathrm{Ni}_{4}$. Scr. Mater. 2019, 166, 44-47. [CrossRef]

243. Pourbabak, S.; Orekhov, A.; Samaee, V.; Verlinden, B.; Van Humbeeck, J.; Schryvers, D. In-Situ TEM stress induced martensitic transformation in $\mathrm{Ni}_{50.8} \mathrm{Ti}_{49.2}$ microwires. Shap. Mem. Superelast. 2019, 5, 154-162. [CrossRef]

244. Gurley, A.; Lambert, T.R.; Beale, D.; Broughton, R. Dual measurement self-sensing technique of NiTi actuators for use in robust control. Smart Mater. Struct. 2017, 26, 105050. [CrossRef]

245. Dilibal, S.; Sahin, H.; Dursun, E.; Engeberg, E.D. Nickel-titanium shape memory alloy-actuated thermal overload relay system design. Electr. Eng. 2017, 99, 923-930. [CrossRef]

246. Mehrpouya, M.; Gisario, A.; Broggiato, G.B.; Puopolo, M.; Vesco, S.; Barletta, M. Effect of welding parameters on functionality of dissimilar laser-welded NiTi superelastic (SE) to shape memory effect (SME) wires. Int. J. Adv. Manuf. Technol. 2019, 103, 1593-1601. [CrossRef]

247. Casati, R.; Saghafi, F.; Biffi, C.A.; Vedani, M.; Tuissi, A. Improved functional properties and efficiencies of nitinol wires under high-performance shape memory effect (HP-SME). J. Mater. Eng. Perform. 2017, 26, 4964-4969. [CrossRef]

248. Dobrzański, L.A. Metale i ich Stopy. In Open Access Library VII(2); Dobrzański, L.A., Ed.; International OCSCO World Press: Gliwice, Poland, 2017; pp. 1-982.

249. Fan, G.; Chen, W.; Yang, S.; Zhu, J.; Ren, X.; Otsuka, K. Origin of abnormal multi-stage martensitic transformation behavior in aged Ni-rich Ti-Ni shape memory alloys. Acta Mater. 2004, 52, 4351-4362. [CrossRef]

250. Otsuka, K.; Ren, X. Physical Metallurgy of Ti-Ni-based Shape Memory Alloys. Prog. Mater. Sci. 2005, 50, 511-678. [CrossRef]

251. Chluba, C.; Ge, W.; Lima de Miranda, R.; Strobel, J.; Kienle, L.; Quandt, E.; Wuttig, M. Shape memory alloys. Ultralow-fatigue shape memory alloy films. Science 2015, 348, 1004-1007. [CrossRef]

252. Spini, T.S.; Valarelli, F.P.; Cançado, R.H.; Freitas, K.M.; Villarinho, D.J. Transition temperature range of thermally activated nickel-titanium archwires. J. Appl. Oral. Sci. 2014, 22, 109-117. [CrossRef] [PubMed]

253. Funakubo, H. Shape Memory Alloys; University of Tokyo: Tokyo, Japan, 1984; p. 7.

254. Sadiq, H.; Wong, M.B.; Al-Mahaidi, R.; Zhao, X.L. The effects of heat treatment on the recovery stresses of shape memory alloys. Smart Mater. Struct. 2010, 19, 035021. [CrossRef]

255. ASTM E8/E8M-21. Standard Test. Methods for Tension Testing of Metallic Materials; ASTM International: West Conshohocken, PA, USA, 2021

256. Ren, X.; Miura, N.; Taniwaki, K.; Otsuka, K.; Suzuki, T.; Tanaka, K.; Chumlyakov, Yu.I.; Asai, M. Understanding the martensitic transformations in TiNi-based alloys by elastic constants measurement. Mater. Sci. Eng. A 1999, 273-275, 190-194. [CrossRef]

257. Wang, X.; VerlinDen, B.; Kustov, S. Multi-stage martensitic transformation in Ni-rich NiTi shape memory alloys. Funct. Mater. Lett. 2017, 10, 1-8. [CrossRef]

258. Fan, G.; Zhou, Y.; Chen, W.; Yang, S.; Ren, X.; Otsuka, K. Precipitation kinetics of $\mathrm{Ti}_{3} \mathrm{Ni}_{4}$ in polycrystalline Ni-rich TiNi alloys and its relation to abnormal multi-stage transformation behavior. Mater. Sci. Eng. A 2006, 438-440, 622-626. [CrossRef]

259. Nishida, M.; Wayman, C.M.; Kainuma, R.; Honma, T. Further electron microscopy studies of the $\mathrm{Ti}_{11} \mathrm{Ni}_{14}$ phase in an aged Ti-52at\%Ni shape memory alloy. Scr. Metall. 1986, 20, 899-904. [CrossRef]

260. Nishida, M.; Wayman, C.M.; Honma, T. Precipitation processes in near-equiatomic TiNi shape memory alloys. Metall. Mater. Trans. A 1986, 17, 1505-1515. [CrossRef]

261. Khalil-Allafi, J.; Eggeler, G.; Dlouhy, A.; Schmahl, WW.; Somsen, C.H. On the influence of heterogeneous precipitation on martensitic transformations in a Ni-rich NiTi shape memory alloy. Mater. Sci. Eng. A 2004, 378, 148-151. [CrossRef]

262. Liu, S.; Zhu, J.; Lin, X.; Wang, X.; Wang, G. Coupling effect of stretch-bending deformation and electric pulse treatment on phase transformation behavior and superelasticity of a Ti-50.8 at.\% Ni alloy. Mater. Sci. Eng. A 2021, 799, 140164. [CrossRef]

263. Hirsch, P.; Howie, A.; Nicholson, R.B.; Pashley, D.W.; Whelan, M.J. Electron Microscopy of Thin Crystals, 2nd ed.; Krieger Publishing Company: Malabar, FL, USA, 1977; pp. 169, 317.

264. Honma, T. The effect of aging, on the spontaneous shape change and the all-round shape memory effect in Ni-rich TiNi alloy. In Proceedings of the International Conference on Martensitic Transformations ICOMAT-86, Nara, Japan, 26-30 August 1986; pp. 709-716.

265. Kainuma, R.; Matsumoto, M.; Honma, T. The mechanism of the all-round shape memory effect in a Ni-rich TiNi alloy. In Proceedings of the International Conference on Martensitic Transformations ICOMAT-86, Nara, Japan, 26-30 August 1986; pp. 717-722.

266. Koskimaki, D.; Marcinkowski, M.J.; Sastri, A.S. Solid State Diffusional Transformations in the Near Equiatomic Ni-Ti Alloys. Trans. Metall. Soc. AIME 1969, 245, 1883-1890.

267. Chen, Q.; $\mathrm{Wu}$, X.F.; Ko, T. The effects of $\mathrm{Ti}_{3} \mathrm{Ni}_{4}$ precipitates on the R-phase transformation. Scr. Metall. Mater. 1993, $29,49-53$. [CrossRef]

268. Xie, C.Y.; Zhao, L.C.; Lei, T.C. Effect of precipitates on the electrical resistivity-temperature curves in an aged Ti-51.8 at \% Ni shape memory alloy. Scr. Metall. 1989, 23, 2131-2136. [CrossRef]

269. Xie, C.Y.; Zhao, L.C.; Lei, T.C. Effect of $\mathrm{Ti}_{3} \mathrm{Ni}_{4}$ precipitates on the phase transitions in an aged Ti-51.8at\% Ni shape memory alloy. Scr. Metall. Mater. 1990, 24, 1753-1758. [CrossRef] 
270. Khalil-Allafi, J.; Ren, X.; Eggeler, G. The mechanism of multistage martensitic transformations in aged Ni-rich NiTi shape memory alloys. Acta Mater. 2002, 50, 793-803. [CrossRef]

271. Zou, W.H.; Han, X.D.; Wang, R.; Zhang, Z.; Zhang, W.-Z.; Lai, J.K.L. TEM and HREM study of the interphase interface structure of $\mathrm{Ti}_{3} \mathrm{Ni}_{4}$ precipitates and parent phase in an aged TiNi shape memory alloy. Mater. Sci. Eng. A 1996, 219, 142-147. [CrossRef]

272. Van Humbeeck, J. Non-medical applications of shape memory alloys. Mater. Sci. Eng. A 1999, 273-275, 134-148. [CrossRef]

273. Wang, X.; Li, K.; Schryvers, D.; Verlinden, B.; Van Humbeeck, J. R-phase transition and related mechanical properties controlled by low-temperature aging treatment in a Ti-50.8at.\% Ni thin wire. Scr. Mater. 2014, 72-73, 21-24. [CrossRef]

274. Dautovich, D.P.; Purdy, G.R. Phase Transformations in TiNi. Canad. Metall. Quart. 1965, 4, 129-143. [CrossRef]

275. Miyazaki, S.; Otsuka, K. Deformation and transition behavior associated with the R-phase in Ti-Ni alloys. Metall. Mater. Trans. A 1986, 17, 53-63. [CrossRef]

276. Miyazaki, S.; Kimura, S.; Otsuka, K. Shape-memory effect and pseudoelasticity associated with the R-phase transition in Ti-50.5 at.\% Ni single crystals. Philos. Mag. A 1988, 57, 467-478. [CrossRef]

277. Hara, T.; Ohba, T.; Okunishi, E.; Otsuka, K. Structural Study of R-Phase in Ti-50.23 at.\%Ni and Ti-47.75 at.\%Ni-1.50 at.\%Fe Alloys. Mater. Trans. JIM 1997, 38, 11-17. [CrossRef]

278. Tirry, W.; Schryvers, D. Quantitative determination of strain fields around $\mathrm{Ni}_{4} \mathrm{Ti}_{3}$ precipitates in NiTi. Acta Mater. 2005, 53, 1041-1049. [CrossRef]

279. Karaca, H.E.; Kaya, I.; Tobe, H.; Basaran, B.; Nagasako, M.; Kainuma, R.; Chumlyakov, Y. Shape memory behavior of high strength Ni54Ti46 alloys. Mater. Sci. Eng. A 2013, 580, 66-70. [CrossRef]

280. Wang, X.; Li, C.; Verlinden, B.; Van Humbeeck, J. Effect of grain size on aging microstructure as reflected in the transformation behavior of a low-temperature aged Ti-50.8 at.\% Ni alloy. Scr. Mater. 2013, 69, 545-548. [CrossRef]

281. Šittner, P.; Landa, M.; Lukáš, P.; Novák, V. R-phase transformation phenomena in thermomechanically loaded NiTi polycrystals. Mech. Mater. 2006, 38, 475-492. [CrossRef]

282. Ha, J.H.; Kim, S.K.; Cohenca, N.; Kim, H.C. Effect of R-phase heat treatment on torsional resistance and cyclic fatigue fracture. J. Endod. 2013, 39, 389-393. [CrossRef]

283. Pelton, A.R.; Huang, G.H.; Moine, P.; Sinclair, R. Effects of thermal cycling on microstructure and properties in Nitinol. Mater. Sci. Eng. A 2012, 532, 130-138. [CrossRef]

284. Tobushi, H.; Yamada, S.; Hachisuka, T.; Ikai, A.; Tanaka, K. Thermomechanical properties due to martensitic and R-phase transformations of TiNi shape memory alloy subjected to cyclic loadings. Smart Mater. Struct. 1996, 5, 788. [CrossRef]

285. Uchil, J.; Kumara, K.G.; Mahesh, K.K. Effect of thermal cycling on R-phase stability in a NiTi shape memory alloy. Mater. Sci. Eng. A 2002, 332, 25-28. [CrossRef]

286. Miyazaki, S.; Igo, Y.; Otsuka, K. Effect of thermal cycling on the transformation temperatures of Ti-Ni alloys. Acta Metall. 1986, 34, 2045-2051. [CrossRef]

287. Tobushi, H.; Kimura, K.; Sawada, T.; Hattori, T.; Lin, P.H. Recovery Stress Associated with R-Phase Transformation in TiNi Shape Memory Alloy: Properties under Constant Residual Strain. JSME Int. J. A 1994, 37, 138-142. [CrossRef]

288. Miyazaki, S.; Otsuka, K. Mechanical behaviour associated with the premartensitic rhombohedral-phase transition in a $\mathrm{Ti}_{50} \mathrm{Ni}_{47} \mathrm{Fe}_{3}$ alloy. Philos. Mag. A 1985, 50, 393-408. [CrossRef]

289. Huang, X.; Liu, Y. Effect of annealing on the transformation behavior and superelasticity of NiTi shape memory alloy. Scr. Mater. 2001, 45, 153-160. [CrossRef]

290. Gall, K.; Tyber, J.; Wilkesanders, G.; Robertson, S.W.; Ritchie, R.O.; Maier, H.J. Effect of microstructure on the fatigue of hot-rolled and cold-drawn NiTi shape memory alloys. Mater. Sci. Eng. A 2008, 486, 389-403. [CrossRef]

291. Nishida, M.; Wayman, C.M. Electron microscopy studies of the "Premartensitic" transformations in an aged Ti-51 at\%Ni shape memory alloy. Metallography 1988, 21, 255-273. [CrossRef]

292. Favier, D.; Liu, Y.; McCormick, P.G. Three stage transformation behaviour in aged NiTi. Scr. Metall. Mater. 1993, $28,669-672$. [CrossRef]

293. Liu, X.; Wang, Y.; Yang, D.; Qi, M. The effect of ageing treatment on shape-setting and superelasticity of a nitinol stent. Mater. Charact. 2008, 59, 402-406. [CrossRef]

294. Matsumoto, H. Appearance of an intermediate phase with thermal cycling on the transformation of NiTi. J. Mater. Sci. Lett. 1991, 10, 408-410. [CrossRef]

295. Matsumoto, H. Transformation behaviour with thermal cycling in NiTi alloys. J. Alloys Compd. 2003, 350, 213-217. [CrossRef]

296. Dilibal, S.; Hamilton, R.F.; Lanba, A. The effect of employed loading mode on the mechanical cyclic stabilization of NiTi shape memory alloys. Intermetallics 2017, 89, 1-9. [CrossRef]

297. Piekielny, M.; Jarmołowicz, M.; Dobrzyński, M. Odporność na cykliczne zmęczenie wybranych endodontycznych narzędzi maszynowych w świetle piśmiennictwa. Inż. Fiz. Med. 2020, 9, 143-144.

298. Cao, S.; Nishida, M.; Schryvers, D. Quantitative three-dimensional analysis of $\mathrm{Ni}_{4} \mathrm{Ti}_{3}$ precipitate morphology and distribution in polycrystalline Ni-Ti. Acta Mater. 2011, 59, 1780-1789. [CrossRef]

299. Xue, D.; Zhou, Y.; Ren, X. The effect of ageing on the B2-R transformation behaviors in Ti-51at\%Ni alloy. Intermetallics 2011, 19, 1752-1758. [CrossRef]

300. Jordan, L.; Chandrasekaran, M.; Masse, M.M.; Bouquet, G. Study of the phase transformation in Ni-Ti based shape memory alloys. J. Phys. IV Fr. 1995, 5, C2-489-C2-494. [CrossRef] 
301. Khalil-Allafi, J.; Eggeler, G.; Schmahl, W.W. Quantitative phase analysis in microstructures which display multiple step martensitic transformations in Ni-rich NiTi shape memory alloys. Mater. Sci. Eng. A 2006, 438-440, 593-596. [CrossRef]

302. Pushin, V.G.; Stolyarov, V.V.; Valiev, R.Z.; Lowe, T.C.; Zhu, Y.T. Nanostructured TiNi based shape memory alloys processed by severe plastic deformation. Mater. Sci. Eng. 2005, 410-411, 386-389. [CrossRef]

303. Moon, H.-J.; Chun, S.-J.; Liu, Y.; Yang, H.; Kim, Y.-W.; Nam, T.-H. Effect of alloy composition on the B2-R transformation in rapidly solidified Ti-Ni alloys. J. Alloys Compd. 2013, 577, S259-S264. [CrossRef]

304. Kim, J.I.; Liu, Y.; Miyazaki, S. Ageing-induced two-stage R-phase transformation in Ti-50.9at.\%Ni. Acta Mater. 2004, 52, 487-499. [CrossRef]

305. Rapisarda, E.; Bonaccorso, A.; Tripi, T.R.; Condorelli, G.G. Effect of sterilization on the cutting efficiency of rotary nickel-titanium endodontic files. Oral Surg. Oral Med. Oral Pathol. Oral Radiol. Endod. 1999, 88, 343-347. [CrossRef]

306. Plotino, G.; Costanzo, A.; Grande, N.M.; Petrovic, R.; Testarelli, L.; Gambarini, G. Experimental Evaluation on the Influence of Autoclave Sterilization on the Cyclic Fatigue of New Nickel-Titanium Rotary Instruments. J. Endod. 2012, 38, 222-225. [CrossRef]

307. la Chapelle, C.F.; Veersema, S.; Brölmann, H.A.M.; Jansen, F.W. Effectiveness and feasibility of hysteroscopic sterilization techniques: A systematic review and meta-analysis. Fertil. Steril. 2015, 103, 1516-1525.e3. [CrossRef]

308. Dioguardi, M.; Laneve, E.; Di Cosola, M.; Cazzolla, A.P.; Sovereto, D.; Aiuto, R.; Laino, L.; Leanza, T.; Alovisi, M.; Troiano, G.; et al. The Effects of Sterilization Procedures on the Cutting Efficiency of Endodontic Instruments: A Systematic Review and Network Meta-Analysis. Materials 2021, 14, 1559. [CrossRef] [PubMed]

309. Schafer, E. Effect of sterilization on the cutting efficiency of PVD-coated nickel-titanium endodontic instruments. Int. Endod. J. 2002, 35, 867-872. [CrossRef] [PubMed]

310. Seago, S.T.; Bergeron, B.E.; Kirkpatrick, T.C.; Roberts, M.D.; Roberts, H.W.; Himel, V.T.; Sabey, K.A. Effect of Repeated Simulated Clinical Use and Sterilization on the Cutting Efficiency and Flexibility of Hyflex CM Nickel-Titanium Rotary Files. J. Endod. 2015, 41, 725-728. [CrossRef] [PubMed]

311. Haïkel, Y.; Serfaty, R.; Wilson, P.; Speisser, J.M.; Allemann, C. Cutting efficiency of nickel-titanium endodontic instruments and the effect of sodium hypochlorite treatment. J. Endod. 1998, 24, 736-739. [CrossRef]

312. Neal, R.G.; Craig, R.G.; Powers, J.M. Effect of sterilization and irrigants on the cutting ability of stainless steel files. J. Endod. 1983, 9, 93-96. [CrossRef]

313. Morrison, S.W.; Newton, C.W.; Brown, C.E. The effects of steam sterilization and usage on cutting efficiency of endodontic instruments. J. Endod. 1989, 15, 427-431. [CrossRef]

314. Haïkel, Y.; Serfaty, R.; Lwin, T.T.; Allemann, C. Measurement of the cutting efficiency of endodontic instruments: A new concept. J. Endod. 1996, 22, 651-656. [CrossRef]

315. Webber, J.; Moser, J.B.; Heuer, M.A. A method to determine the cutting efficiency of root canal instruments in linear motion. J. Endod. 1980, 6, 829-834. [CrossRef]

316. Villalobos, R.L.; Moser, J.B.; Heuer, M.A. A method to determine the cutting efficiency of root canal instruments in rotary motion. J. Endod. 1980, 6, 667-671. [CrossRef]

317. Molven, O. A comparison of the dentin-removing ability of five root canal instruments. Scand. J. Dent. Res. 1970, 78, 500-511. [CrossRef] [PubMed]

318. Oliet, S.; Sorin, S.M. Cutting efficiency of endodontic reamers. Oral Surg. Oral Med. Oral Pathol. 1973, 36, 243-252. [CrossRef]

319. Fromme, H.G.; Riedel, H. Treatment of Dental Root Canals and the Marginal Contact between Filling Material and Tooth, studied by Scanning Electronic Microscopy. Int. Endod. J. 1972, 6, 17-20. [CrossRef] [PubMed]

320. Stefanescu, T.; Popovici, R.A.; Antoniac, I.V.; Galuscan, A.; Tirca, T. Ni-Ti Rotary Instrument Fracture Analysis after Clinical Use. Structure Changes in Used Instruments. Environ. Eng. Manag. J. 2016, 15, 981-988. [CrossRef]

321. Matei, A.; Pencea, I.; Stanciu, S.; Hristu, R.; Antoniac, I.; Coman, E.C.; Sfat, C.; Stanciu, G. Structural characterization and adhesion appraisal of TiN and TiCN coatings deposited by CAE-PVD technique on a new carbide composite cutting tool. J. Adhes. Sci. Technol. 2015, 29, 2576-2589. [CrossRef]

322. Inan, U.; Keskin, C. Torsional Resistance of ProGlider, Hyflex EDM, and One G Glide Path Instruments. J. Endod. 2019, 45, 1253-1257. [CrossRef]

323. Spagnuolo, G.; Ametrano, G.; d'Antò, V.; Rengo, C.; Simeone, M.; Riccitiello, F.; Amato, M. Effect of autoclaving on the surfaces of TiN-coated and conventional nickel-titanium rotary instruments. Int. Endod. J. 2012, 45, 1148-1155. [CrossRef]

324. Razavian, H.; Iranmanesh, P.; Mojtahedi, H.; Nazeri, R. Effect of Autoclave Cycles on Surface Characteristics of S-File Evaluated by Scanning Electron Microscopy. Iran. Endod. J. 2015, 11, 29-32. [CrossRef]

325. Nair, A.S.; Tilakchand, M.; Naik, B.D. The effect of multiple autoclave cycles on the surface of rotary nickel-titanium endodontic files: An in vitro atomic force microscopy investigation. J. Conserv. Dent. 2015, 18, 218-222.

326. Fayyad, D.M.; Elgendy, A.A.E. Cutting Efficiency of Twisted versus Machined Nickel-Titanium Endodontic Files. J. Endod. 2011, 37, 1143-1146. [CrossRef]

327. Hilt, B.R.; Cunningham, C.J.; Shen, C.; Richards, N. Torsional Properties of Stainless-Steel and Nickel-Titanium Files After Multiple Autoclave Sterilizations. J. Endod. 2000, 26, 76-80. [CrossRef] [PubMed]

328. Siqueira, J.F.; Rôcas, I.N.; Favieri, A.; Lima, K.C. Chemomechanical reduction of the bacterial population in the root canal instrumentation and irrigation with $1 \%, 2,5 \%$ and 5,25\% sodium hypochlorite. J. Endod. 2000, 26, 331-334. [CrossRef] [PubMed] 
329. Saleh, A.A.; Ettaman, W.M. Effect of endodontic irrigation solutions on microhardness of root canal dentine. J. Dent. 1999, 27, 43-46. [CrossRef]

330. Walsh, L.J.; George, R. Activation of Alkaline Irrigation Fluids in Endodontics. Materials 2017, 10, 1214. [CrossRef] [PubMed]

331. Sim, T.P.; Knowles, J.C.; Ng, Y.L.; Shelton, J.; Gulabivala, K. Effect of sodium hypochlorite on mechanical properties of dentine and tooth surface strain. Int. Endod. J. 2001, 34, 120-132. [CrossRef]

332. Hart, J.R. Ethylenediaminetetraacetic Acid and Related Chelating Agents. In Ullmann's Encyclopedia of Industrial Chemistry; Ullmann, F., Ed.; Wiley-VCH: Weinheim, Germany, 2000. [CrossRef]

333. Wujec, P.; Pawlicka, H. Standardowe środki płuczące polecane w leczeniu endodontycznym-Przegląd piśmiennictwa. Dent. Med. Probl. 2008, 45, 466-472.

334. Heling, I.; Irani, E.; Karni, S.; Steinberg, D. In vitro antimicrobial effect of RC-Prep within dentinal tubules. J. Endod. 1999, 25, 782-785. [CrossRef]

335. Morris, M.D.; Lee, K.W.; Bouillaguet, S.; Pashley, D.H. Effects of sodium hypochlorite and RC-Prep on bond strenghts of resin cement to endodontic surfaces. J. Endod. 2001, 27, 753-757. [CrossRef] [PubMed]

336. Wu, M.K.; Wesselink, P.R. A primary observation on the preparation and obturation of oval canals. Int. Endod. J. 2001, 34, 137-141. [CrossRef]

337. Peters, L.B.; Wesselink, P.R.; Moorer, W.R. The fate and the role of bacteria left in root dentinal tubules. Int. Endod. J. 1995, 28, 95-99. [CrossRef] [PubMed]

338. Shahi, S.; Zand, V.; Oskoee, S.S.; Abdolrahimi, M.; Rahnema, A.H. An in vitro study of the effect of spreader penetration depth and apical microleakage. J. Oral Sci. 2007, 49, 283-286. [CrossRef] [PubMed]

339. Silva, D.; Endal, U.; Reynaud, A.; Portenier, I.; Ǿstravik, D.; Haapasalo, M. A comparative study of lateral condensation, heat-softened gutta-percha and modified master cone heat-softened backfilling technique. Int. Endod. J. 2002, 35, 1005-1111. [CrossRef] [PubMed]

340. Nielsen, B.A.; Baumgartner, J.C. Spreader penetration during lateral compaction of resilon and gutta-percha. J. Endod. 2006, 32, 52-54. [CrossRef] [PubMed]

341. Johnson, W.B. A new gutta-percha technique. J. Endod. 1978, 4, 184-188. [CrossRef]

342. Tani-Ishii, N.; Teranka, T. Clinical and radiographic evaluation of root-canal obturation with Obtura II. J. Endod. 2003, 29, 739-742. [CrossRef]

343. Goldberg, F.; Artaza, L.P.; De Silvio, A. Effectiveness of different obturation techniques in the filling of simulated lateral canals. J. Endod. 2001, 27, 362-364. [CrossRef] [PubMed]

344. De Deus, G.; Gurgel-Filho, E.D.; Magalhaes, K.M.; Countinho-Filho, T. A laboratory of gutta-percha filled area obtained using Thermafil, System B and Lateral condensation. Int. Endod. J. 2006, 39, 378-383. [CrossRef] [PubMed]

345. Pawińska, M.; Kierklo, A. Ocena jakości wypełnień kanałowych w aspekcie przylegania i szczelności na podstawie obrazów mikroskopowych SEM. Czas. Stomatol. 2009, 62, 5-13.

346. Buchanan, S.L. The continuous wave of obturation technique: "Centered" condensation of warm gutta-percha in 12 seconds. Dent. Today 1996, 15, 60-67.

347. Bugea, C. Continuous Wave of Condensation. Available online: http://endodontics.styleitaliano.org/continuous-wave-ofcondensation/ (accessed on 17 May 2021).

348. Barbosa, F.O.G.; Gusman, H.; Pimenta de Araujo, M.C. A comparative study on the frequency location and direction of accessory canals filled with the hydraulic vertical condensation and continuous wave of condensation techniques. J. Endod. 2009, 35, 397-400. [CrossRef]

349. Nahmias, Y.; Mab, T.; Dovgan, J.S. The Thermo-Hydraulic Condensation Technique. Available online: https://www. endoexperience.com/documents/YTHTTechnique2001.pdf (accessed on 17 May 2021).

350. DuLac, K.A.; Nielsen, C.J.; Tomazic, T.J.; Ferrillo, P.J.; Hatton, J.F. Comparison of the obturation of lateral canals by six techniques. J. Endod. 1999, 25, 376-380. [CrossRef]

351. Cassai, E. THERMAFIL: The Technique Step by Step. Available online: http://endodontics.styleitaliano.org/thermafil-thetechnique-step-by-step/ (accessed on 17 May 2021).

352. Faus-Llácer, V.; Pérez, R.L.; Faus-Matoses, I.; Ruiz-Sánchez, C.; Zubizarreta-Macho, Á.; Sauro, S.; Faus-Matoses, V. Efficacy of Removing Thermafil and GuttaCore from Straight Root Canal Systems Using a Novel Non-Surgical Root Canal Re-Treatment System: A Micro-Computed Tomography Analysis. J. Clin. Med. 2021, 10, 1266. [CrossRef]

353. Lipski, M.; Lichota, D.; Woźniak, K. Evaluation of the controlled placement of Thermafil obturators. In Proceedings of the 9th Biennial Congress of the European Society of Endodontology, Zagreb, Croatia, 7-9 October 1999.

354. Namazikhah, S.; Shirani, R.; Mohseni, A.; Farsio, F. Dye leakage study: Comparing conventional and new techniques. J. Calif. Dent. Assoc. 2000, 28, 435-442. [PubMed]

355. Juhlin, J.J.; Walton, R.E.; Dorgan, J.S. Adaptation of Thermafil components to canal walls. J. Endod. 1993, 19, 130-135. [CrossRef]

356. Gutman, J.L.; Sounders, W.P.; Saunders, E.M.; Nguyen, L. An assessment of the plastic Thermafil obturation technique Part I, Radiographic evaluation of adaptation and placement. Int. Endod. J. 1993, 26, 173-178. [CrossRef]

357. Dobrzański, L.A.; Dobrzański, L.B.; Dobrzańska-Danikiewicz, A.D. Overview of conventional technologies using the powders of metals, their alloys and ceramics in Industry 4.0 stage. J. Achiev. Mater. Manuf. Eng. 2020, 98, 56-85. [CrossRef] 
358. Dobrzański, L.A. Role of materials design in maintenance engineering in the context of industry 4.0 idea. J. Achiev. Mater. Manuf. Eng. 2019, 96, 12-49. [CrossRef]

359. Dobrzański, L.A.; Dobrzańska-Danikiewicz, A.D. Applications of Laser Processing of Materials in Surface Engineering in the Industry 4.0 Stage of the Industrial Revolution. Mater. Perform. Charact. 2019, 8, 1091-1129. [CrossRef]

360. Dobrzański, L.A.; Dobrzańska-Danikiewicz, A.D. Why Are Carbon-Based Materials Important in Civilization Progress and Especially in the Industry 4.0 Stage of the Industrial Revolution. Mater. Perform. Charact. 2019, 8, 337-370. [CrossRef]

361. Dobrzański, L.A.; Dobrzański, L.B.; Dobrzańska-Danikiewicz, A.D.; Kraszewska, M. Manufacturing powders of metals, their alloys and ceramics and the importance of conventional and additive technologies for products manufacturing in Industry 4.0 stage. Arch. Mater. Sci. Eng. 2020, 102, 13-41. [CrossRef]

362. Hermann, M.; Pentek, T.; Otto, B. Design Principles for Industrie 4.0 Scenarios: A Literature Review; Technische Universität Dortmund: Dortmund, Germany, 2015.

363. Kagermann, H.; Wahlster, W.; Helbig, J. Recommendations for Implementing the Strategic Initiative INDUSTRIE 4.0: Final Report of the Industrie 4.0 Working Group; Federal Ministry of Education and Research: Bonn, Germany, 2013.

364. Rüßmann, M.; Lorenz, M.; Gerbert, P.; Waldner, M.; Justus, J.; Engel, P.; Harnisch, M. Industry 4.0: The Future of Productivity and Growth in Manufacturing Industries; Boston Consulting Group: Boston, MA, USA, 2015.

365. Kagermann, H. Chancen von Industrie 4.0 Nutzen. In: Industrie 4.0 in Produktion, Automatisierung und Logistik; Springer Fachmedien Wiesbaden: Wiesbaden, Germany, 2014; pp. 603-614.

366. Lee, J.; Kao, H.-A.; Yang, S. Service Innovation and Smart Analytics for Industry 4.0 and Big Data Environment. Proc. CIRP 2014, 16, 3-8. [CrossRef]

367. Jose, R.; Ramakrishna, S. Materials 4.0: Materials Big Data Enabled Materials Discovery. Appl. Mat. Today 2018, 10, 127-132. [CrossRef]

368. Brettel, M.; Friederichsen, N.; Keller, M.; Rosenberg, M. How Virtualization, Decentralization, and Network-Building Change the Manufacturing Landscape: An Industry 4.0 Perspective. Int. J. Mech. Aerospac. Indust. Mechatron. Manuf. Eng. 2014, 8, 37-44.

369. Tay, S.I.; Lee, T.C.; Hamid, N.A.A.; Ahmad, A.N.A. An Overview of Industry 4.0: Definition, Components, and Government Initiatives. J. Adv. Res. Dynamic Control Syst. 2018, 10, 1379-1387.

370. Xu, X. Machine Tool 4.0 for the New Era of Manufacturing. Int. J. Adv. Manuf. Techn. 2017, 92, 1893-1900. [CrossRef]

371. Sipsas, K.; Alexopoulos, K.; Xanthakis, V.; Chryssolouris, G. Collaborative Maintenance in Flow-Line Manufacturing Environments: An Industry 4.0 Approach. Proc. CIRP 2016, 55, 236-241. [CrossRef]

372. Hozdic, E. Smart Factory for Industry 4.0: A Review. Int. J. Modern Manuf. Tech. 2015, 7, 28-35.

373. Zhong, R.Y.; Xu, X.; Klotz, E.; Newman, S.T. Intelligent Manufacturing in the Context of Industry 4.0: A Review. Engineering 2017, 3, 616-630. [CrossRef]

374. Bahrin, M.A.K.; Othman, M.F.; Azli, N.H.N.; Talib, M.F. Industry 4.0: A Review on Industrial Automation and Robotic. J. Tekno 2016, 78, 137-143. [CrossRef]

375. Vaidya, S.; Ambad, P.; Bhosle, S. Industry 4.0-A Glimpse. Proc. Manuf. 2018, 20, 233-238. [CrossRef]

376. Lee, J.; Bagheri, B.; Kao, H.-A. A Cyber-Physical Systems Architecture for Industry 4.0-Based Manufacturing Systems. Manuf. Lett. 2015, 3, 18-23. [CrossRef]

377. Stock, T.; Seliger, G. Opportunities of Sustainable Manufacturing in Industry 4.0. Proc. CIRP 2016, 40, 536-541. [CrossRef]

378. Schumacher, A.; Erol, S.; Sihn, W. A Maturity Model for Assessing Industry 4.0 Readiness and Maturity of Manufacturing Enterprises. Proc. CIRP 2016, 52, 161-166. [CrossRef]

379. Kumar, K.; Zindani, D.; Davim, J.P. Industry 4.0: Developments towards the Fourth Industrial Revolution; Springer Nature: Singapore, 2019 .

380. Wang, S.; Wan, J.; Zhang, D.; Li, D.; Zhang, C. Towards Smart Factory for Industry 4.0: A Self-Organized Multi-Agent System with Big Data Based Feedback and Coordination. Comp. Netw. 2016, 101, 158-168. [CrossRef]

381. Mosterman, P.J.; Zander, J. Industry 4.0 as a Cyber-Physical System Study. Softw. Syst. Model. 2016, 15, 17-29. [CrossRef]

382. Almada-Lobo, F. The Industry 4.0 Revolution and the Future of Manufacturing Execution Systems (MES). J. Innov. Manag. 2015, 3, 16-21. [CrossRef]

383. Qin, J.; Liu, Y.; Grosvenor, R. A Categorical Framework of Manufacturing for Industry 4.0 and Beyond. Proc. CIRP 2016, 52, 173-178. [CrossRef]

384. Dobrzański, L.A.; Dobrzański, L.B. Approach to the Design and Manufacturing of Prosthetic Dental Restorations According to the Rules of Industry 4.0. Mater. Perform. Charact. 2020, 9, 394-476. [CrossRef]

385. Dobrzański, L.A.; Dobrzański, L.B. Dentistry 4.0 Concept in the Design and Manufacturing of Prosthetic Dental Restorations. Processes 2020, 8, 525. [CrossRef]

386. Dobrzański, L.A.; Dobrzański, L.B.; Achtelik-Franczak, A.; Dobrzańska, J. Application Solid Laser-Sintered or Machined Ti6Al4V Alloy in Manufacturing of Dental Implants and Dental Prosthetic Restorations According to Dentistry 4.0 Concept. Processes 2020, 8, 664. [CrossRef]

387. Dobrzański, L.A.; Dobrzański, L.B.; Dobrzańska-Danikiewicz, A.D. Manufacturing technologies thick-layer coatings on various substrates and manufacturing gradient materials using powders of metals, their alloys and ceramics. J. Achiev. Mater. Manuf. Eng. 2020, 99, 14-41. [CrossRef] 
388. Dobrzańska-Danikiewicz, A.D.; Dobrzański, L.A.; Szindler, M.; Achtelik-Franczak, A.; Dobrzański, L.B. Obróbka powierzchni materiałów mikroporowatych wytworzonych metodą selektywnego spiekania laserowego w celu uefektywnienia proliferacji żywych komórek. In Metalowe Materiały Mikroporowate i Lite do Zastosowań Medycznych i Stomatologicznych; Open Access Library VII(1); Dobrzański, L.A., Dobrzańska-Danikiewicz, A.D., Eds.; International OCSCO World Press: Gliwice, Poland, 2017; pp. 289-375.

389. Dobrzańska-Danikiewicz, A. The methodological fundaments of development state analysis of surface engineering technologies. J. Achiev. Mater. Manuf. Eng. 2010, 40, 203-210.

390. Dobrzańska-Danikiewicz, A.D.; Hajduczek, E.; Polok-Rubiniec, M.; Przybył, M.; Adamaszek, K. Evaluation of selected steel thermochemical treatment technologies using foresight methods. J. Achiev. Mater. Manuf. Eng. 2011, 46, 115-146.

391. Dobrzańska-Danikiewicz, A.D. The development perspectives of Physical Vapour Deposition technologies. J. Achiev. Mater. Manuf. Eng. 2012, 54, 103-109.

392. Dobrzańska-Danikiewicz, A.D. Metodologia Komputerowo Zintegrowanego Prognozowania Rozwoju Inżynierii Powierzchni Materiałów; In Open Access Library 1(7); Dobrzański, L.A., Ed.; International OCSCO World Press: Gliwice, Poland, 2012 ; pp. 1-289.

393. Dobrzańska-Danikiewicz, A.D. Ksiega Technologii Krytycznych Kształtowania Struktury i Własności Powierzchni Materiałów Inżynierskich; In Open Access Library 8(26); Dobrzański, L.A., Ed.; International OCSCO World Press: Gliwice, Poland, 2013; p. 1823.

394. Dobrzańska-Danikiewicz, A.D. (Ed.) Materials Surface Engineering Development Trends; Open Access Library 6; International OCSCO World Press: Gliwice, Poland, 2011; pp. 1-594.

395. Dobrzańska-Danikiewicz, A.D.; Dobrzański, L.A.; Sękala, A. Results of Technology Foresight in the Surface Engineering Area. Appl. Mech. Mater. 2014, 657, 916-920. [CrossRef]

396. Dobrzańska-Danikiewicz, A.D.; Dobrzański, L.A.; Mazurkiewicz, J.; Tomiczek, B.; Reimann, Ł. E-transfer of materials surface engineering e-foresight results. Arch. Mater. Sci. Eng. 2011, 52, 87-100.

397. Dobrzańska-Danikiewicz, A.D.; Tański, T.; Malara, S.; Domagała-Dubiel, J. Technology Foresight Results Concerning Laser Surface Treatment of Casting Magnesium Alloys. In New Features on Magnesium Alloys; Monteiro, W.A., Ed.; IntechOpen: Rijeka, Croatia, 2012; pp. 1-30. [CrossRef]

398. Dobrzańska-Danikiewicz, A.D. Foresight of Material Surface Engineering as a Tool Building a Knowledge-Based Economy. Mater. Sci. Forum 2012, 706-709, 2511-2516. [CrossRef]

399. Dobrzański, L.A.; Achtelik-Franczak, A. Struktura i własności tytanowych szkieletowych materiałów mikroporowatych wytworzonych metodą selektywnego spiekania laserowego do zastosowań w implantologii oraz medycynie regeneracyjnej. In Metalowe Materiały Mikroporowate i Lite do Zastosowań Medycznych i Stomatologicznych; Open Access Library VII(1); Dobrzański, L.A., Dobrzańska-Danikiewicz, A.D., Eds.; International OCSCO World Press: Gliwice, Poland, 2017; pp. 186-244.

400. Dobrzański, L.A. Effect of heat and surface treatment on the structure and properties of the Mg-Al-Zn-Mn casting alloys. In Magnesium and Its Alloys; Dobrzański, L.A., Totten, G.E., Bamberger, M., Eds.; CRC Press: Boca Raton, FL, USA, 2019 ; pp. 91-202.

401. Dobrzański, L.A.; Dobrzańska-Danikiewicz, A.D. Perspektywy i trendy rozwojowe inżynierii powierzchni materiałów. In Inżynieria Powierzchni Materiałów: Kompendium Wiedzy i Podręcznik Akademicki; Open Access Library VIII(1); Dobrzański, L.A., Ed.; International OCSCO World Press: Gliwice, Poland, 2018; pp. 89-157.

402. Salehrabi, R.; Rotstein, I. Endodontic treatment outcomes in a large patient population in the USA: An epidemiological study. J. Endod. 2004, 30, 846-850. [CrossRef]

403. Lazarski, M.P.; Walker, W.A.; Flores, C.M.; Schindler, W.G.; Hargreaves, K.M. Epidemiological evaluation of the outcomes of nonsurgical root canal treatment in a large cohort of insured dental patients. J. Endod. 2001, 27, 791-796. [CrossRef]

404. Chen, S.C.; Chueh, L.H.; Hsiao, C.K.; Tsai, M.Y.; Ho, S.C.; Chiang, C.P. An epidemiologic study of tooth retention after nonsurgical endodontic treatment in a large population in Taiwan. J. Endod. 2007, 33, 226-229. [CrossRef]

405. Meuwissen, R.; Eschen, S. Twenty years of endodontic treatment. J. Endod. 1983, 9, 390-393. [CrossRef]

406. Sunay, H.; Tanalp, J.; Dikbas, I.; Bayirli, G. Cross-sectional evaluation of the periapical status and quality of root canal treatment in a selected population of urban Turkish adults. Int. Endod. J. 2007, 40, 139-145. [CrossRef]

407. Jiménez-Pinzón, A.; Seguro-Egea, J.J.; Poyato-Ferrera, H.; Velasco-Ortega, E.; Rios-Santos, J.V. Prevalence of apical periodontitis and frequency of root fillednteeth in an adult Spanish population. Int. Endod. J. 2004, 37, 167-173. [CrossRef]

408. Loftus, J.J.; Keating, A.P.; McCartan, B.E. Periapical status and quality of endodontic treatment in an adult Irish population. Int. Endod. J. 2005, 38, 81-86. [CrossRef]

409. Peciuliene, V.; Rimkuviene, J.; Maneliene, R.; Iranauskaite, D. Apical periodontitis in root filled teeth associated with the quality of root fillings. Stomatologija 2006, 8, 122-126. [PubMed]

410. De Moor, R.J.G.; Hommez, G.M.G.; de Boever, J.G.; Delmé, K.I.M.; Martens, G.E.I. Periapical health related to the quality of root canal treatment in a Belgian population. Int. Endod. J. 2000, 33, 113-120. [CrossRef] [PubMed]

411. Da Silva, K.; Lam, J.M.Y.; Wu, N.; Duckmanton, P. Cross-sectional study of endodontic treatment in an Australian population. Aust. Endod. J. 2009, 35, 140-146. [CrossRef] [PubMed]

412. Terças, A.G.; de Oliveira, A.E.F.; Lopes, F.F.; Filho, E.M.M. Radiographic study of the prevalence of apical periodontitis and endodontic treatment in the adult population of São Luís, MA, Brazil. J. Appl. Oral. Sci. 2006, 14, 183-187. [CrossRef]

413. Georgopoulou, M.K.; Spanaki-Voreadi, A.P.; Pantazis, N.; Kontakiotis, E.G. Frequency and distribution of root filled teeth and apical periodontitis in a Greek population. Int. Endod. J. 2005, 38, 105-111. [CrossRef] [PubMed] 
414. Kirkevang, L.L.; Hörsted-Bindslev, P.; Ostravik, D.; Wenzel, A. Frequency and distribution of endodontically treated teeth and apical periodontitis in an urban Danish population. Int. Endod. J. 2001, 34, 198-205. [CrossRef]

415. Tsuneishi, M.; Yamamoto, T.; Yamanaka, R.; Tamaki, N.; Sakamoto, T.; Tsuji, K.; Watanabe, T. Radiographic evaluation of periapical status and prevalence of endodontic treatment in an adult Japanese population. Oral Surg. Oral Med. Oral Pathol. Oral Radiol. Endod. 2005, 100, 631-635. [CrossRef] [PubMed]

416. Gharib, S.R.; Tordik, P.A.; Imamura, G.M.; Bagiński, T.A.; Goodell, G.G. A confocal laser scanning microscope investigation of the Epiphany obturation system. J. Endod. 2007, 33, 957-961. [CrossRef] [PubMed]

417. Kontakiotis, E.; Chaniotis, A.; Georgopoulou, M. Fluid filtration evaluation of 3 obturation techniques. Quint. Int. 2007, $38,410-416$.

418. Dziedzic, A.; Turski, R.; Werszner, R.; Wojdyło, M. Ocena in vitro szczelności wypełnień kanałów korzeniowych systemem EndoREZ z wykorzystaniem ćwieków gutaperkowych o zwiększonym stopniu zbieżności. Mag. Stomatol. $2005,15,38-41$.

419. Vogt, B.F.; Xavier, C.B.; Demarco, F.F.; Padilha, M.S. Dentin penetrability evaluation of three different dyes in root-end cavities filled with mineral trioxide aggregate (MTA). Braz. Oral Res. 2006, 20, 132-136. [CrossRef]

420. Gencoglu, N.; Garip, Y.; Bas, M.; Samani, S. Comparison of different gutta-percha Root filling techniques: Thermafil, Quick-fill, System B and Lateran condensation. Oral Surg. Oral Med. Oral Pathol. Oral Radiol. Endod. 2002, 93, 333-336. [CrossRef]

421. Sliva, G.; da Silva, E.J.N.; da Silva, J.M.; Andrande-Junior, C.V.; Ferraz, C.C.R. Sealing ability promoted by three different endodontic sealers. Iran. Endod. J. 2011, 6, 86-89. [CrossRef]

422. Mannocci, F.; Innocenti, M.; Ferrari, M. Stereomicroscopic and scanning electron microscopic study of roots obturated with vertically condensed gutta-percha, epoxy resin cement and dentin bonding agent. J. Endod. 1998, 24, 397-400. [CrossRef]

423. Mannocci, F.; Innocenti, M.; Bertelli, E.; Ferrari, M. Dye leakage and SEM study of roots obturated with Thermafill and dentin bonding agent. Endod. Dent. Traumatol. 1999, 15, 60-64. [CrossRef]

424. Serafino, C.; Gallina, G.; Cumbo, E.; Ferrari, M. Surface debris of canal walls after post space preparation in endodontically treated teeth: A scanning electron microscopic study. Oral Surg. Oral Med. Oral Pathol. Oral Radiol. Endod. 2004, 97, $381-387$. [CrossRef] [PubMed]

425. Bołtacz-Rzepkowska, E.; Pawlicka, H.; Klimek, L. Przyleganie wypełnień do ścian kanału korzeniowego wykonanych różnymi technikami-badania w mikroskopie skaningowym. Czas. Stomatol. 2003, 56, 163-168.

426. Szkodny, K.; Postek-Stefańska, L.; Michalewicz, M.; Mangold, D.; Koziarz, A. Porównanie szczelności brzeżnej wypełnień kanałowych wykonanych metoda kondensacji bocznej i z użyciem Soft-Core. Badanie w SEM. Mag. Stomatol. 2002, 12, 68-72.

427. Dobrzański, L.A. Podstawy Nauki o Materiatach i Metaloznawstwo; WNT: Warszawa, Poland, 2002; pp. 1-1500.

428. Dobrzańska, J.; Dobrzański, L.B.; Dobrzański, L.A.; Gołombek, K.; Dobrzańska-Danikiewicz, A.D. Strengths, weaknesses, opportunities, and threats analysis of the resilon as filling material in endodontics. Appl. Sci. 2021, 11, 1-58. 